National Water Census and National Streamflow Information Program

\title{
Influence of Septic Systems on Stream Base Flow in the Apalachicola-Chattahoochee-Flint River Basin Near Metropolitan Atlanta, Georgia, 2012
}

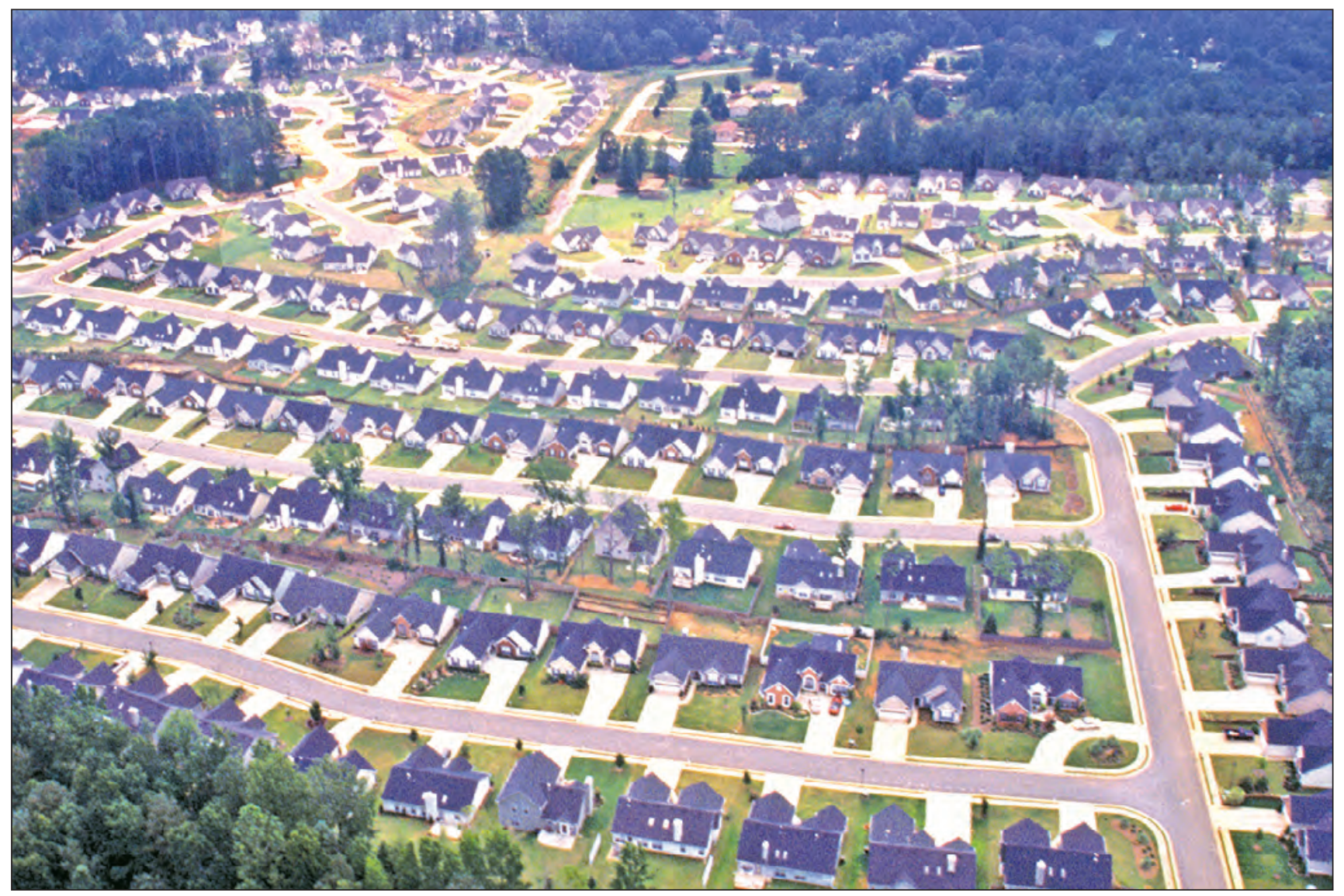

Scientific Investigations Report 2014-5144 
Cover. Suburban area of Metropolitan Atlanta, Georgia (photograph by Daniel J. Hippe, USGS). 


\section{Influence of Septic Systems on Stream Base Flow in the Apalachicola-Chattahoochee-Flint River Basin Near Metropolitan Atlanta, Georgia, 2012}

John S. Clarke and Jaime A. Painter

National Water Census and National Streamflow Information Program

Scientific Investigations Report 2014-5144 


\title{
U.S. Department of the Interior SALLY JEWELL, Secretary
}

\section{U.S. Geological Survey Suzette M. Kimball, Acting Director}

\author{
U.S. Geological Survey, Reston, Virginia: 2014
}

For more information on the USGS - the Federal source for science about the Earth, its natural and living resources, natural hazards, and the environment—visit http://www.usgs.gov or call 1-888-ASK-USGS.

For an overview of USGS information products, including maps, imagery, and publications, visit http://Www.usgs.gov/pubprod

To order this and other USGS information products, visit http://store.usgs.gov

Any use of trade, product, or firm names is for descriptive purposes only and does not imply endorsement by the U.S. Government.

Although this report is in the public domain, permission must be secured from the individual copyright owners to reproduce any copyrighted materials contained within this report.

Suggested citation:

Clarke, J.S., and Painter, J.A., 2014, Influence of septic systems on stream base flow in the ApalachicolaChattahoochee-Flint River Basin near Metropolitan Atlanta, Georgia, 2012: U.S. Geological Survey Scientific Investigations Report 2014-5144, 68 p., http://dx.doi.org/10.3133/sir20145144.

ISSN $2328-0328$ (online) 


\section{Contents}

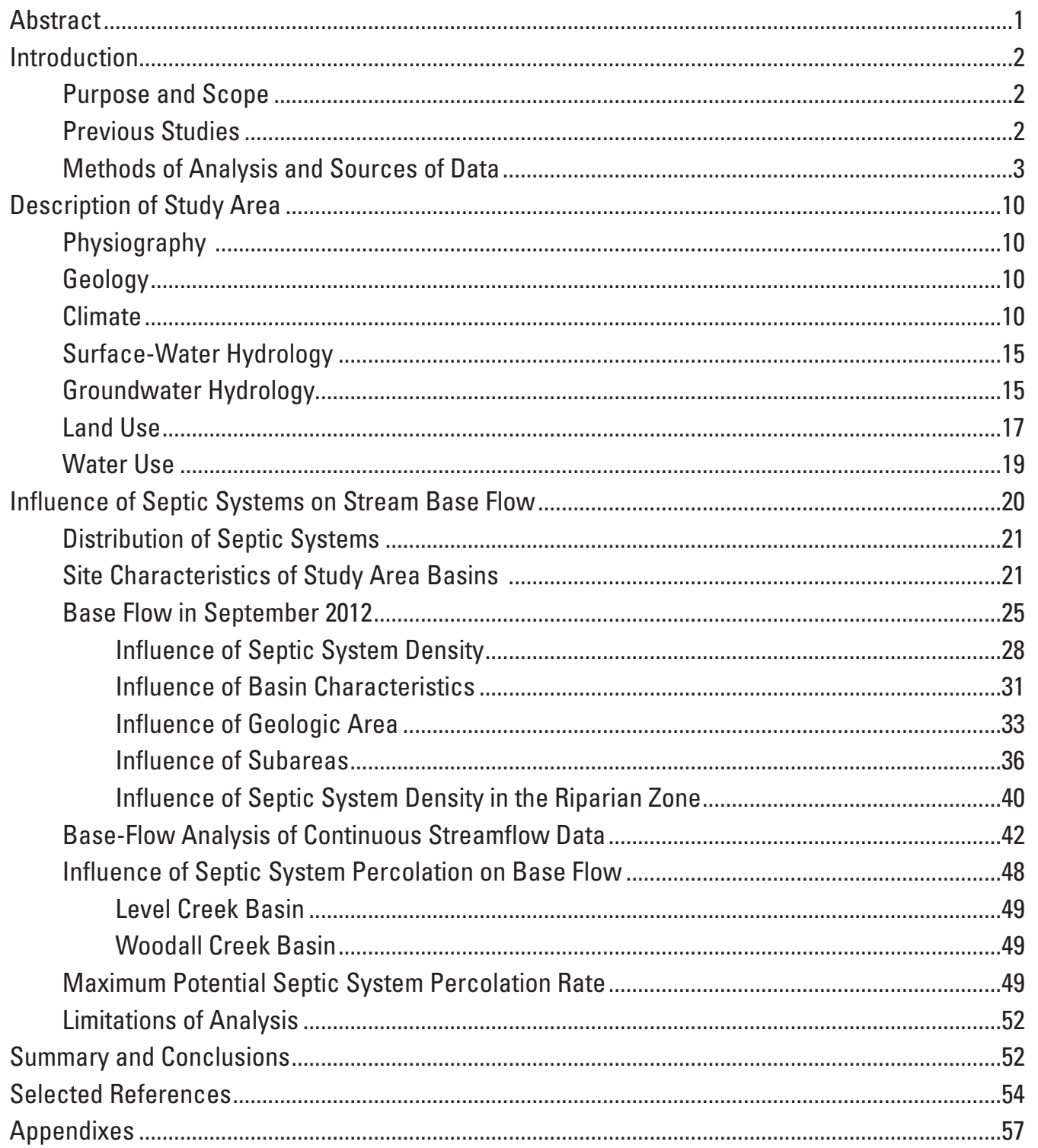




\section{Figures}

1. Maps showing location of Metropolitan Atlanta, Georgia, study area and data-collection sites...

2. Flowchart showing procedure for evaluating basins with high and low density of septic systems

3. Map showing physiographic provinces and districts of the ApalachicolaChattahoochee-Flint River Basin.

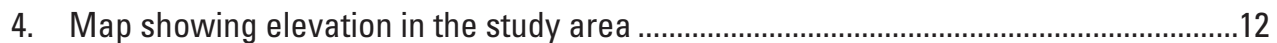

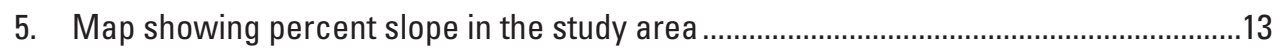

6. Map showing geologic areas of northern Georgia .......................................................14

7. Graphs showing stream discharge at USGS site 02334578 Level Creek at Suwannee Dam Creek near Suwannee, GA, and USGS site 02336313 Woodall Creek at Defoors Ferry Road, at Atlanta, GA, September 3-14, 2012.

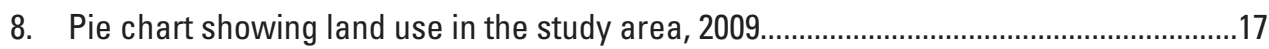

9. Map showing percentage of impervious area in the study area, 2006 ...........................18

10. Graph showing average annual surface-water withdrawals and return flows within the upper and middle Chattahoochee, upper Flint, and ApalachicolaChattahoochee-Flint River Basins in the study area, 2010...

11. Conceptual diagram of groundwater flow in the vicinity of septic systems, groundwater divides, and streams during dry hydrologic conditions .............................20

12. Map showing septic system density in study area, 2012 ..............................................22

13. Graph showing land-use characteristics for basins with high and low density of septic systems in the study area, 2009

14. Boxplots showing drainage area, impervious area, and topographic and soil characteristics of basins with high and low density of septic systems in the study area

15. Graphs showing base-flow yield and selected water-quality parameters in the study area, September 10-13, 2012.

16. Map showing intensity of drought in Georgia, September 11, 2012.

17. Graphs showing daily total rainfall, potential evapotranspiration, and net precipitation at Georgia Environmental Monitoring Network sites at Gainesville, Atlanta, and Roopville, September 2-14, 2012

18. Boxplots showing base-flow yield and selected water-quality parameters of basins with high and low density of septic systems in the study area, September 10-13, 2012.

19. Graph showing base-flow yield and septic system density for basins with high and low density of septic systems in the study area, September 10-13, 2012

20. Graph showing specific conductance and septic system density for basins with high and low density of septic systems in the study area, September 10-13, 2012.......29 
21. Graphs showing predicted and observed base-flow yield and residuals for multiple linear regression model.....

22. Graph showing base-flow yield by geologic area, September $10-13,2012 \ldots \ldots \ldots \ldots \ldots \ldots . . . .33$

23. Boxplots showing base-flow yield, drainage area, impervious area, and topographic and soil characteristics of basins by geologic area

24. Boxplots showing base-flow yield and specific conductance by geologic area and septic system density..... .35

25. Graph showing base-flow yield by subarea, September 10-13, 2012

26. Boxplots showing base-flow yield, drainage area, impervious area, and topographic and soil characteristics of basins by subarea

27. Boxplots showing base-flow yield and specific conductance by subarea and septic system density...

28. Boxplots showing drainage area, impervious area, and topographic and soil characteristics within the 45-meter buffer by septic system density

29. Boxplots showing base-flow yield and specific conductance within the 45-meter buffer zone by septic system density

30. Graphs showing base-flow yield and basin characteristics of USGS site 02334578 Level Creek at Suwannee Dam Creek near Suwannee, GA, and USGS site 02336313 Woodall Creek at Defoors Ferry Road, at Atlanta, GA

31. Map showing drainage area and location of USGS site 02334578, Level Creek at Suwanee Dam Road near Suwanee, GA.

32. Map showing drainage area and location of USGS site 02336313 , Woodall Creek at Defoors Ferry Road, at Atlanta, GA.

33. Graphs showing base-flow separation using the local-minimum method for daily streamflow during January 2011 through September 2012 at USGS site 02334578 Level Creek at Suwannee Dam Creek near Suwannee, GA, and USGS site 02336313 Woodall Creek at Defoors Ferry Road, at Atlanta, GA

34. Graphs showing percentage contribution of base flow to streamflow during January 2011 through September 2012 at USGS sites 02334578 and 02336313

35. Graph showing base flow contributed by maximum potential septic system percolation and other contributors, USGS site 02334578 Level Creek at Suwannee Dam Creek near Suwannee, GA, January 2011-September 2012.

36. Graph showing base flow contributed by maximum potential septic system percolation and other contributors, USGS site 02336313 Woodall Creek at Defoors Ferry Road, at Atlanta, GA, January 2011-September 2012

37. Map showing maximum estimated potential septic system percolation rate in the study area

38. Graphs showing daily mean streamflow at USGS site 02338000 Chattahoochee River near Whitesburg, GA, and USGS site 02344350 Flint River near Lovejoy, GA, and maximum potential contribution from septic system percolation, January 2011-September 2012 


\section{Tables}

1. Sources of basin characteristic and population data ........................................................

2. Sources of information and procedures used to estimate septic system locations

3. Statistical summary of base-flow yield, and selected water-quality parameters, September 10-13, 2012

4. Statistics for multiple linear regression model comparing base-flow yield to selected basin characteristics, September 10-13, 2012.

5. Statistical summary of base-flow yield and specific conductance by geologic area, September 10-13, 2012 .

6. Statistical summary of base-flow yield and specific conductance by subarea, September 10-13, 2012

7. Statistical summary of base-flow yield within 45 -meter buffer zone for areas with high and low density of septic systems, September 10-13, 2012

8. Summary of streamflow, estimated base flow, and base-flow yield during January 2011 through September 2012 at sites 02334578 and 02336313

9. Average daily single family residential water use, 2009

\section{Conversion Factors and Datums}

\begin{tabular}{|c|c|c|}
\hline Multiply & By & To obtain \\
\hline \multicolumn{3}{|c|}{ Length } \\
\hline inch & 2.54 & centimeter $(\mathrm{cm})$ \\
\hline inch & 25.4 & millimeter (mm) \\
\hline foot (ft) & 0.3048 & meter $(\mathrm{m})$ \\
\hline mile (mi) & 1.609 & kilometer (km) \\
\hline \multicolumn{3}{|c|}{ Area } \\
\hline acre & 4,047 & square meter $\left(\mathrm{m}^{2}\right)$ \\
\hline acre & 0.4047 & hectare (ha) \\
\hline acre & 0.4047 & square hectometer $\left(\mathrm{hm}^{2}\right)$ \\
\hline acre & 0.004047 & square kilometer $\left(\mathrm{km}^{2}\right)$ \\
\hline square mile $\left(\mathrm{mi}^{2}\right)$ & 259.0 & hectare (ha) \\
\hline square mile $\left(\mathrm{mi}^{2}\right)$ & 2.590 & square kilometer $\left(\mathrm{km}^{2}\right)$ \\
\hline \multicolumn{3}{|c|}{ Flow rate } \\
\hline cubic foot per second $\left(\mathrm{ft}^{3} / \mathrm{s}\right)$ & 0.02832 & cubic meter per second $\left(\mathrm{m}^{3} / \mathrm{s}\right)$ \\
\hline $\begin{array}{l}\text { cubic foot per second per square } \\
\text { mile }\left[\left(\mathrm{ft}^{3} / \mathrm{s}\right) / \mathrm{mi}^{2}\right]\end{array}$ & 0.01093 & $\begin{array}{l}\text { cubic meter per second per square } \\
\text { kilometer }\left[\left(\mathrm{m}^{3} / \mathrm{s}\right) / \mathrm{km}^{2}\right]\end{array}$ \\
\hline gallon per day (gal/d) & 0.003785 & cubic meter per day $\left(\mathrm{m}^{3} / \mathrm{d}\right)$ \\
\hline million gallons per day (Mgal/d) & 0.04381 & cubic meter per second $\left(\mathrm{m}^{3} / \mathrm{s}\right)$ \\
\hline \multicolumn{3}{|c|}{ Potential evapotranspiration } \\
\hline inch per day (in/d) & 25.4 & millimeter per day $(\mathrm{mm} / \mathrm{d})$ \\
\hline
\end{tabular}


Temperature in degrees Celsius $\left({ }^{\circ} \mathrm{C}\right)$ may be converted to degrees Fahrenheit $\left({ }^{\circ} \mathrm{F}\right)$ as follows:

$$
{ }^{\circ} \mathrm{F}=\left(1.8 \times{ }^{\circ} \mathrm{C}\right)+32
$$

Temperature in degrees Fahrenheit $\left({ }^{\circ} \mathrm{F}\right)$ may be converted to degrees Celsius $\left({ }^{\circ} \mathrm{C}\right)$ as follows:

$$
{ }^{\circ} \mathrm{C}=\left({ }^{\circ} \mathrm{F}-32\right) / 1.8
$$

Vertical coordinate information is referenced to North American Vertical Datum of 1988 (NAVD 88).

Horizontal coordinate information is referenced to North American Datum of 1983 (NAD 83).

Elevation, as used in this report, refers to distance above the vertical datum.

Specific conductance is given in microsiemens per centimeter at 25 degrees Celsius $\left(\mu \mathrm{S} / \mathrm{cm}\right.$ at $\left.25^{\circ} \mathrm{C}\right)$.

Concentrations of chemical constituents in water are given in milligrams per liter (mg/L).

\section{Abbreviations}

$\begin{array}{ll}\text { ACF } & \text { Apalachicola-Chattahoochee-Flint } \\ \text { GIS } & \text { geographic information system } \\ \text { HDS } & \text { high density of septic systems } \\ \text { LDS } & \text { low density of septic systems } \\ \text { NED } & \text { National Elevation Dataset } \\ \text { NLCD } & \text { National Land Cover Database } \\ \text { PET } & \text { potential evapotranspiration } \\ \text { STATSGO } & \text { State Soil Geographic dataset } \\ \text { USGS } & \text { U.S. Geological Survey }\end{array}$




\section{Acknowledgments}

The authors appreciate the assistance of the various water and sewer utilities that provided information on septic tank locations and (or) information about water and sewer bills that were used to derive septic system locations. Calvin Johnson, U.S. Geological Survey (USGS), helped compile septic system information and data layers for the geographic information system (GIS) database developed for this study. Steve Lawrence, USGS, provided assistance in the computation of Wilcoxon rank-sum statistics and water withdrawal and discharge from major streams. Debbie Warner Gordon, USGS, provided hydrograph separation analysis at two sites. Chris Smith, USGS, coordinated field work activities during the low-flow synoptic event completed in September 2012. Tony Gotvald, USGS, provided an assessment of the accuracy of streamflow measurements collected during September 2012. 


\title{
Influence of Septic Systems on Stream Base Flow in the Apalachicola-Chattahoochee-Flint River Basin Near Metropolitan Atlanta, Georgia, 2012
}

\author{
John S. Clarke and Jaime A. Painter
}

\section{Abstract}

Septic systems were identified at 241,733 locations in a 2,539-square-mile $\left(\mathrm{mi}^{2}\right)$ study area that includes all or parts of 12 counties in the Metropolitan Atlanta, Georgia, area. Septic system percolation may locally be an important component of streamflow in small drainage basins where it augments natural groundwater recharge, especially during extreme low-flow conditions. The amount of groundwater reaching streams depends on how much is intercepted by plants or infiltrates to deeper parts of the groundwater system that flows beyond a basin divide and does not discharge into streams within a basin.

The potential maximum percolation from septic systems in the study area is 62 cubic feet per second $\left(\mathrm{ft}^{3} / \mathrm{s}\right)$, of which $52 \mathrm{ft}^{3} / \mathrm{s}$ is in the Chattahoochee River Basin and $10 \mathrm{ft}^{3} / \mathrm{s}$ is in the Flint River Basin. These maximum percolation rates represent 0.4 to 5.7 percent of daily mean streamflow during the 2011-12 period at the farthest downstream gaging site (station 02338000) on the Chattahoochee River, and 0.5 to 179 percent of daily mean streamflow at the farthest downstream gaging site on the Flint River (02344350).

To determine the difference in base flow between basins having different septic system densities, hydrograph separation analysis was completed using daily mean streamflow data at streamgaging stations at Level Creek (site 02334578), with a drainage basin having relatively high septic system density of 101 systems per square mile, and Woodall Creek (site 02336313 ), with a drainage basin having relatively low septic system density of 18 systems per square mile. Results indicated that base-flow yield during 2011-12 was higher at the Level Creek site, with a median of 0.47 cubic feet per second per square mile $\left(\left[\mathrm{ft}^{3} / \mathrm{s}\right] / \mathrm{mi}^{2}\right)$, compared to a median of $0.16\left(\mathrm{ft}^{3} / \mathrm{s}\right) / \mathrm{mi}^{2}$, at the Woodall Creek site. At the less urbanized Level Creek site, there are 515 septic systems with a daily maximum percolation rate of $0.14 \mathrm{ft}^{3} / \mathrm{s}$, accounting for 11 percent of the base flow in September 2012. At the more urban Woodall Creek site, there are 50 septic systems with an average daily maximum percolation rate of $0.0097 \mathrm{ft}^{3} / \mathrm{s}$, accounting for 5 percent of base flow in September 2012.

Streamflow measurements at 133 small drainage basins (less than $5 \mathrm{mi}^{2}$ in area) during September 2012 indicated no statistically significant difference in streamflow or specific conductance between basins having high and low density of septic systems (HDS and LDS, respectively). The median base-flow yield was $0.04\left(\mathrm{ft}^{3} / \mathrm{s}\right) / \mathrm{mi}^{2}$ for HDS sites, ranging from 0 to $0.52\left(\mathrm{ft}^{3} / \mathrm{s}\right) / \mathrm{mi}^{2}$, and $0.10\left(\mathrm{ft}^{3} / \mathrm{s}\right) / \mathrm{mi}^{2}$ for LDS sites, ranging from 0 to $0.49\left(\mathrm{ft}^{3} / \mathrm{s}\right) / \mathrm{mi}^{2}$. A Wilcoxon rank-sum test indicated the median base-flow yields for HDS and LDS sites were not statistically different, with a p-value of 0.345 .

Because of the large size of the study area and associated variations in basin characteristics, data collected in September 2012 were also evaluated on the basis of the basins physical characteristics in an attempt to reduce or eliminate other basin characteristics that might affect base flow. Basins were evaluated based on geologic area, four geographic subareas, and 45 -meter ( $147.6 \mathrm{ft})$ buffer zone; there were no statistically significant differences between median base-flow yield for HDS and LDS basins. It is probable that detection of the contribution from septic system percolation in base flow at many of the sites visited in September 2012 was obscured by a combination of the limitations of measurement accuracy and evapotranspiration. Detection of septic system percolation may also have been complicated by leaky water and sewer mains, which may have resulted in higher streamflows in LDS basins relative to HDS basins. 


\section{Introduction}

In 2010, the U.S. Geological Survey (USGS) launched the National Water Census as authorized by sec. 9508 of the Omnibus Public Land Management Act of 2009 (42 USC 10368), which calls for the establishment of a "national water availability and use assessment program." As part of the National Water Census, the USGS is studying water availability and use in various focus areas across the country, including the Apalachicola-Chattahoochee-Flint (ACF) River Basin in Alabama, Florida, and Georgia (fig. 1). Knowing how much water is withdrawn, consumed, lost, transferred, and disposed of within a river basin is necessary for effective resource management (Fanning, 2007).

Assessment of water budgets that account for inputs to, outputs from, and changes in the amount of water within a river basin are an important part of the USGS focus-area studies completed for the National Water Census. This study focuses on water budgets for surface water in the ACF River Basin. The basic components of the water budget are precipitation, evapotranspiration, surface-water and groundwater flow into and out of the basin, changes in surface-water and groundwater storage, water withdrawals, and interbasin transfer.

The USGS defines consumptive water use as water that is evaporated, transpired, incorporated into a product or a crop, consumed by humans or animals, or otherwise removed from the immediate environment and is therefore not immediately available for reuse (Hutson and others, 2004). Net water use represents the difference between all water withdrawn from a river basin and all water returned to the basin (discharge) within a given water-use timeframe, and is thus the net effect of all consumptive use, withdrawals, and discharges (Fanning, 2007). The net-use calculation includes interbasin transfers; groundwater discharged from supply systems to streams (for example, withdrawn from a well and discharged into a stream); and groundwater discharged to streams from groundwater storage, which includes natural recharge, pipe leakage, and septic system percolation. The contribution to stream base flow by septic systems has become an important watermanagement issue in Metropolitan Atlanta, Georgia, because of growing demands for limited water resources (Georgia Environmental Protection Division, 2008). In particular, knowing the amount of water percolating from septic systems that returns to streams within a river basin will enable a more accurate accounting of water resources.

Landers and Ankcorn (2008) reported an estimated 26 percent of the single-family housing units in Metropolitan Atlanta were served by septic systems in 2004 (U.S. Department of Housing and Urban Development and U.S. Census Bureau, 2005); a similar evaluation of data for 2010 indicated the percentage was about 27 percent (U.S. Department of Housing and Urban Development and U.S. Census Bureau, 2010). Water percolating from septic systems into groundwater and ultimately discharged into streams may be an important component of the water budget in small watersheds, which predominate much of the Metropolitan Atlanta study area. To quantify the effect of septic systems on stream base flow, the USGS completed a study in a 12-county area within the upper part of the ACF River Basin during 2012.

\section{Purpose and Scope}

The purpose of this report is to quantify the effect of septic systems on stream base flow in a 12-county area within the upper part of the ACF River Basin during 2012. To fulfill this objective, the following information is presented herein:

- Synoptic streamflow measurements at 133 ungaged sites and field water-quality measurements at 94 sites during the low-flow period September 10-13, 2012;

- Compiled locations of septic systems, and land use, geologic, soil, and topographic characteristics in the study area;

- Statistical evaluations of differences in streamflow in basins having high and low density of septic systems;

- Analyses of water budgets in two small watershedsone with a relatively high density of septic systems and one with a low density of septic systemsincluding analysis of existing continuous streamflow records using hydrograph separation techniques;

- Estimates of maximum potential septic system percolation rates for the study area; and

- Analysis of the potential contribution of septic system percolation to daily mean streamflow at sites representing the most downstream streamgage locations in the Chattahoochee and Flint River Basins in the study area.

\section{Previous Studies}

Landers and Ankcorn (2008) completed a reconnaissance-level investigation during October 2007 comparing base flow in 24 basins having low and high densities of septic systems in southeastern Gwinnett County, Ga., about 5 to 10 miles southeast of the ACF River Basin. An arbitrary threshold of less than 100 systems per square mile (systems $/ \mathrm{mi}^{2}$ ) was set for low density (LDS) watersheds and greater than $200 \mathrm{systems} / \mathrm{mi}^{2}$ for high density (HDS) watersheds. Spatial data were analyzed to characterize a variety of basin characteristics, including drainage area, slope, 
impervious area, and septic system density. The study area was selected to ensure that geologic setting was consistent among all basins. The Landers and Ankcorn (2008) study indicated that mean base-flow yield, normalized for drainage area, was 90 percent greater in HDS watersheds than in LDS watersheds. Specific conductance of base flow was generally higher in the HDS watersheds than in the LDS watersheds.

Several earlier studies documented the relation between stream base flow and septic systems. On Long Island, New York, Simmons and Reynolds (1982) analyzed long-term streamflow records in two urban watersheds that indicated a 60-percent decrease in annual base flow coincident with increased imperviousness and a transition from septic systems to centralized sanitary sewer systems. Most of this decrease was attributed to the elimination of septic systems, because the baseflow decline in two nearby watersheds that were increasingly urbanized but unsewered was only 10 percent during the same period. Also in New York, Burns and others (2005) reported increased base flow associated with higher residential density in three small basins. Elevated nitrate and sulfate concentrations in the three basins indicated that the increase was attributable to septic system discharges, and the increased base flow was equivalent to the estimated flow into septic systems.

The Metropolitan North Georgia Water Planning District (2006) provided an overview of septic system management practices and usage that included a survey of county environmental health officers responsible for septic management in each of the 16 counties of the district. The survey yielded information about the current usage of septic systems, their ages, and failure rates and causes by county.

LaFontaine (2009) described differences in streamflow characteristics between rural, suburban, and urban basins based on data collected at 12 streamgaging sites in the ACF River Basin near Atlanta from October 2003 through September 2006. The study included the development of a base-flow index based on hydrograph separation. The base-flow index (Wahl and Wahl, 1995) is the total volume of base flow divided by the total volume of runoff during a specified period, providing an indication of the percentage of streamflow provided by base flow. The study found that the base-flow index was highest in rural basins, followed by suburban and urban basins. Higher percentages of impervious area in suburban and urban settings likely inhibits the infiltration of precipitation into groundwater and accounts for the lower base-flow indices in those areas.

\section{Methods of Analysis and Sources of Data}

To quantify base flow in the northern ACF River Basin, small watersheds were selected for evaluation on the basis of basin size (less than 5 square mile $\left[\mathrm{mi}^{2}\right]$ drainage area) and accessibility for streamflow measurements. Once sites having suitable drainage area and accessibility were identified, a subset of 133 sites were selected to ensure a uniform distribution throughout the study area. A geographic information system (GIS) was used to delineate a drainage basin for each measurement point location and the following characteristics were determined: drainage area, minimum, maximum and mean basin elevation, mean percent basin slope, land use type, percentage of basin imperviousness, water-table and bedrock depth, soil permeability, number of septic systems, population size, and estimated average water use per household. Sources of basin characteristic and population data are listed in table 1 .

Locations of septic systems were acquired from the GIS, planning, or water departments of individual counties or municipal governments and were assimilated into a consistent format in the project database (table 2). Some of the data were provided as point locations in geospatial datasets and required no modifications for incorporation into the study database. One county provided septic systems as locations in the form of a street address. This address was georeferenced and converted to a point spatial dataset. In some areas that lacked specific information about the existence of septic systems, land-parcel data attributes were used to delineate septic system locations. If a parcel had at least one bathroom that was more than 100 feet (ft) away from a sewer line, then it was considered served by a septic system.

The majority of septic system locations were derived from billing records. Billing addresses served by water but not sewer were considered served by septic systems. These addresses were geo-referenced and linked to the corresponding parcel polygon data. The centroid of the parcel polygon that shared the address of a septic system user was designated as the location of the septic system.

In some counties, multiple sources of data were provided by municipalities or water utilities to determine the locations of septic systems. A cross-check was completed to ensure there was no overlap of these data to avoid double-counting of septic systems. Location information for septic systems were assembled into a single-feature digital dataset, by county, consisting of 241,733 sites located within the ACF River Basin.

Stream hydrography was derived from the USGS National Hydrography Dataset at a resolution of 1:24,000 (http://nhd.usgs.gov/). Drainage basin boundaries for each measurement point are needed as a first step in determining basin characteristics. Basin boundaries were delineated using a National Elevation Dataset (NED) digital elevation model at a 10-meter (m) horizontal resolution (U.S. Geological Survey, 2009). The watershed processing tool for the ArcHydro data model uses measurement locations and the conditioned elevation data to delineate the drainage area upstream of the measurement point. Using the polygonal boundaries generated for each basin, a variety of basin characteristics were determined (table 1). 


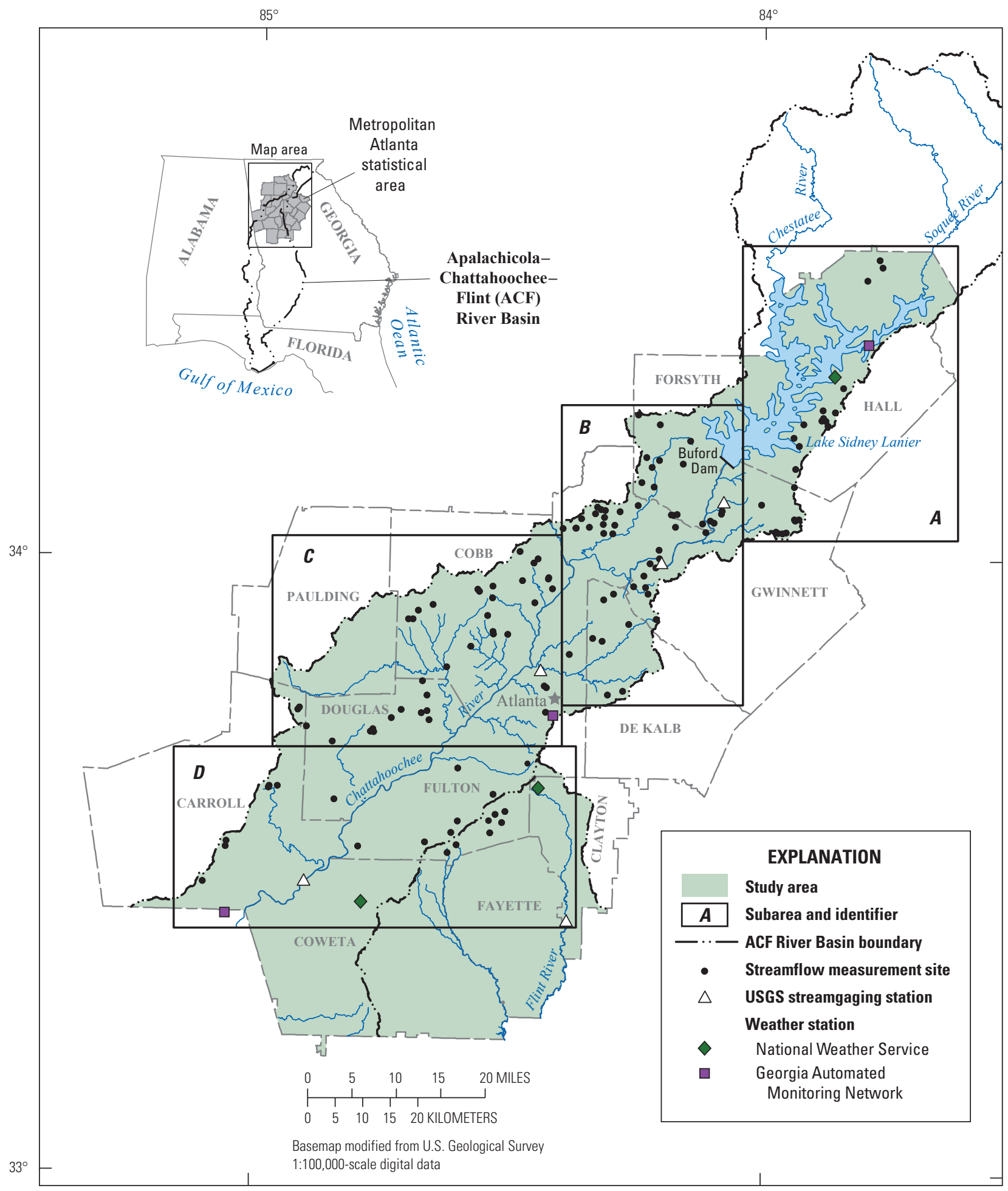

Figure 1 (pages 4 and 5). Location of Metropolitan Atlanta, Georgia, study area and data-collection sites. See facing page for enlargement of subareas $A-D$. 

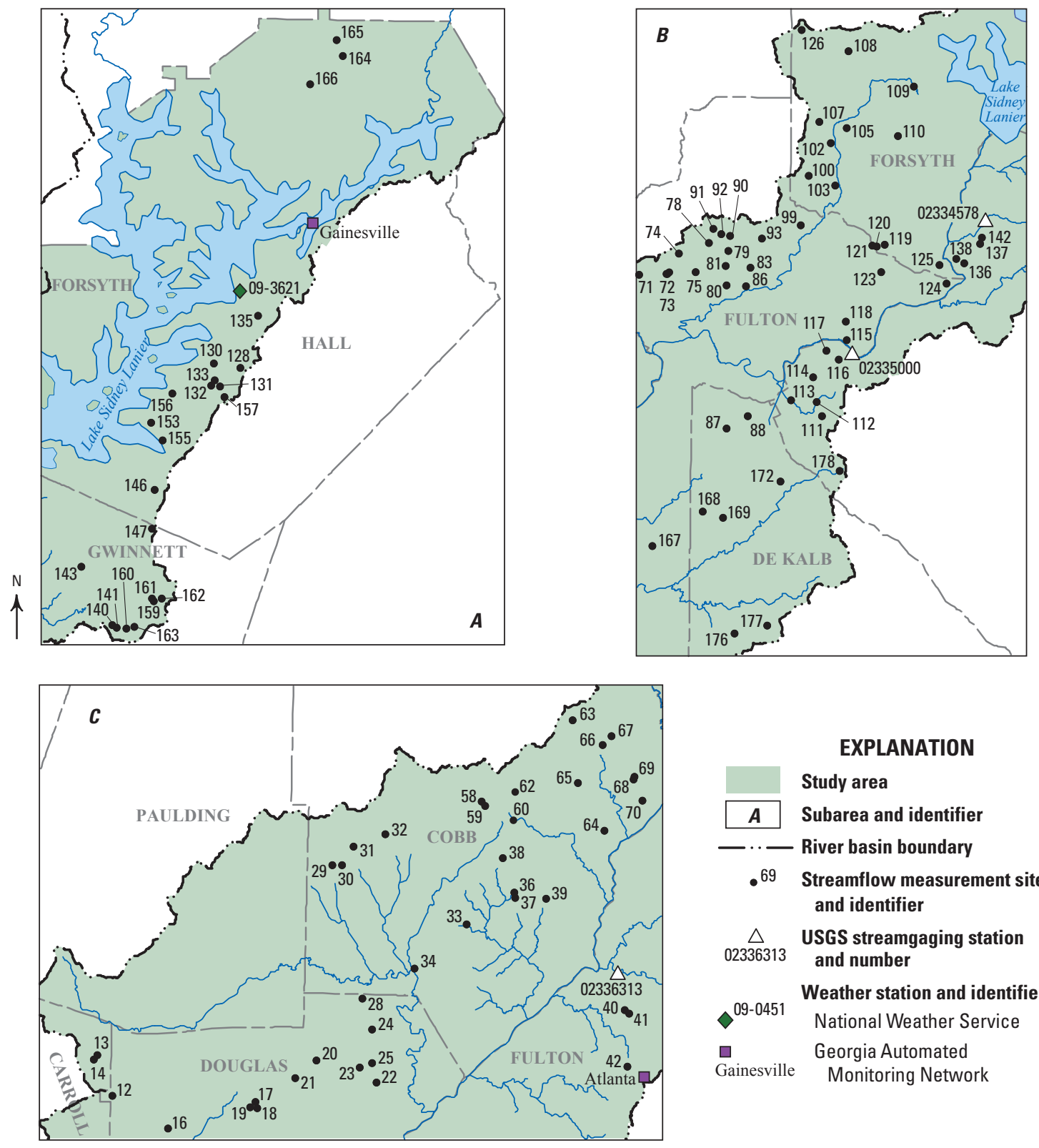

\section{EXPLANATION}

\section{Study area}

Subarea and identifier

River basin boundary

-69 Streamflow measurement site and identifier

$\triangle \quad$ USGS streamgaging station 02336313 and number

09-0451 Weather station and identifier National Weather Service

a Georgia Automated

Gainesville Monitoring Network
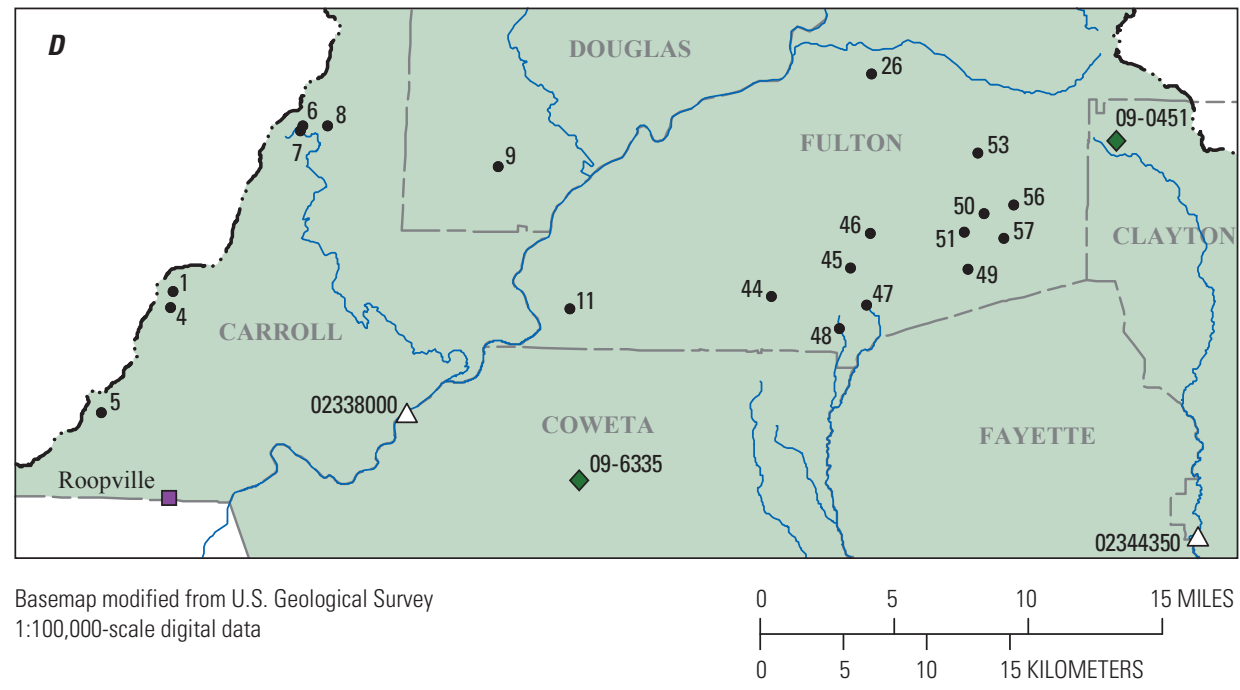
Table 1. Sources of basin characteristic and population data.

[m, meter; DEM, digital elevation model; NA, not applicable]

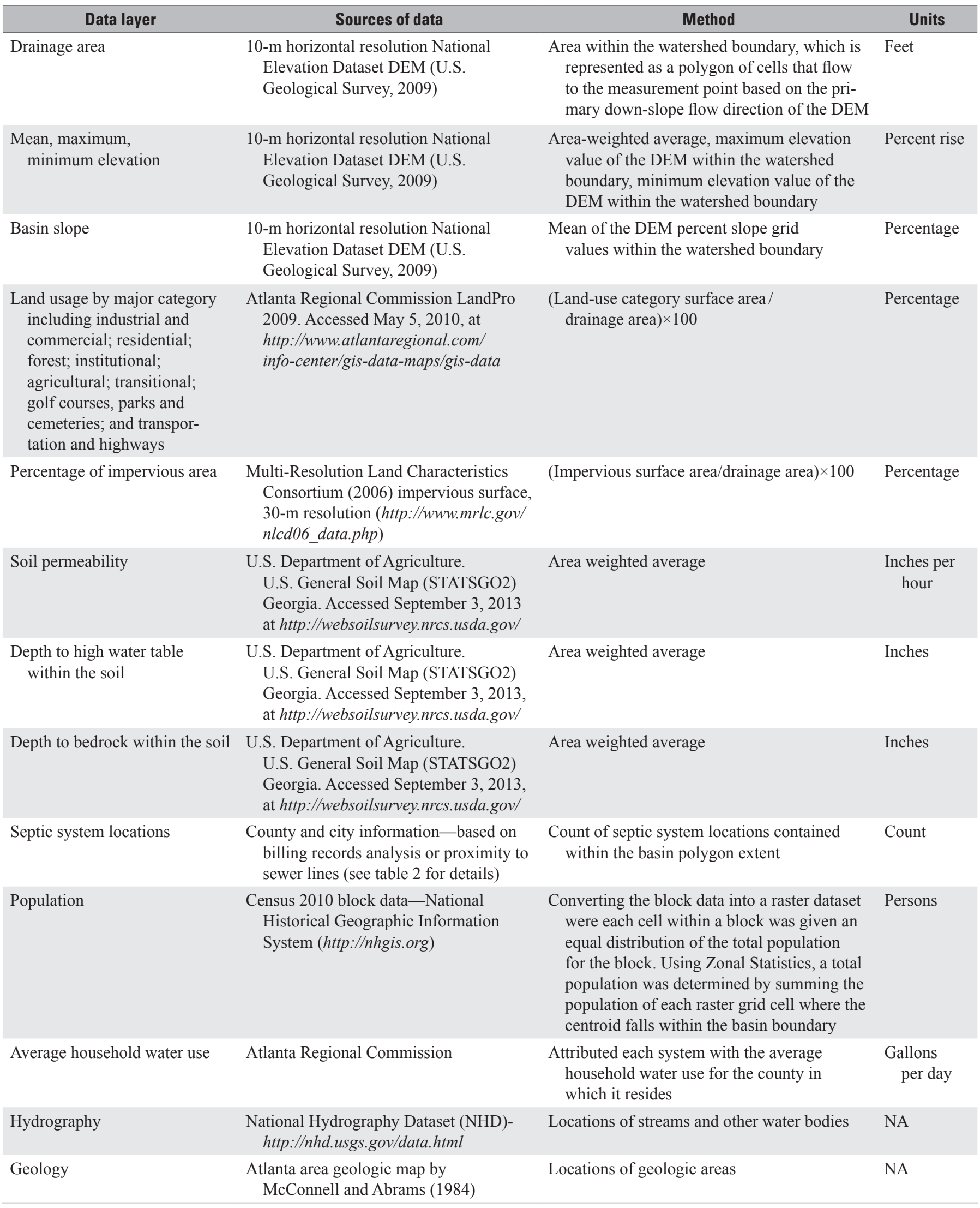


Table 2. Sources of information and procedures used to estimate septic system locations.

[NA, not applicable]

\begin{tabular}{|c|c|c|}
\hline County & City & Type of information \\
\hline Carroll & NA & $\begin{array}{l}\text { Provided a list of address for water customers and a list of sewer customers. Determined the difference between } \\
\text { the two and georeferenced the addresses. Using a parcel dataset and the number of bathrooms assigned to } \\
\text { each parcel we generated an improved parcel dataset. Joined the georeferenced water only customer locations } \\
\text { to the nearest improved parcel and attributed those as septic parcels. }\end{array}$ \\
\hline Clayton & NA & $\begin{array}{l}\text { Provided a table of improved parcels and addresses of sewered customers. The parcelid from the table was } \\
\text { linked to the spatial dataset of parcels in Paulding County. The improved parcels that were remaining we } \\
\text { attributed as septic. }\end{array}$ \\
\hline Cobb & NA & Provided water only customers. \\
\hline Cobb & Austell & Provided a table of septic tank locations. Georeferenced the addresses and created a point feature dataset. \\
\hline Cobb & Marietta & Provided a spatial dataset of parcels that were not on sewer. Those were considered septic parcels. \\
\hline Cowetta & NA & $\begin{array}{l}\text { Provided address of sewered addresses, improved parcel dataset. Took the remaining improved parcels and } \\
\text { attributed as septic. }\end{array}$ \\
\hline Fayette & NA & $\begin{array}{l}\text { Provided a table of improved parcels and addresses of sewered customers. The parcelid from the table was } \\
\text { linked to the spatial dataset of parcels in Paulding County. The improved parcels that were remaining we } \\
\text { attributed as septic. }\end{array}$ \\
\hline Fayette & Newnan & Provided sewer lines and water only billing addresses. \\
\hline Forsyth & NA & Provided a feature dataset of water and sewer customers. \\
\hline Fulton & NA & Provided feature dataset of septic system locations. \\
\hline Hall & Gainesville & Provided metered parcels that were not sewered. Took the cell centroid of the parcel- attributed as septic. \\
\hline Gwinnett & NA & Provided feature dataset of septic system locations. \\
\hline
\end{tabular}


To quantify base flow, 133 small watersheds (less than $5-\mathrm{mi}^{2}$ drainage area) with similar land use, soil, geologic, and topographic conditions were selected for evaluation. To ensure a large contrast in septic system density, study basins were subdivided into three categories:

- High density septic (HDS) - the upper 33 percent of sites in terms of septic system density, ranging from 179 to 903 septic systems $/ \mathrm{mi}^{2}$ (46 sites);

- Low density septic (LDS) - the lower 33 percent of sites in terms of septic system density, ranging from 0 to 37 septic systems $/ \mathrm{mi}^{2}$ (45 sites); and

- Middle range - the middle 33 percent of sites in terms of septic system density, ranging from 38 to 178 septic systems $/ \mathrm{mi}^{2}$ (43 sites).

This grouping is in contrast to the classification of Landers and Ankcorn (2008), who designated an arbitrary cutoff of less than 100 systems $/ \mathrm{mi}^{2}$ for LDS basins and greater than 200 systems $/ \mathrm{mi}^{2}$ for HDS basins.

In each basin, groundwater contribution to streamflow (base flow) was quantified using synoptic measurements from September 10 to 13, 2012, during drought conditions. Discharge was measured using volumetric methods at culvert outfalls or velocity-area methods in the channel as described in Rantz (1982). With each discharge measurement, field measurements of specific conductance, water temperature, dissolved oxygen, and $\mathrm{pH}$ of stream water were collected using a calibrated multiparameter water-quality meter (Wilde and others, 1998). Because many of the streamflow measurements were made during extremely low-flow conditions, the margin of error is increased, with many measurements having errors greater than 10 percent. Measurement accuracy is listed in appendix 1.

Streamflow and field water-quality properties were compared between HDS and LDS basins. Because of the large size of the study area and associated variations in geologic setting, topography, land use, impervious area, elevation and slope, soil properties, and population, data collected in September 2012 were evaluated using a number of groupings. These groupings were developed in an attempt to reduce or eliminate other basin characteristics that might affect base flow (fig. 2). The four groupings are (1) all sites, (2) septic density range within a 45-meter stream-buffer area, (3) four geographic subareas, and (4) three geologic areas.
Streamflow data from HDS and LDS basins were compared using a variety of statistical approaches:

- Scatterplot and boxplot to summarize streamflow data and basin characteristics,

- Linear regression to determine the relation of streamflow to septic system density and basin characteristics, and

- Wilcoxon rank-sum testing to determine whether the median differences in streamflow and field waterquality properties between HDS and LDS watersheds are statistically significant.

Scatterplots and boxplots provided a visual means to assess the distribution of data among the various groupings. The multiple linear regression analysis was completed by culling zero streamflow values from the 133 sites measured in September 2012 (including HDS, LDS, and "middle range" sites), resulting in a dataset of values from 94 sites.

The Wilcoxon testing procedure involved comparing the ranks of two data populations and assessing whether the median of each group was statistically the same or different. The null hypothesis is that the median for HDS watersheds is higher than for LDS watersheds, and the alternative hypothesis is that the median for HDS watersheds is the same as the median for LDS watersheds. A computed p-value equal to or less than the significance level of 0.05 , was used as a basis for acceptance of the null hypothesis.

To evaluate how base flow varies on a seasonal basis, daily data from two USGS streamgages were evaluated using the computer program HYSEP (Sloto and Crouse, 1996), which separates streamflow into base-flow and runoff components. HYSEP uses three methods to separate base flow: fixed interval, sliding interval, and local minimum. Each method uses a different algorithm to separate base flow systematically from runoff by connecting low points on the streamflow hydrograph. The duration of surface runoff is calculated based on the relation

$$
\mathrm{N}=\mathrm{A}^{0.2},
$$

where

$$
\begin{gathered}
\mathrm{N} \text { is the number of days for runoff to cease, and } \\
\text { A is the basin drainage area (Linsley and } \\
\text { others, 1982). }
\end{gathered}
$$

The local-minimum method was applied whereby streamflow is evaluated to determine whether each daily measurement is the lowest streamflow value for one-half the interval minus 1 day $(0.5(2 \mathrm{~N} \times-1)$ days), with no overlap of intervals allowed (Sloto and Crouse, 1996). This procedure tends to reduce overestimation of base flow (Priest, 2004). 


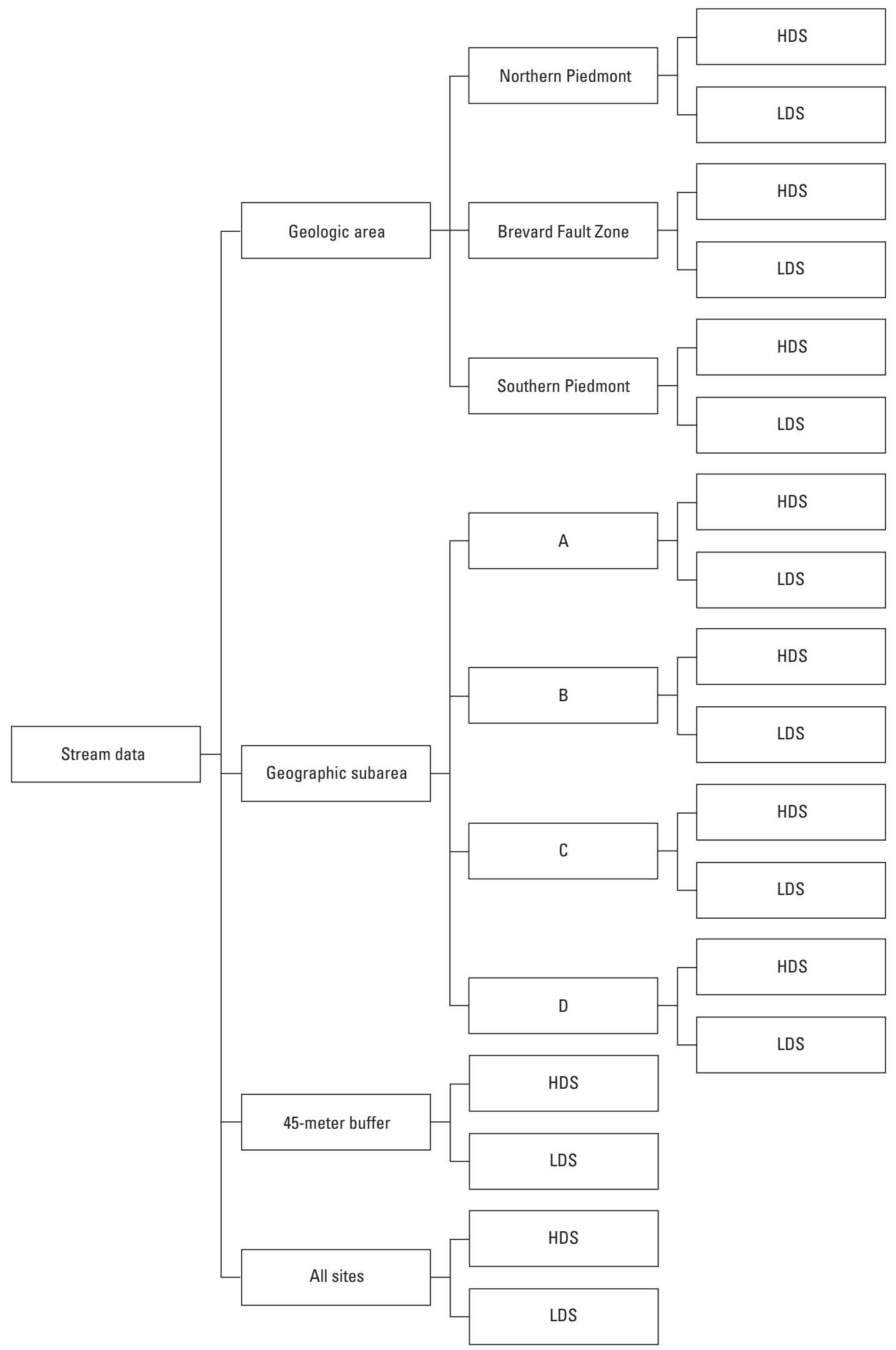

Figure 2. Flowchart showing procedure for evaluating basins with high and low density of septic systems. [HDS, high density septic; LDS, low density septic] 


\section{Description of Study Area}

The ACF River Basin includes parts of Alabama, Florida, and Georgia (fig. 1). The study area covers $2,539 \mathrm{mi}^{2}$ in the upper part of the ACF River Basin in Georgia. All or parts of 12 counties that include and surround Metropolitan Atlanta in the 28-county Metropolitan Atlanta area are within the study area (U.S. Department of Housing and Urban Development and U.S. Census Bureau, 2005).

The study area is part of the 15-county Metropolitan North Georgia Water Planning District established by the Georgia General Assembly in 2001 to facilitate "development of comprehensive regional water resources plans that protect water quality and water supply in and downstream of the region, protect recreational values of the waters in and downstream of the region and minimize potential adverse impacts of development on waters in and downstream of the region" (Metropolitan North Georgia Water Planning District, 2013).

\section{Physiography}

The study area lies in the Piedmont physiographic province, an area characterized by rolling hills and isolated mountains (fig. 3). Elevation ranges from as high as 2,586 ft to the northeast in Hall County, Ga., upstream of Lake Sidney Lanier, to as low as $563 \mathrm{ft}$ to the southwest in Coweta County, Ga. (fig. 4). Slope is less than 12 percent over most of the study area and greatest in tributary stream valleys adjacent to the Chattahoochee River, where values generally range between 24 and 36 percent (fig. 5).

Clark and Zisa (1976) designated four physiographic districts within the study area: Central Uplands, Gainesville Ridges, Winder Slope, and Greenville Slope (fig. 3). The northeast trending geologic structure of the Central Uplands and Gainesville Ridges Districts control the course of the Chattahoochee River and its tributaries. In the Gainesville Ridges District, faults and fractures produced a rectangular drainage pattern in the Chattahoochee River Basin. Within the Central Uplands and Gainesville Ridges Districts, elevations range from about $1,500 \mathrm{ft}$ in the northeast and to about $1,000 \mathrm{ft}$ in the southwest.

The Winder and Greenville Slope Districts are characterized by gently rolling topography. The Greenville Slope District underlies the headwaters of the Flint River, with elevations ranging from 800 to $1,000 \mathrm{ft}$ along the southern extent of the study area. The district is characterized by dendritic drainage patterns in which broad, shallow valleys are separated by broad, rounded divides.

\section{Geology}

The Piedmont physiographic province is underlain by structurally deformed metamorphic and igneous rocks. Major, long-inactive fault zones divide the Piedmont into several belts that generally have a northeastern strike. One of the most prevalent of these features, the Brevard fault zone, is a primary control on the path of the Chattahoochee River (fig. 6).

McConnell and Abrams (1984) described the geology of the greater Atlanta area, delineating several major geologic formations and groups that are subdivided into rocks of the northern and southern Piedmont, separated by the Brevard fault zone. The northern and southern Piedmont consist of structurally deformed, metamorphosed volcanic and sedimentary rocks and are intruded by granite plutons in parts of the area (McConnell and Abrams, 1984). Major lithologies include granite gneiss, quartzite, schist, and amphibolite.

The Brevard fault is a zone of ductile shearing that is traceable from Alabama through Georgia and South Carolina into North Carolina. Rocks in the Brevard fault zone include mylonite, button schist, and gneiss that are sheared and fractured, forming parallel ridges that control much of the course of the Chattahoochee River.

\section{Climate}

The study area has a humid subtropical climate. Climatic conditions in the study area are reported as the climatic normals during the 1971-2000 period at three National Weather Service stations within the study area: Gainesville, in Hall County (09-3621, fig. 1A); Atlanta Airport, in Clayton County (09-0451, fig. 1D); and Newnan, in Coweta County (096335, fig. 1D). Mean daily temperatures peak during July, ranging from about 87 degrees Fahrenheit $\left({ }^{\circ} \mathrm{F}\right)$ at Gainesville, to $89^{\circ} \mathrm{F}$ at Atlanta Airport and Newnan. Minimum annual temperatures occur in January, ranging from $31.4^{\circ} \mathrm{F}$ at Gainesville, to $33.5^{\circ} \mathrm{F}$ at Atlanta Airport.

Average annual rainfall ranges from 50.22 inches at Atlanta Airport, to 54.72 inches at Gainesville. Seasonal rainfall is generally highest in January at Gainesville (5.91 inches), and in March at Atlanta Airport (5.15 inches) and Newnan (5.54 inches). Minimum rainfall occurs in June at Gainesville (3.87 inches) and in October at Atlanta Airport (3.34 inches) and Newnan (3.07 inches).

Average annual potential evapotranspiration (PET) was computed at Georgia Environmental Monitoring Network sites at Gainesville, Atlanta Airport, and Roopville (fig. $1 A, C, D$ ) using the Priestley-Taylor method (Stewart and Rouse, 1976). PET is a measure of the ability of the atmosphere to remove water through the processes of evaporation and transpiration, whereas actual evapotranspiration is the actual quantity of water removed by evaporation and transpiration. 


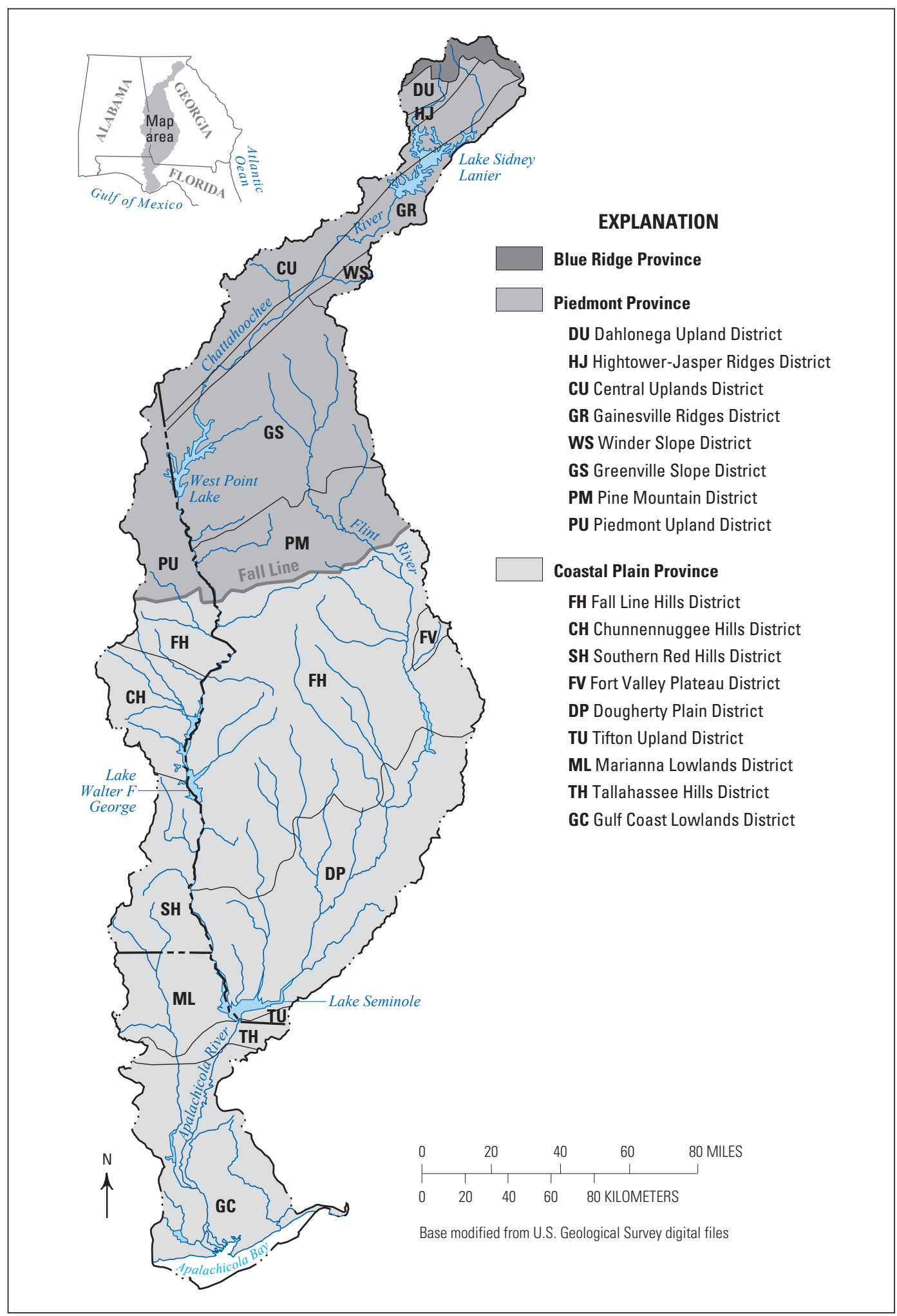

Figure 3. Physiographic provinces and districts of the Apalachicola-Chattahoochee-Flint River Basin (modified from Copeland, 1968; Clark and Zisa, 1976; Lietman and others, 1983). 


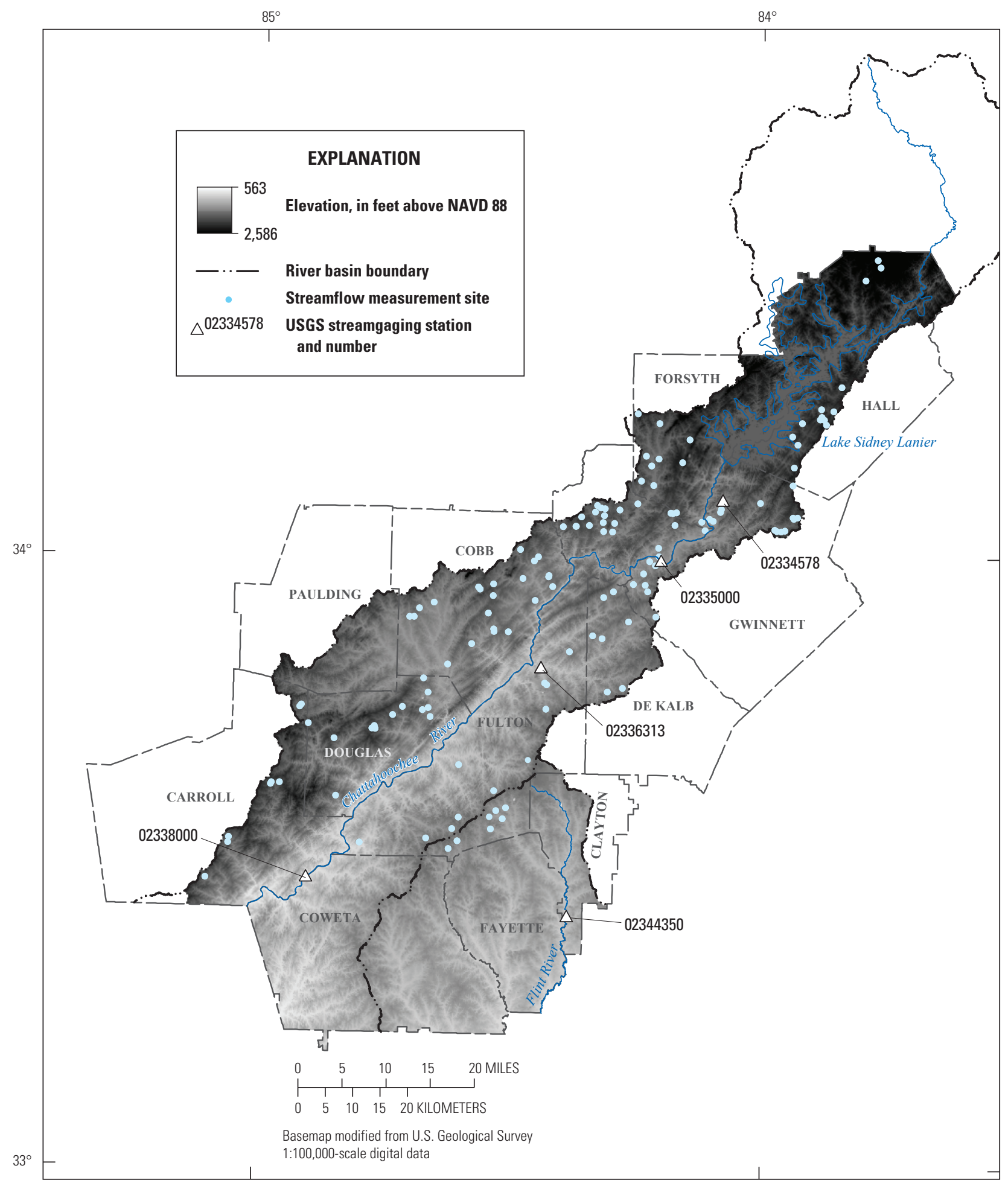

Figure 4. Elevation in the study area (data from U.S. Geological Survey, 2009). 


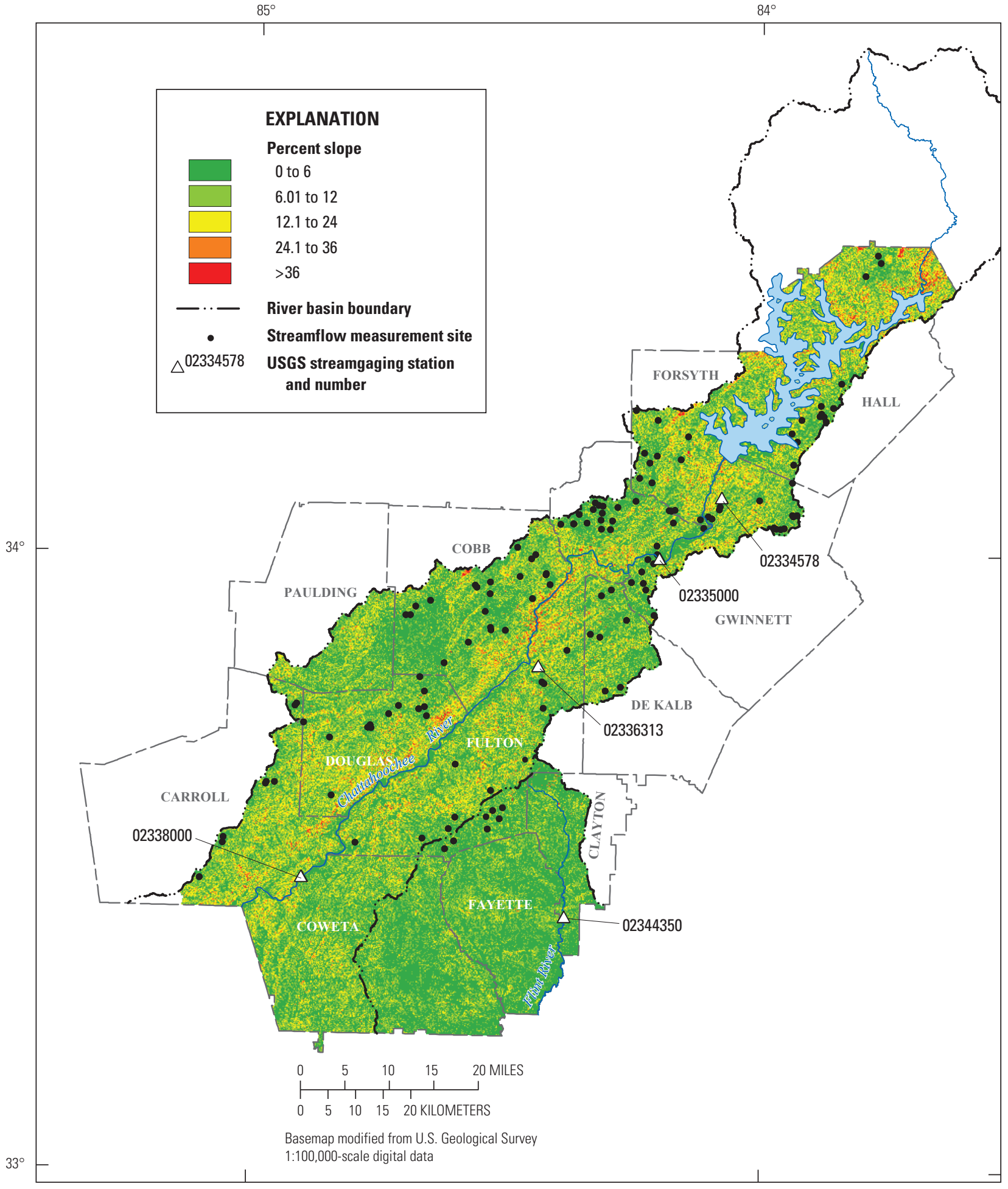

Figure 5. Percent slope in the study area (data from U.S. Geological Survey, 2009). 


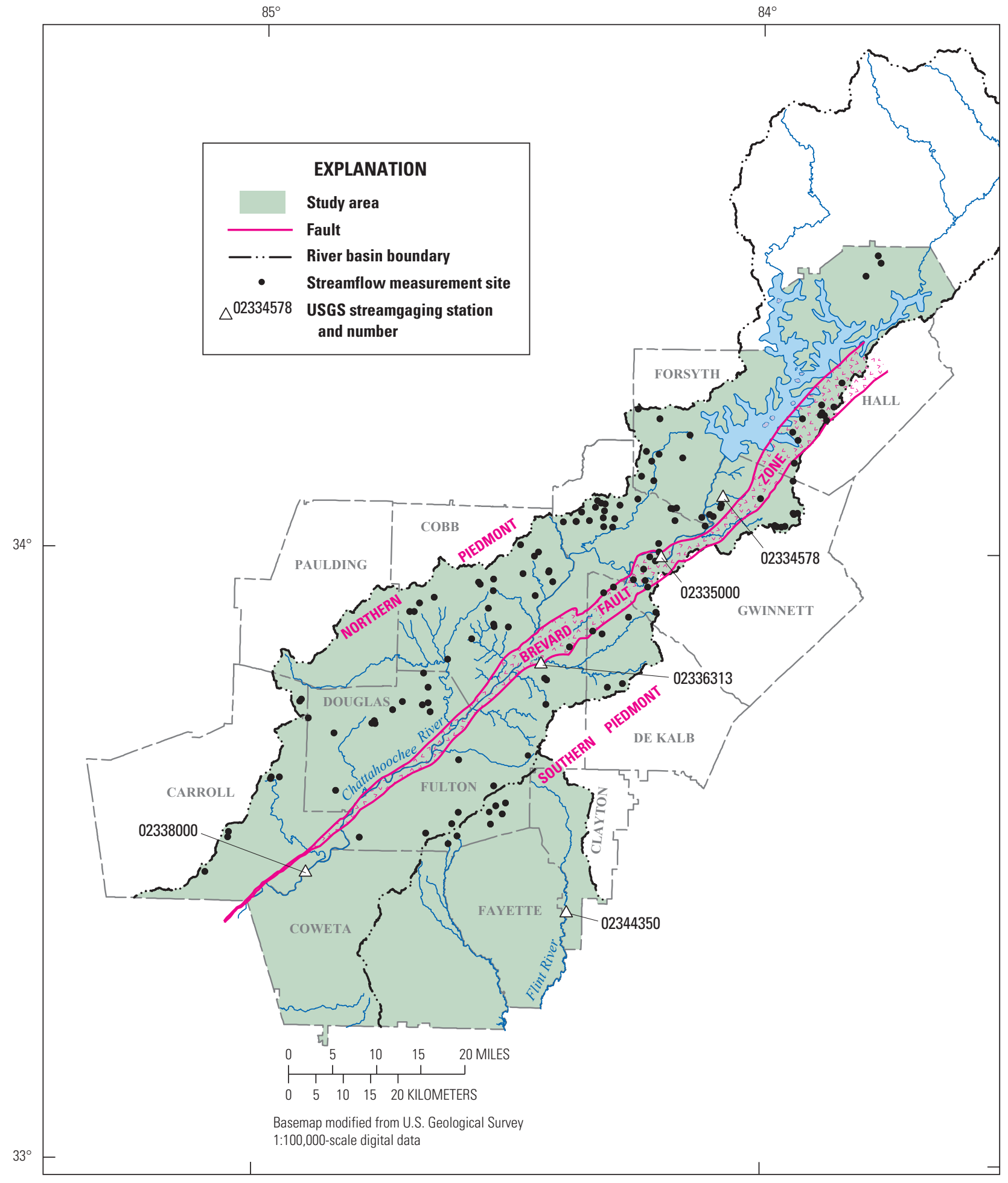

Figure 6. Geologic areas of northern Georgia (modified from McConnell and Abrams, 1984). 
During 1971-2000, average annual PET was 18.98 inches at Gainesville, 19.73 inches at Atlanta Airport, and 19.07 inches at Roopville (Georgia Automated Environmental Monitoring Network, 2013). PET is greatest during the summer months, ranging from 5.97 inches at Roopville in June to 6.38 inches at Atlanta Airport in July. Minimum PET occurs during the winter months (December) ranging from 0.4 inch at Gainesville to 0.46 inch at Atlanta Airport.

A larger proportion of precipitation is available to recharge groundwater and provide base flow to streams during periods of maximum precipitation and minimum evapotranspiration. Conversely, minimum recharge and base flow to streams occurs during periods of maximum evapotranspiration and minimum precipitation. During extreme drought conditions, little water is available in the soil for loss to evapotranspiration, and PET is greater than the actual amount of evapotranspiration.

\section{Surface-Water Hydrology}

The study area lies within the upper part of the ACF River Basin in Georgia, and includes Lake Sidney Lanier in Hall County and headwaters of the Flint River in Clayton, Fayette, and Coweta Counties. The flow of the Chattahoochee River is regulated primarily by Buford Dam, which forms Lake Sidney Lanier, a 1,040- $\mathrm{mi}^{2}$ impoundment operated by the U.S. Army Corps of Engineers. The Chattahoochee and Flint Rivers provide drinking water and serve as the primary repository for treated wastewater effluent in the study area. The two rivers merge downstream of Lake Seminole to form the Apalachicola River, which discharges into Apalachicola Bay in the Gulf of Mexico (fig. 3).

The flow and drainage area of the Chattahoochee River both increase downstream through the study area. Monthly mean flow at the Chattahoochee River at the Norcross gage (02335000, fig. $1 B$ ) during water years ${ }^{1}$ 2011-12 ranged from 860 cubic feet per second $\left(\mathrm{ft}^{3} / \mathrm{s}\right)$ on February 2012, to $3,495 \mathrm{ft}^{3} / \mathrm{s}$ on March 2011. Further downstream at the Whitesburg gage (02338000, fig. $1 D)$, monthly mean flow was higher, ranging from $1,252 \mathrm{ft}^{3} / \mathrm{s}$ in September 2012, to $6,601 \mathrm{ft}^{3} / \mathrm{s}$ in March 2011. In the Flint River Basin, flow at gage 02344350 near Lovejoy (fig. $1 D$ ) during water years 2011-12 ranged from $10.6 \mathrm{ft}^{3} / \mathrm{s}$ in September 2012 to $360 \mathrm{ft}^{3} / \mathrm{s}$ in March 2011.

\footnotetext{
${ }^{1} \mathrm{~A}$ water year is defined as the 12-month period October 1 , for any given year through September 30, of the following year. The water year is designated by the calendar year in which it ends and which includes 9 of the 12 months. Thus, the year ending September 30, 2012 is called the "2012" water year.
}

This study focuses on small basins within the study area that cover less than $5 \mathrm{mi}^{2}$ because lower streamflow should make it easier to quantify base-flow variations between the streams that result from the presence of septic systems than in larger basins with higher streamflow. The flow characteristics of such small watersheds are illustrated by the hydrographs of two streamgages: 02334578, Level Creek at Suwannee Dam Creek near Suwannee, Ga., and 02336313 Woodall Creek at Defoors Ferry Road, at Atlanta, Ga. (fig. 7). Streamflow at the two gages shows a flashy response to rainfall events, both peaking during storms and receding to base-flow conditions quickly.

\section{Groundwater Hydrology}

Groundwater in the Piedmont primarily resides in regolith and fractures in the bedrock (Cressler and others, 1983). Shallow groundwater flow and most groundwater storage occur in the regolith, which consists of soil, alluvium, and weathered bedrock or saprolite. Groundwater flow in the regolith generally occurs within surface-water basins, whereby water enters (recharges) in upland areas and discharges to streams. Water moving into bedrock is controlled, in part, by the depth and orientation of structural features, such as joints and fractures, and may not be restricted to surface-water basin boundaries. The geology of the study area is considerably more complex at a local scale than that shown on the regional map (fig. 6); therefore, geologic variations that might affect groundwater flow and base-flow yield may not be captured by the analysis presented in this report. 
Site 02334578 (Level Creek)

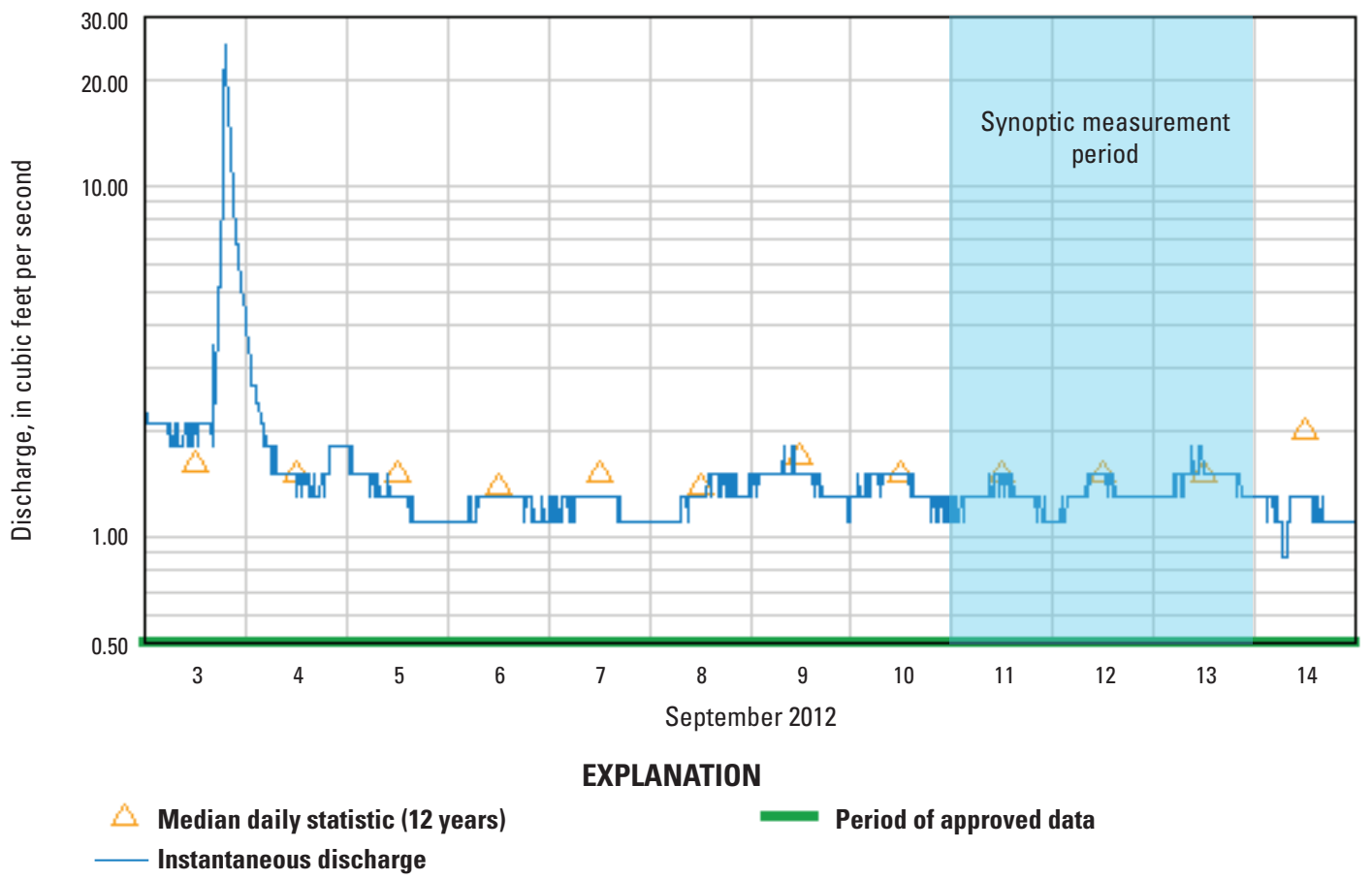

Site 02336313 (Woodall Creek)

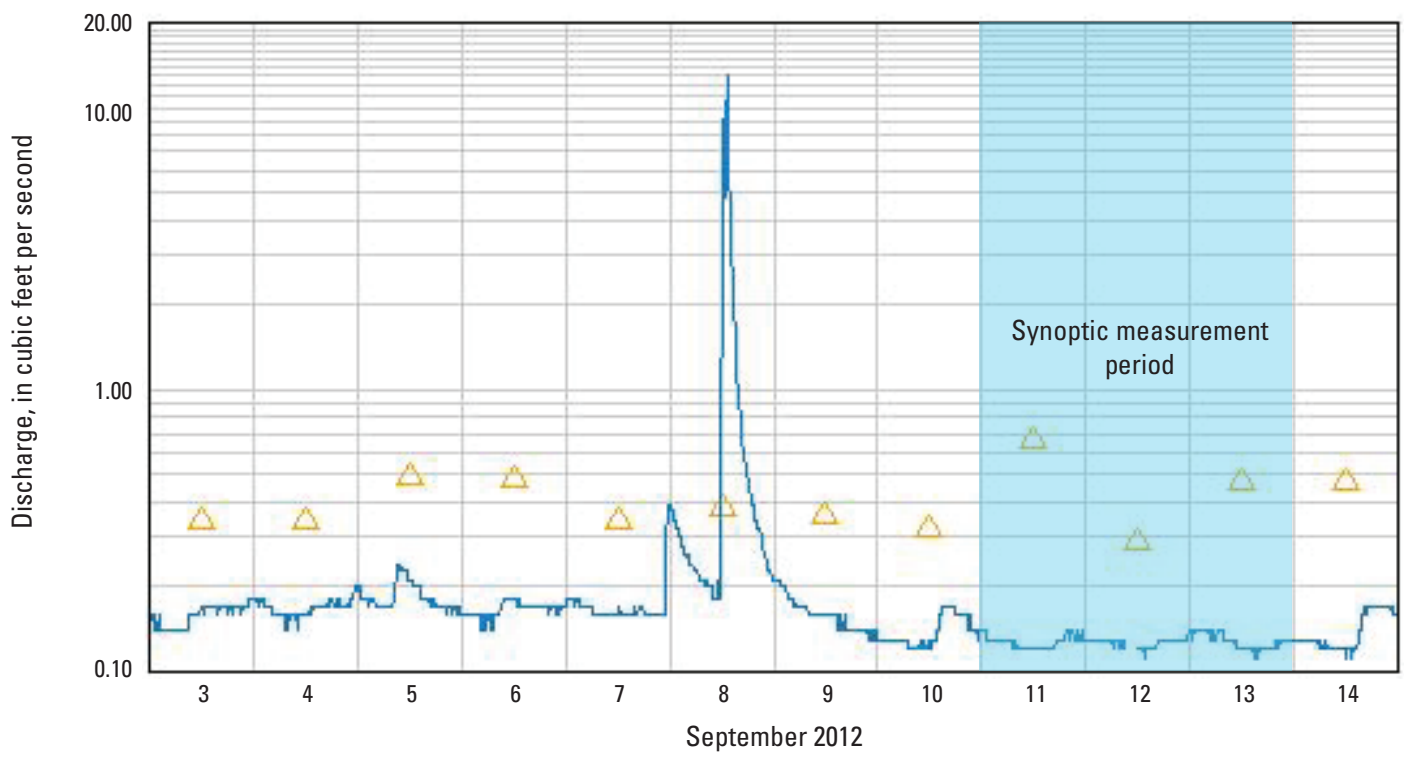

EXPLANATION

Median daily statistic $(5$ years $)$

— Instantaneous discharge

Figure 7. Stream discharge at USGS site 02334578 Level Creek at Suwannee Dam Creek near Suwannee, GA, and USGS site 02336313 Woodall Creek at Defoors Ferry Road, at Atlanta, GA, September 3-14, 2012. 


\section{Land Use}

The largest land use category in the study area is residential ( 37 percent), followed by forest ( 28 percent), and agricultural (12 percent). Other land use classifications include transportation and highways; industrial and commercial; water bodies, golf courses, parks, and cemeteries; and transitional (fig. 8). Impervious area was based on the 2006, 30-meter National Land Cover Database (NLCD) delineation (http://www.mrlc.gov/nlcd06_data.php, fig. 9). Impervious areas block infiltration of precipitation to the groundwater system and affect streamflow. Streams in basins having a large percentage of impervious area tend to be flashy, with higher flood peaks and lower base flow relative to other basins. In the study area, impervious area is greatest in the vicinity of the city of Atlanta in Fulton, Dekalb, Cobb, and Gwinnett Counties, and south of Atlanta in Clayton County.

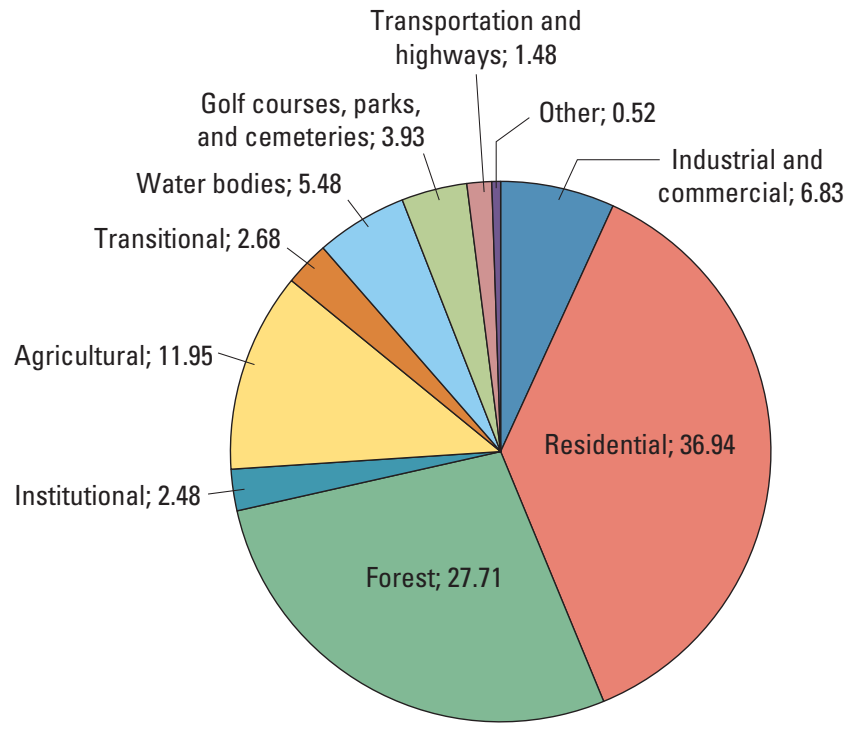

Figure 8. Land use in the study area, 2009 (data from Atlanta Regional Commission, 2009). 


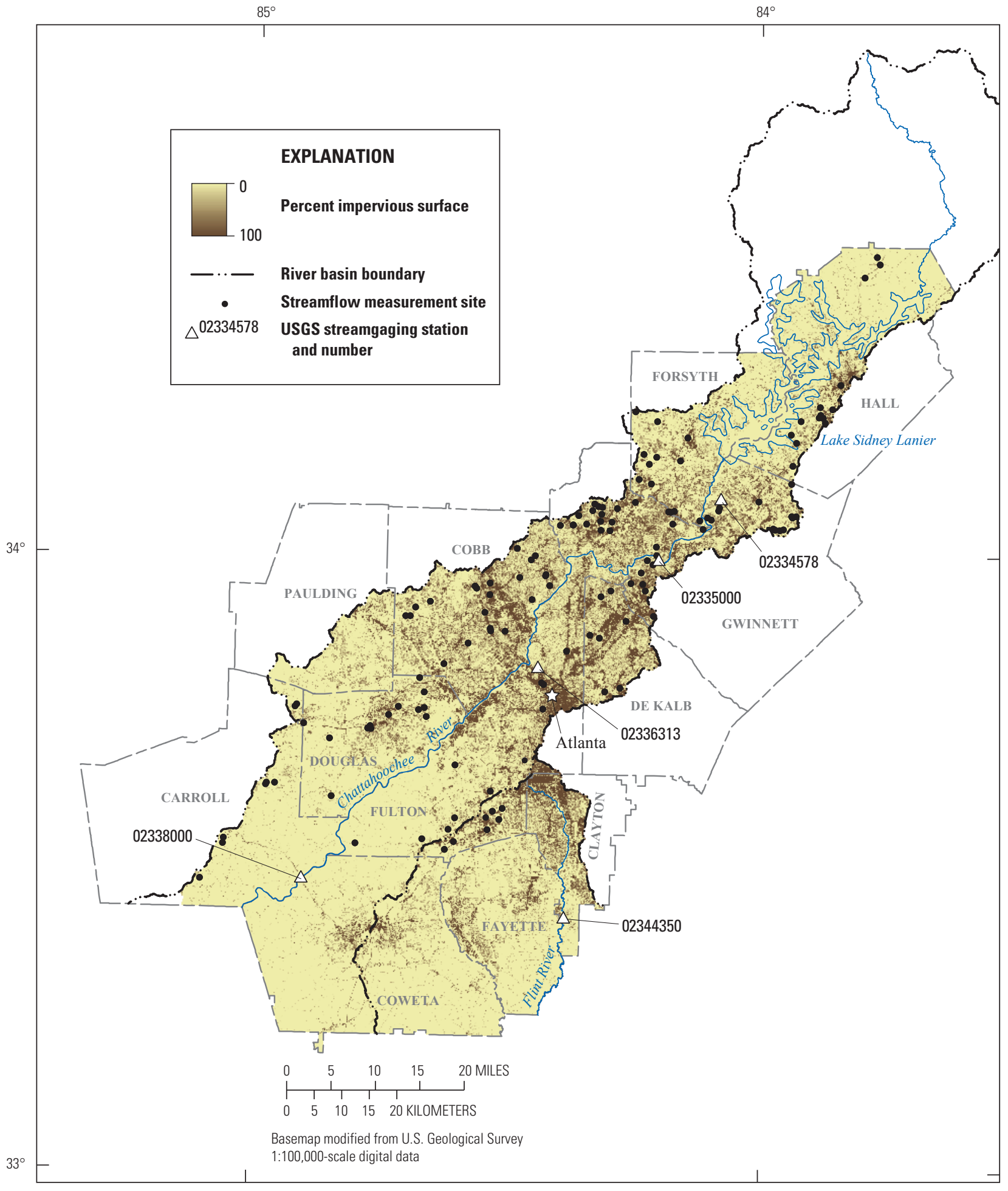

Figure 9. Percentage of impervious area in the study area, 2006 (see table 1 for data source). 


\section{Water Use}

During 2010, water from the Chattahoochee and Flint Rivers supplied 456 million gallons per day (Mgal/d) in the 12-county study area, with $277 \mathrm{Mgal} / \mathrm{d}$ or 61 percent returned to streams as treated discharge from sewer systems (Steven J. Lawrence, U.S. Geological Survey, written commun., December 12, 2013). Of the remaining 39 percent, some of the water is discharged to streams outside of the basin or is (1) lost to evapotranspiration; (2) incorporated into a product or a crop; (3) consumed by humans or animals; or (4) is discharged into shallow groundwater from septic systems, leaky pipes, or land application of effluent discharge.

Streamwater withdrawal and discharge vary across the ACF River Basin (fig. 10). In general, water is withdrawn from the upper part of the basin and is moved downstream toward more populated areas in the middle part of the basin where it is subsequently discharged. In the upper Chattahoochee Basin, water withdrawal exceeds discharge, with respective amounts of 358 and $92 \mathrm{Mgal} / \mathrm{d}$. Further downstream, in the middle Chattahoochee Basin, water discharge (178 Mgal $/ \mathrm{d})$ exceeds withdrawal $(78 \mathrm{Mgal} / \mathrm{d})$. In the upper Flint Basin, water withdrawal (21 Mgal/d) exceeds discharge (6.8 Mgal/d). Here, several water utilities use land-application systems to discharge sewage effluent, which may account for the smaller discharge in this area.

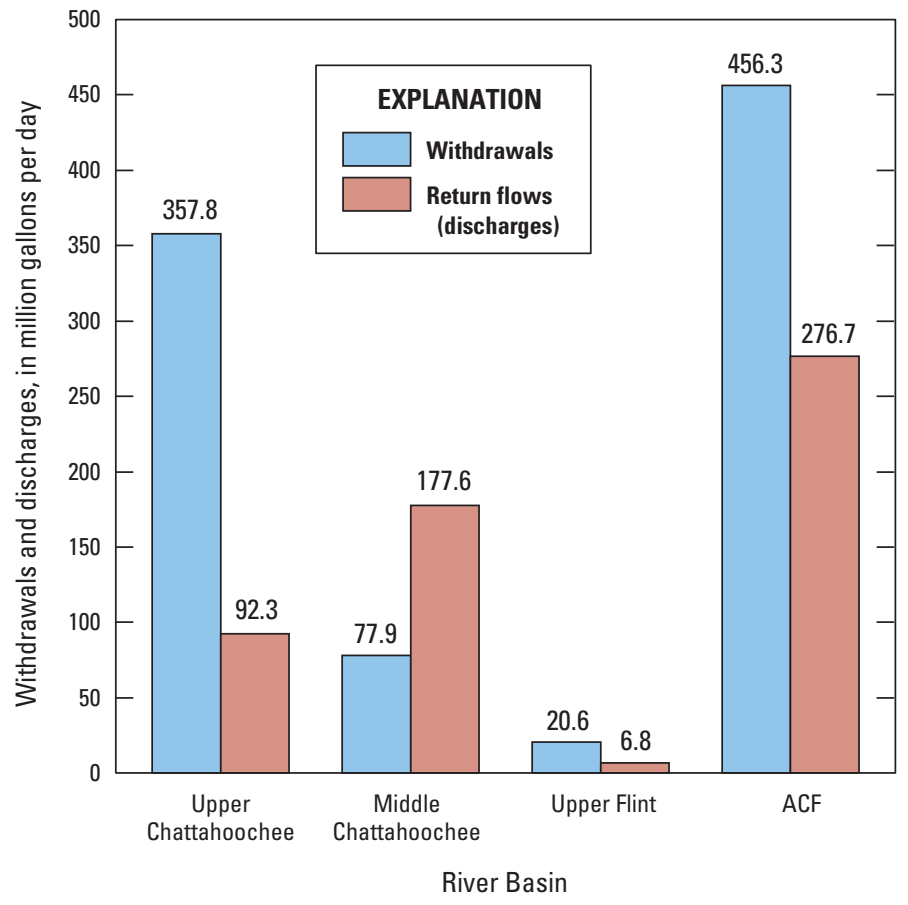

Figure 10. Average annual surface-water withdrawals and return flows within the upper and middle Chattahoochee, upper Flint, and Apalachicola-Chattahoochee-Flint (ACF) River Basins in the study area, 2010. 


\section{Influence of Septic Systems on Stream Base Flow}

Septic systems - also referred to as septic tanks, individual sewage management systems, on-site sewage management systems, or on-site wastewater treatment systems - generally consist of a watertight septic tank and an effluent-disposal absorption field. The septic tank and soil surrounding the absorption field break down waste though biological, chemical, and physical processes. Most solid wastes are trapped in the septic tank, with liquid wastes flowing into an absorption field consisting of perforated drainage pipes that distribute the septic tank effluent in shallow trenches filled with a porous medium (U.S. Environmental Protection Agency, 2002; Georgia Division of Public Health, 2007). Over time, solids accumulate in the septic tank, and if not properly cleaned and maintained, may clog the absorption field. Other causes of system failure include unsuitable soil and location, age, excessive water use, poor maintenance, and surface runoff (Metropolitan North Georgia Water Planning District, 2006).

Water from the absorption field infiltrates through the unsaturated zone and into the water table (fig. 11). According to Landers and Ankcorn (2008), a typical septic installation in Metropolitan Atlanta consists of a 1- to 4-ft-deep absorptionfield trench, with a minimum distance of $2 \mathrm{ft}$ above the maximum groundwater table or any impervious layer. The rate of infiltration into groundwater depends on the permeability of the soil beneath the absorption field, the depth of the water table, and the amount of wastewater entering the septic system. In addition, clogging in the septic tank and absorption field may diminish infiltration. In some instances, vegetation located over the absorption field may transpire water that otherwise would have infiltrated into groundwater.

Beneath the absorption field, the infiltrating water raises the local water table, increasing the hydraulic gradient from the absorption field to nearby streams. Once water enters the groundwater system, some is lost to evapotranspiration, with the remaining portion discharging to streams as base flow or moving into deeper parts of the groundwater system. The amount of evapotranspiration loss is mitigated by design manuals, which specify that absorption fields be located away from large vegetation with deep root structure (Georgia Division of Public Health, 2007). As groundwater flows away from the absorption field, the amount of evapotranspiration is controlled by the depth of the water table and the presence of high-water-demand plants with deep root structure.

Domestic water use can be classified into two principal categories: household use, such as for drinking water and food preparation, baths and showers, washing machines, toilets, and dishwashers; and outdoor use, principally for lawn or garden irrigation. Most household water passes through septic systems, whereas outdoor water is applied directly to the landscape. Because household use varies little during the

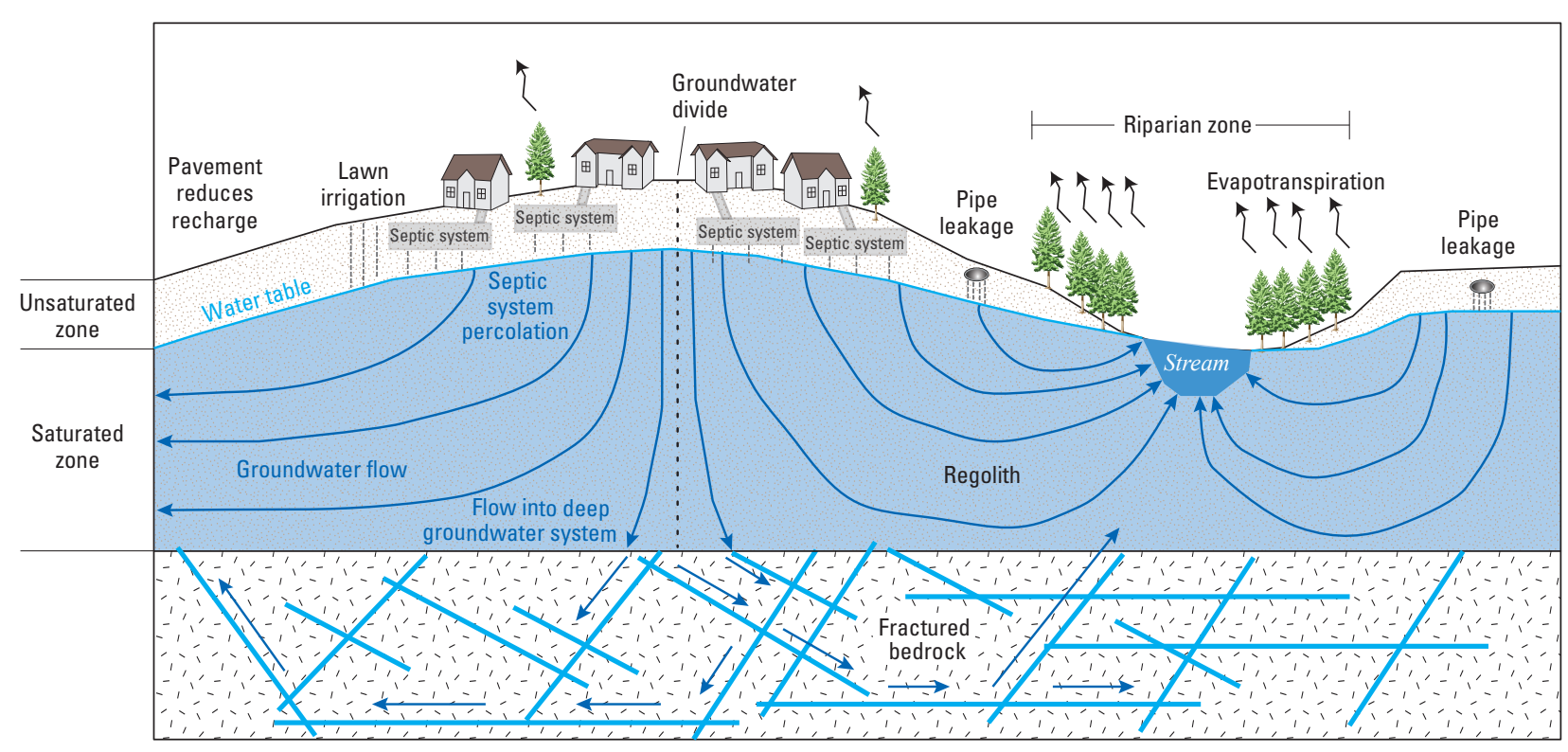

NOT TO SCALE

Figure 11. Conceptual diagram of groundwater flow in the vicinity of septic systems, groundwater divides, and streams during dry hydrologic conditions. Septic system includes absorption field. Pipe leakage includes water mains, sanitary sewers, and storm drains. 
year, properly designed septic systems, installed at sufficient depths and away from vegetation with deep root systems, are believed to provide a constant source of water to the shallow groundwater system. Outdoor use can be substantially higher during the summer irrigation period. A portion of this irrigation water may recharge the shallow groundwater system and discharge into streams.

The amount of groundwater reaching streams is dependent on how much is intercepted by plants or infiltrates to deeper parts of the groundwater system. Evapotranspiration varies seasonally and is greatest during the growing season. Thus, it is likely that greater amounts of groundwater discharge into streams during the nongrowing season.

In addition to septic systems, leaking water mains and sanitary sewers, storm water drains, and runoff diversion and storage structures can contribute to enhanced groundwater recharge. A groundwater modeling and end-member mixing study of water chemistry by Yang and others (1999) found that water-main and sewer leakage contributed over 70 percent of the recharge in an urban setting in Nottingham, England.

\section{Distribution of Septic Systems}

Data from local utilities were compiled to develop a GIS database of septic system locations. In the study area, more than 241,733 septic systems were identified and the density per square mile within each drainage basin was determined (fig. 12). The highest density of septic systems is in the southern part of Forsyth County where the density exceeds 350 systems $/ \mathrm{mi}^{2}$. Other areas having HDS include southeastern Paulding, central Douglas, and south-central Hall Counties, where density exceeds 250 systems $/ \mathrm{mi}^{2}$.

The Metropolitan North Georgia Water Planning District (2006) completed a survey of septic systems that indicated

- 26 percent of housing units in the district are served by septic systems;

- 40 percent of septic systems are more than 20 years old;

- the minimum permitted lot size for septic systems ranges, by county, from 0.46 to 1.6 acres; and that
- septic systems generally are located outside the extent of sewer lines; however, this is not always the case.

These findings indicate a large number of homes in the area are served by septic systems, with a potential large effect on base flow. Because a relatively large number of systems are more than 20 years old, there is increased potential for clogging and system failure, which might change the amount of water reaching the groundwater system.

\section{Site Characteristics of Study Area Basins}

Land use characteristics were categorized according to the HDS/LDS classification and are listed in appendix 2 and summarized in figure 13. The largest percentage of land use for both HDS and LDS basins was medium-density residential, which accounted for 45 and 32 percent, respectively of the total land use. The percentage distribution for forest, transitional, and other land-use classifications was similar in HDS and LDS basins. LDS basins had large percentages of land use for commercial and industrial, transportation, multifamily residential, and institutional classes, whereas HDS basins had larger percentages of agricultural and lowand medium-density residential classes. This breakdown is generally consistent with the following expected distribution of septic systems:

- More septic systems would be expected in residential areas, as indicated by greater low- and medium-density residential classifications, and in rural areas, as indicated by greater agricultural classification.

- Fewer septic systems would be expected in more urban settings that are typically covered by sewer lines, as indicated by greater commercial and industrial, multifamily residential, and institutional classifications.

In addition to land use classification, drainage area, impervious area, and topographic and soil characteristics were compiled and summarized according to the HDS/LDS classification (fig. 14). HDS basins had a slightly higher median water-table depth, bedrock depth, and average elevation than LDS basins. LDS basins had a higher median population density and impervious area than HDS basins. 


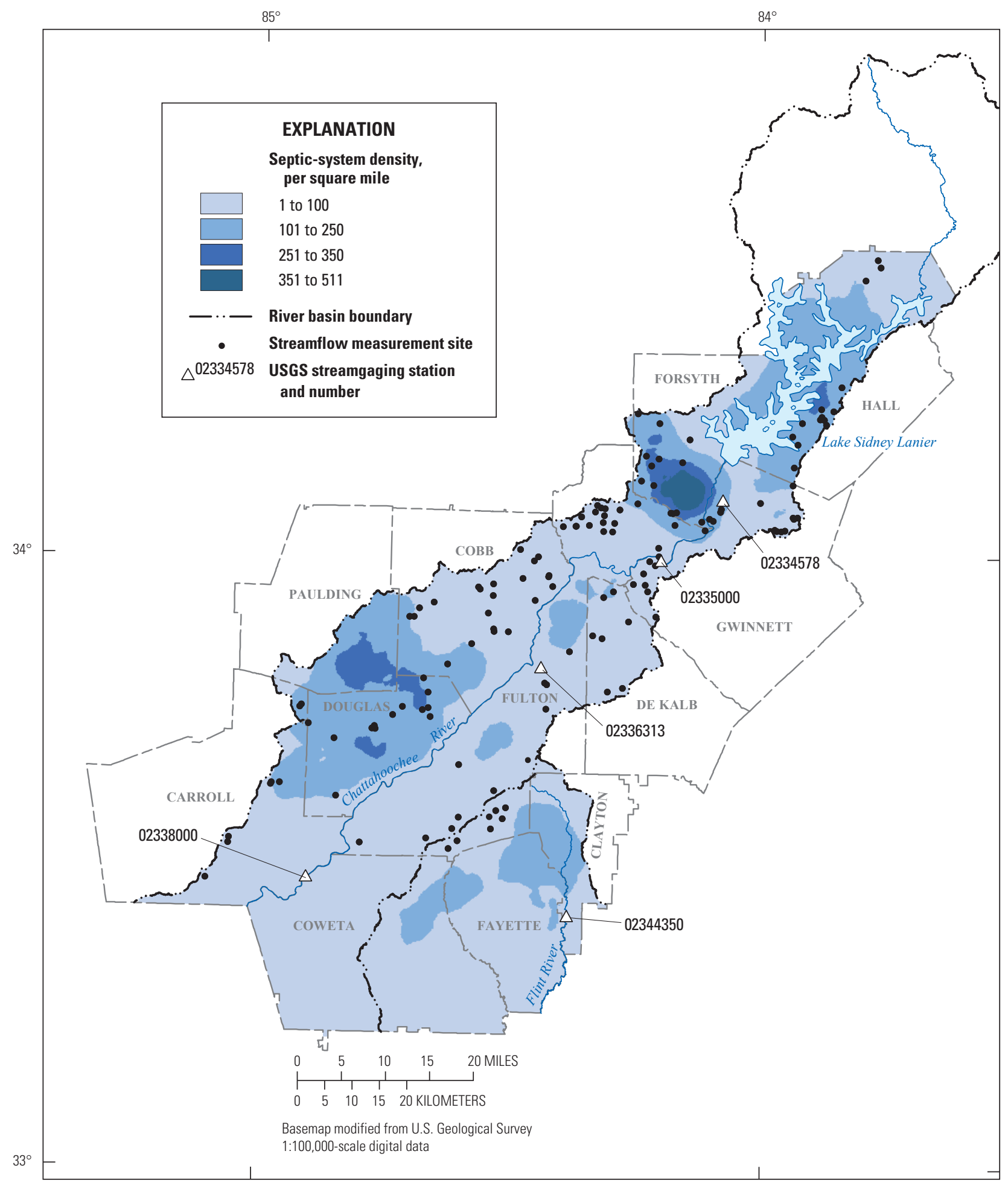

Figure 12. Septic system density in study area, 2012 (see table 2 for data sources). 


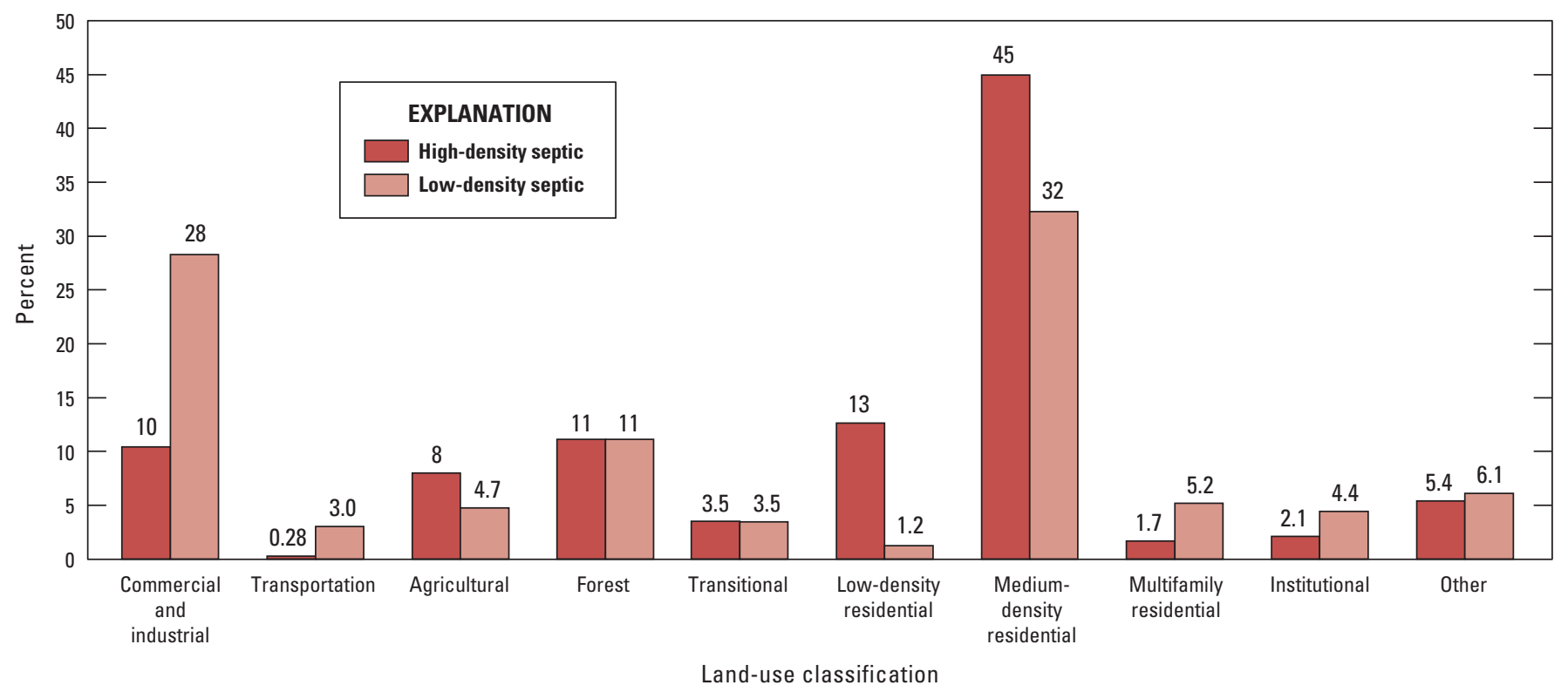

Figure 13. Land-use characteristics for basins with high and low density of septic systems in the study area, 2009 (data from Atlanta Regional Commission, 2009). 

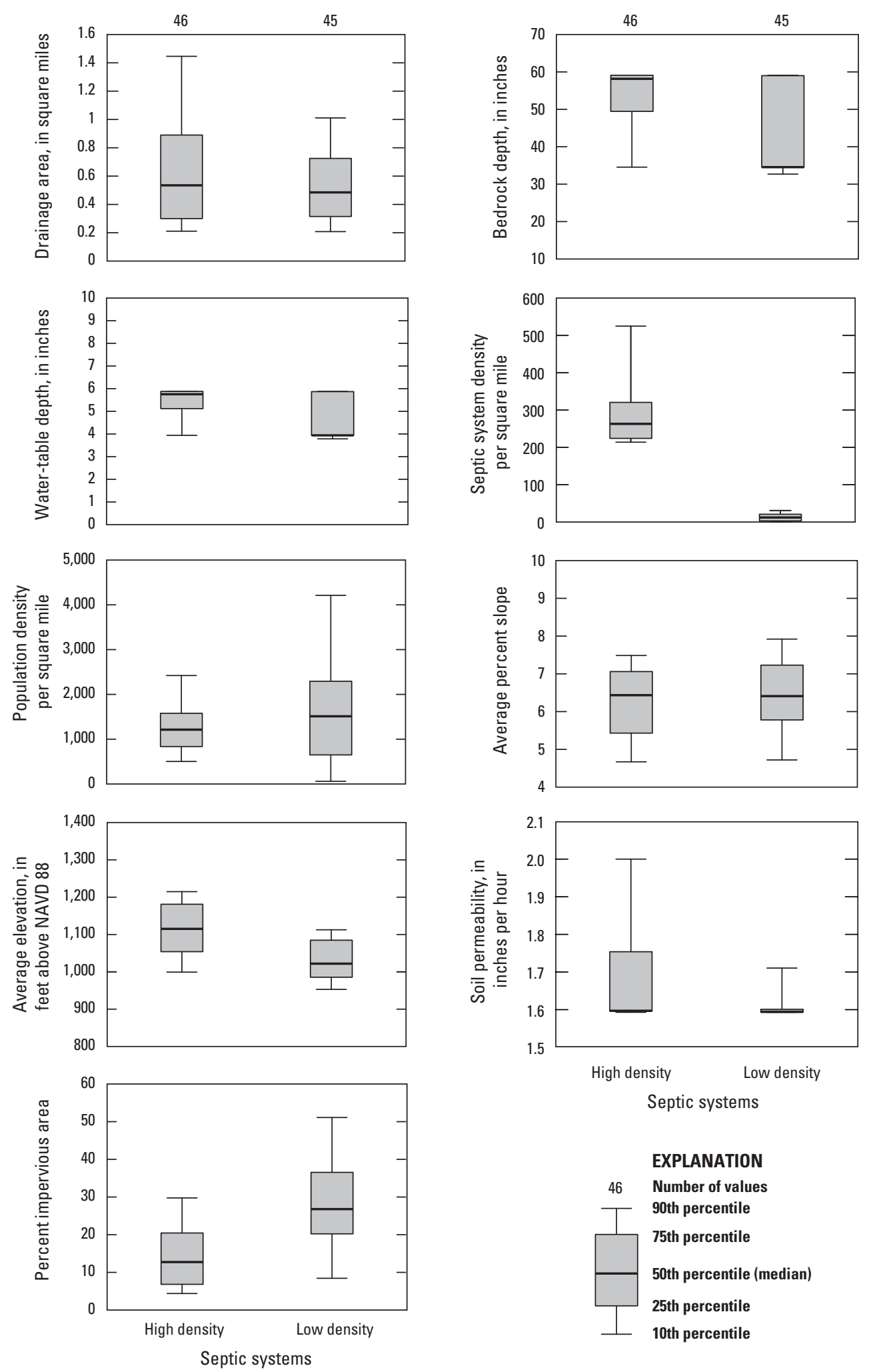

Figure 14. Boxplots showing drainage area, impervious area, and topographic and soil characteristics of basins with high and low density of septic systems in the study area. 


\section{Base Flow in September 2012}

Groundwater contribution to streamflow (base flow) was quantified using synoptic measurements at 133 ungaged sites and daily streamflow data from two gaged sites during drought conditions in September 10-13, 2012 (appendix 1). Of the 135 sites, 46 were in HDS basins, 45 in LDS basins, and 44 were in the middle range. Discharge, normalized for drainage area (base-flow yield) and expressed in cubic feet per second per square mile, ranged from 0 to $2.07 ; 39$ of the sites were dry. Of the 39 dry sites, 17 were in HDS basins, 15 in LDS basins, and 7 in middle range basins. Field water-quality measurements were collected at 94 of the 133 ungaged sites, including water temperature, specific conductance, dissolved oxygen, and $\mathrm{pH}$. The remaining 39 sites were dry and no water-quality measurement was possible. Water temperature ranged from 17.25 to $24.98{ }^{\circ} \mathrm{C}$; specific conductance ranged from 13 to 675 microsiemens per centimeter $(\mu \mathrm{S} / \mathrm{cm})$ at 25 degrees Celsius, dissolved oxygen ranged from 0.5 to 9.99 milligrams per liter $(\mathrm{mg} / \mathrm{L})$, and $\mathrm{pH}$ ranged from 5.57 to 9.34 . Figure 15 shows base-flow yield and selected water-quality properties for HDS and LDS sites to illustrate variations between the groups; data for middle range sites are not included but are listed in appendix 1.
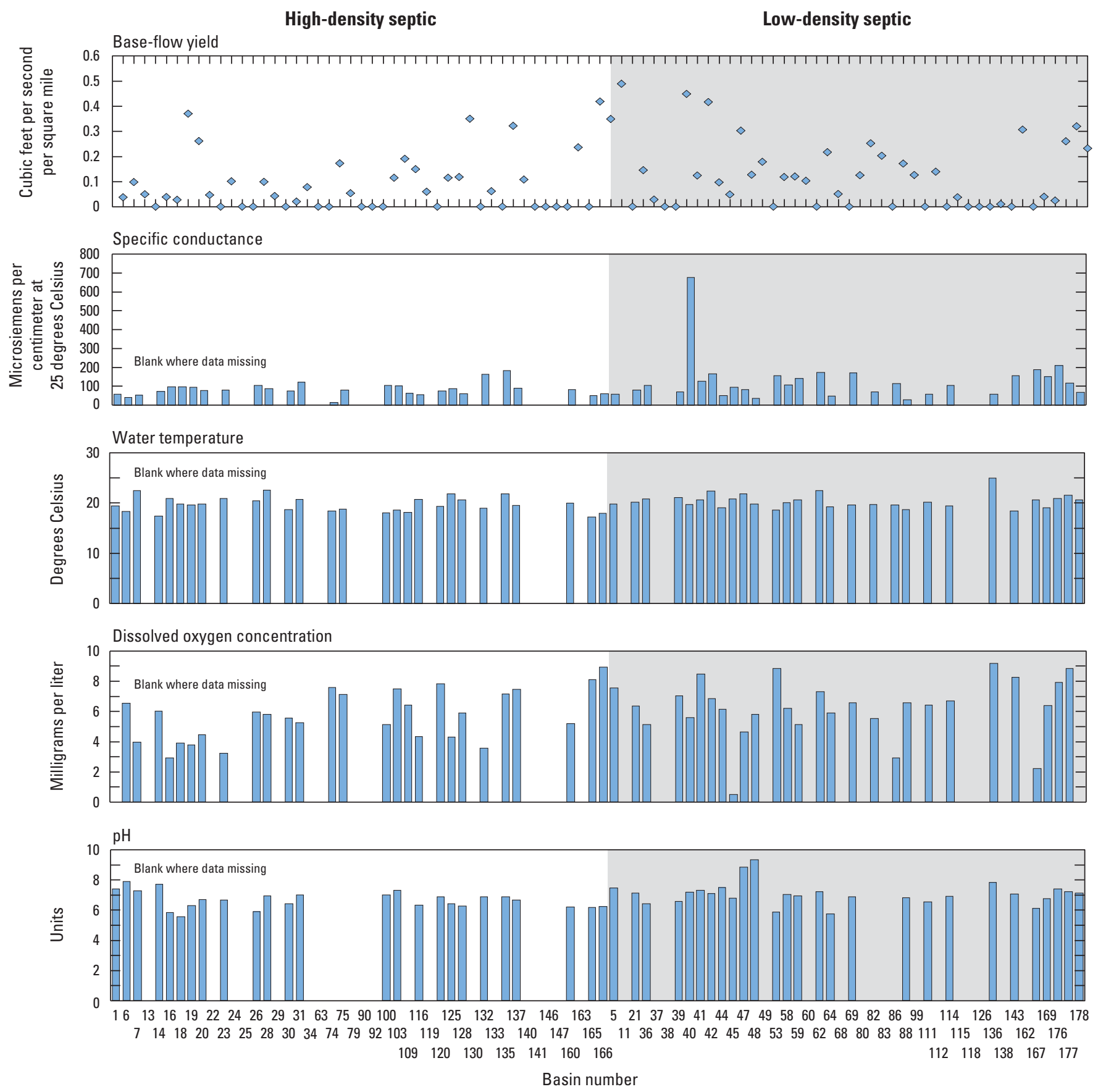

Figure 15. Base-flow yield and selected water-quality parameters in the study area, September 10-13, 2012. 
During the synoptic event, moderate to severe drought conditions existed in the northeastern part of the study area and extreme to exceptional drought conditions existed in the southwestern part (fig. 16). This variation creates differences in soil moisture and the amount of water available for evapotranspiration, as well as the amount of groundwater available for base flow to streams. During the synoptic event reported by Landers and Ankcorn (2008) in October 2007, all basins in their considerably smaller study area were experiencing more uniform conditions, namely severe drought.

Graphs showing daily precipitation and PET at Georgia Environmental Monitoring Network sites at Gainesville, Atlanta Airport, and Roopville for the week before and during the synoptic event (September 2-13, 2012) were plotted to provide information about climatic conditions throughout the study area (fig. 17). During the prior week of September 2-9, isolated rainfall events occurred at the three sites: September 3 at Gainesville and Roopville, September 6 at Roopville, and September 8 at all three sites. Average PET during September $2-14$ was -0.12 to -0.14 inch at the three sites. Net precipitation, the difference between rainfall and PET, was negative throughout the 2-week period, with the exception of the isolated rainfall events. Thus, streamflow measurements were made during a period of drought and high PET, with little water available for base flow to streams.

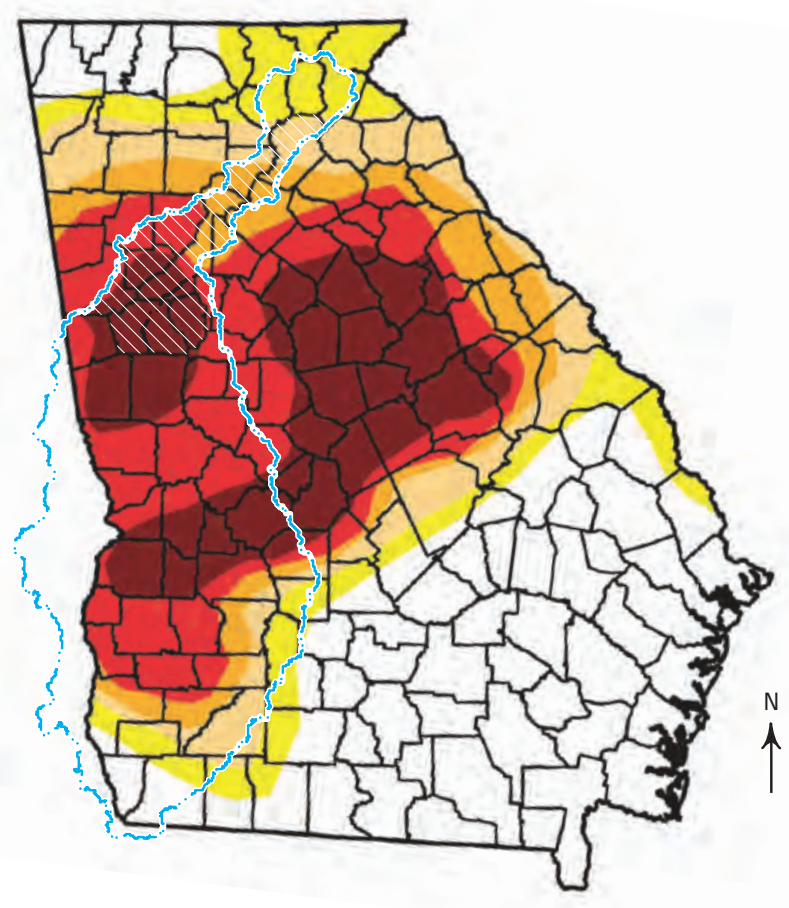

EXPLANATION

Intensity

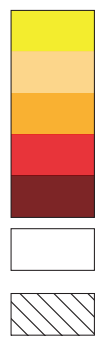

Abnormally dry

Drought-Moderate

Drought-Severe

Drought-Extreme

Drought-Exceptional

No drought

Study area

- -. - Apalachicola-Chattahoochee-Flint

River Basin boundary

Figure 16. Intensity of drought in Georgia, September 11, 2012 (modified from Drought Mitigation Center, 2013). 


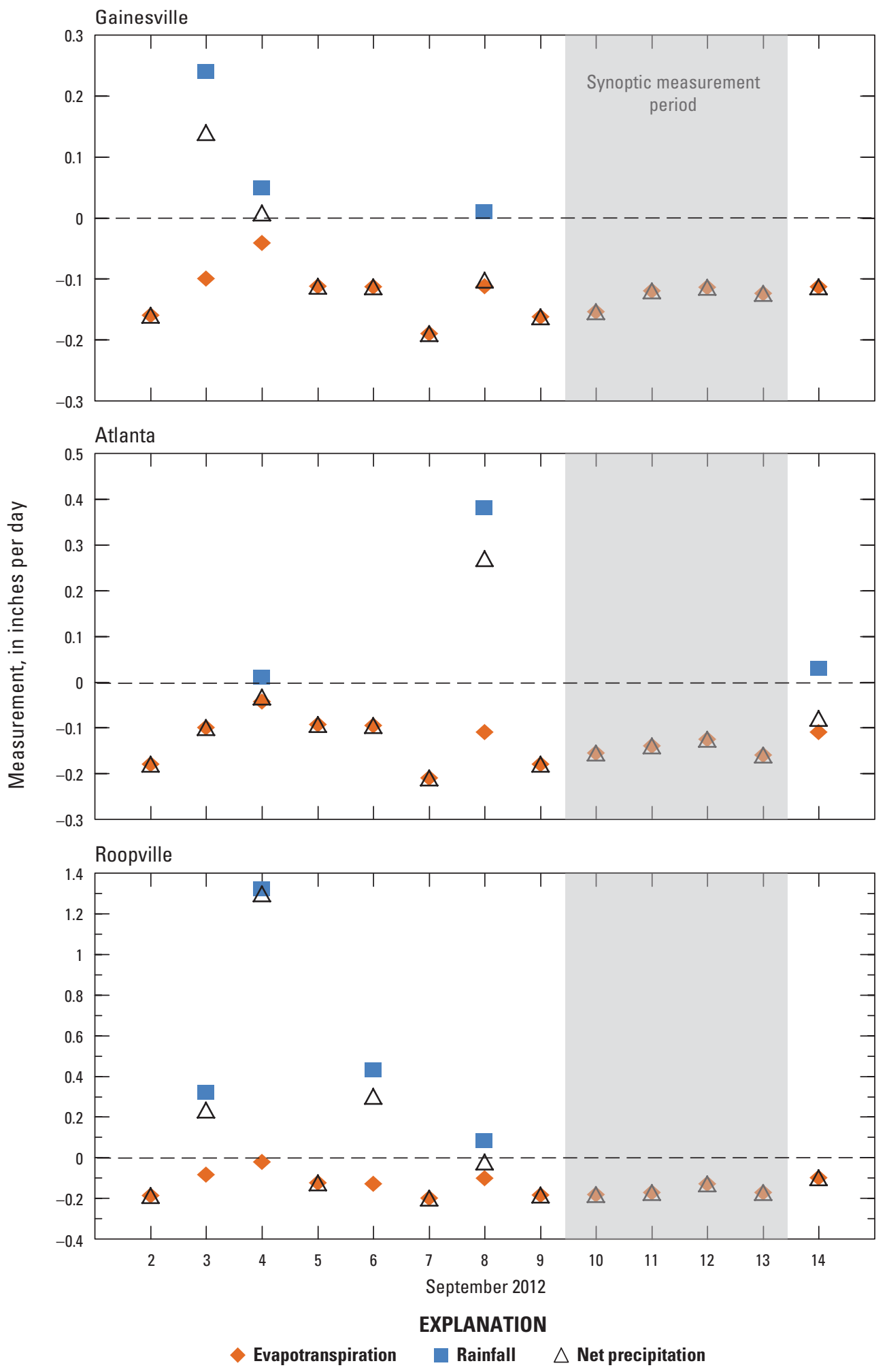

Figure 17. Daily total rainfall, potential evapotranspiration, and net precipitation at Georgia Environmental Monitoring Network sites at Gainesville, Atlanta, and Roopville, September 2-14, 2012. Net precipitation is the difference between precipitation and potential evapotranspiration. 


\section{Influence of Septic System Density}

Data were subdivided on the basis of HDS/LDS classification to assess the influence of septic systems on stream base flow (figs. 18 and 19, table 3). The median baseflow yield was $0.04\left(\mathrm{ft}^{3} / \mathrm{s}\right) / \mathrm{mi}^{2}$ for HDS sites, ranging from 0 to $0.42\left(\mathrm{ft}^{3} / \mathrm{s}\right) / \mathrm{mi}^{2}$, and $0.10\left(\mathrm{ft}^{3} / \mathrm{s}\right) / \mathrm{mi}^{2}$ for LDS sites, ranging from 0 to $0.49\left(\mathrm{ft}^{3} / \mathrm{s}\right) / \mathrm{mi}^{2}$. A Wilcoxon rank-sum test indicated the median base-flow yield was statistically the same, with a p-value of 0.345 (table 3 ).

Water-quality data were also compared on the basis of septic system density. The median of HDS and LDS samples for dissolved oxygen, stream temperature, and specific conductance were statistically the same, as indicated by results of a Wilcoxon rank-sum test (table 3). The median $\mathrm{pH}$ was
6.66 for HDS sites and 7.06 for LDS sites, and this difference was considered statistically significant based on a Wilcoxon rank-sum test (p-value 0.013).

Median specific conductance was $81 \mu \mathrm{S} / \mathrm{cm}$ for HDS sites, ranging from 13 to $183 \mu \mathrm{S} / \mathrm{cm}$, and $105 \mu \mathrm{S} / \mathrm{cm}$ for LDS sites, ranging from 29 to $675 \mu \mathrm{S} / \mathrm{cm}$ (table 3 ). A Wilcoxon rank-sum test of the median values of specific conductance from HDS and LDS sites also indicated that differences were insignificant ( $\mathrm{p}$-value 0.082).

Measurements collected in September 2012 did not indicate any statistically significant relation between septic system density and base-flow yield (fig. 20). Both data groups showed a poor best-fit line, with $\mathrm{r}^{2}$ values of 0.018 for HDS sites and 0.049 for LDS sites.
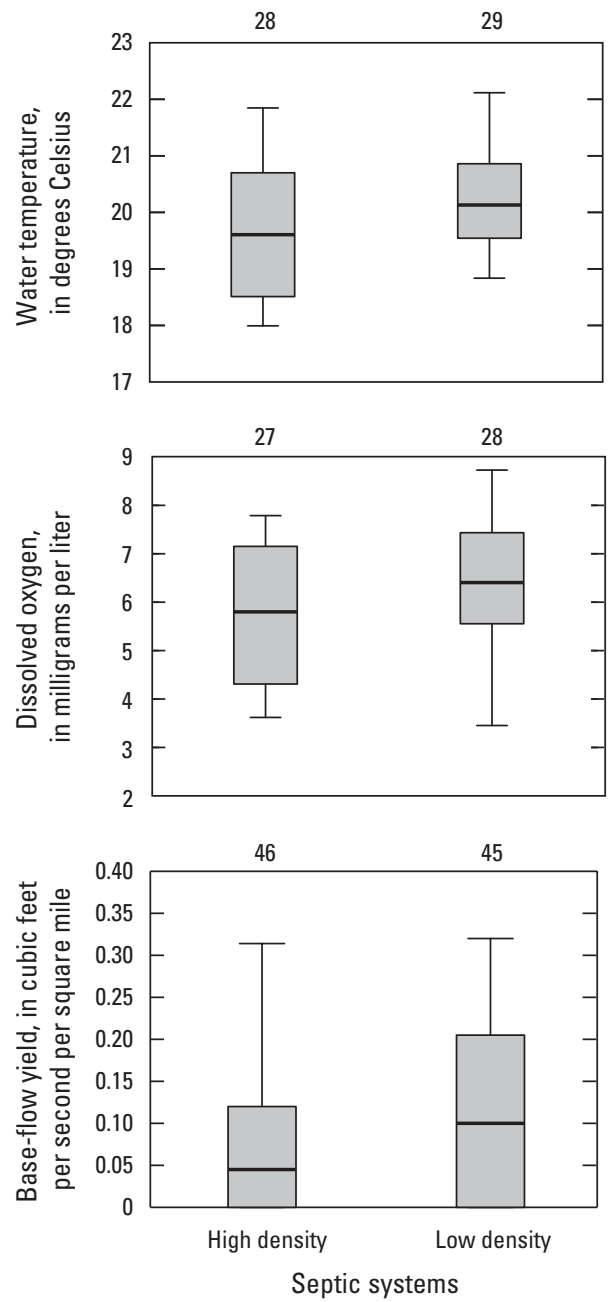
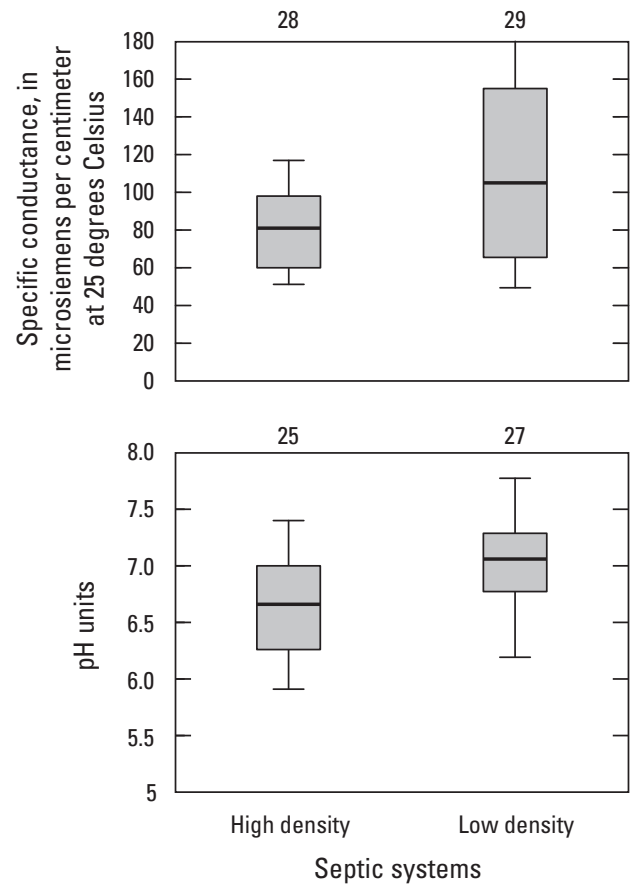

EXPLANATION

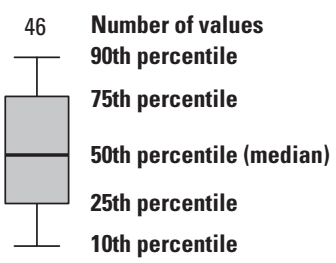

Figure 18. Boxplots showing base-flow yield and selected water-quality parameters of basins with high and low density of septic systems in the study area, September 10-13, 2012. 


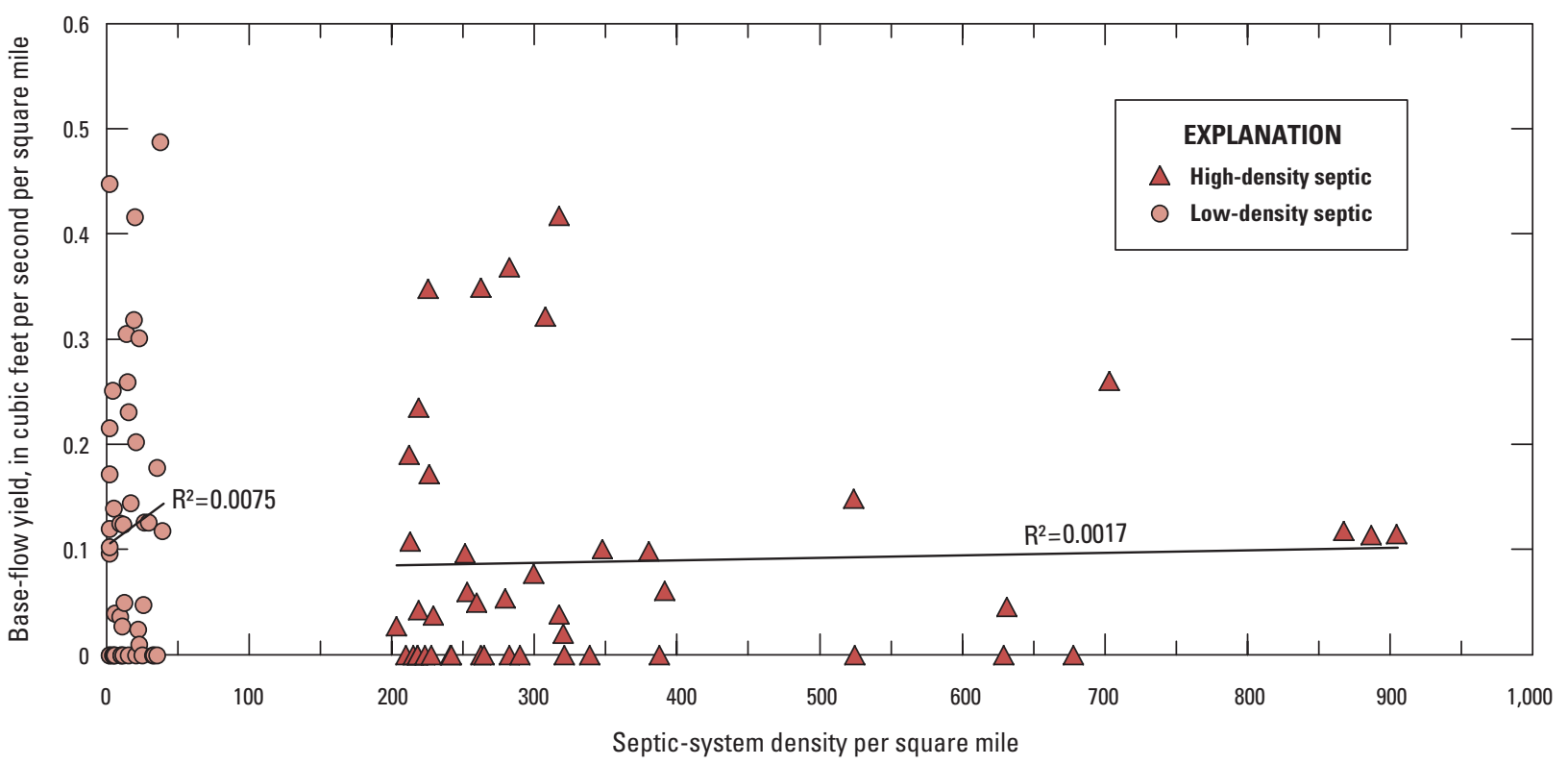

Figure 19. Base-flow yield and septic system density for basins with high and low density of septic systems in the study area, September 10-13, 2012.

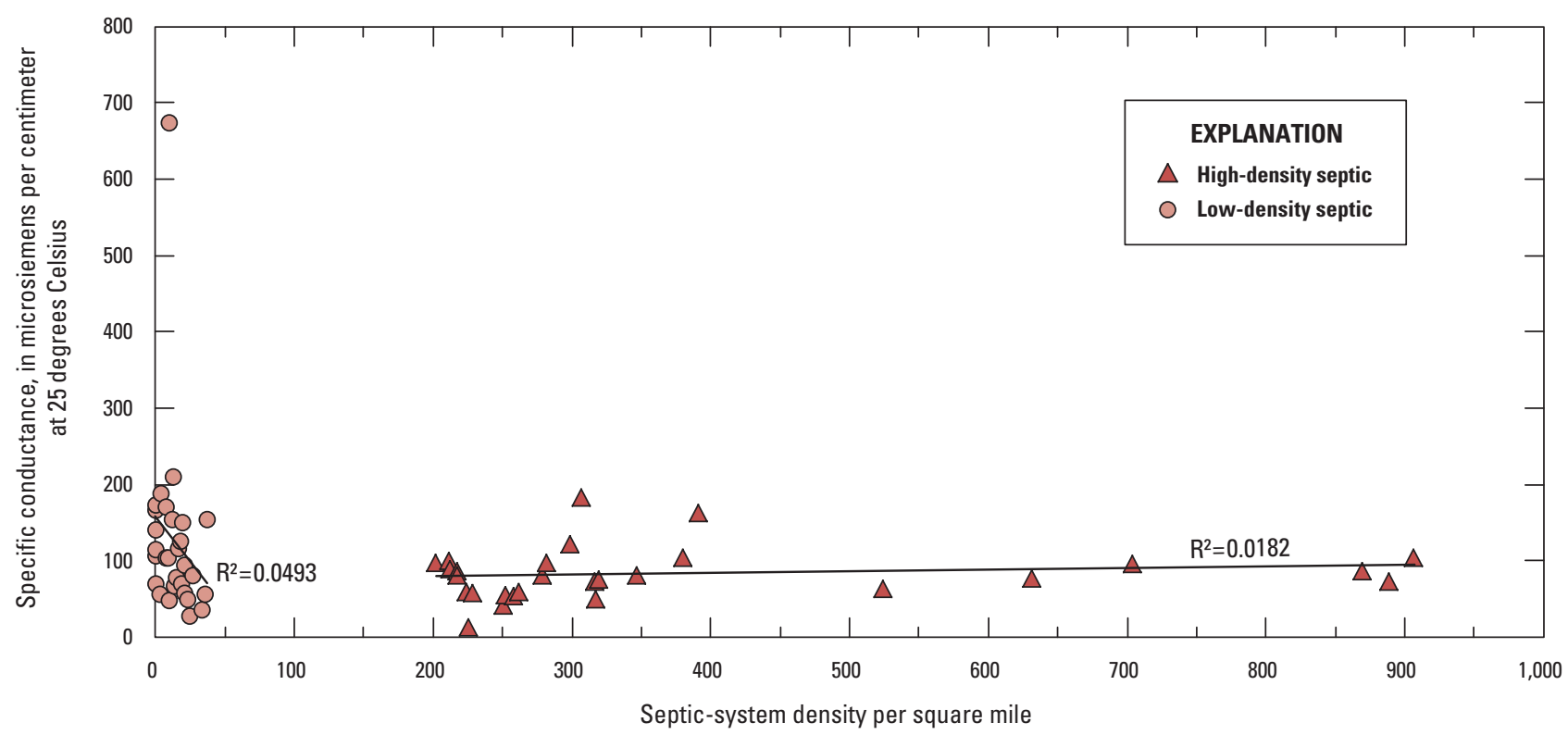

Figure 20. Specific conductance and septic system density for basins with high and low density of septic systems in the study area, September 10-13, 2012. 


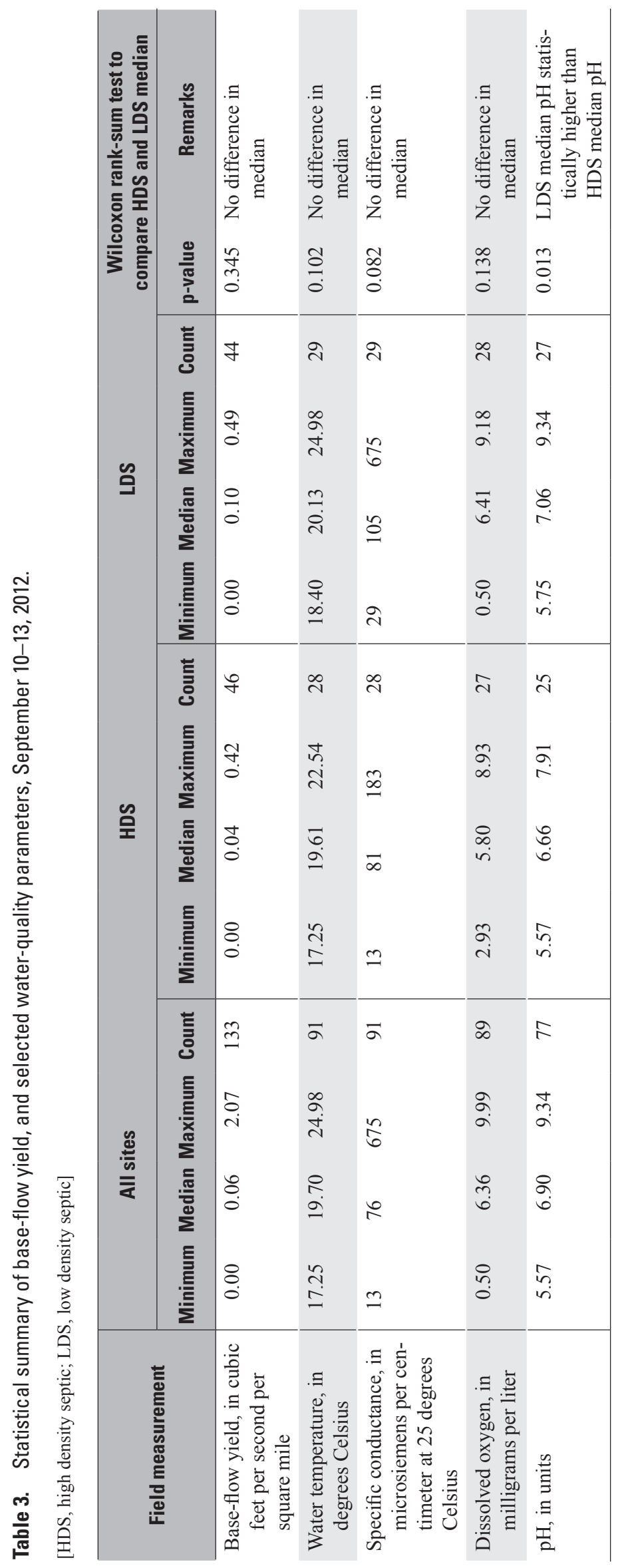




\section{Influence of Basin Characteristics}

Additional evaluations were completed to determine if there were other factors besides septic system density that may be influencing base flow in the HDS and LDS basins. A multiple linear regression was completed by culling zero streamflow values from the 133 ungaged sites measured in September 2012 (including HDS, LDS, and middle range sites) yielding a dataset of 94 sites. Base-flow yield was related to soil permeability, water-table depth, bedrock depth, percent impervious area, percent slope, septic density, average elevation, and population density (table 4). The resulting regression model showed a poor correlation between these parameters and base flow, with an adjusted $\mathrm{r}^{2}$ value of 0.07 . Table 4 includes a listing of the coefficients for each parameter; a positive coefficient indicates that an increase in a particular basin characteristic may result in an increase in base-flow yield, with the opposite response for a negative coefficient. Increased base-flow yield was associated with increased impervious area, bedrock depth, slope, and elevation; however, the only statistically significant parameters were percent impervious area and elevation, with p-values of 0.005 and 0.041 , respectively. The regression model indicated that septic system density was a statistically insignificant parameter, with a p-value of 0.328 .

Comparison of regression model (predicted) and observed base-flow yield and the difference in these values (residuals) were made (fig. 21). Predicted values are within 491 to -56 percent of observed values. In general, the model yields the poorest results at low base-flow yield values; residuals are greater than 100 percent for most values below $0.15\left(\mathrm{ft}^{3} / \mathrm{s}\right) / \mathrm{mi}^{2}$.

Table 4. Statistics for multiple linear regression model comparing base-flow yield to selected basin characteristics, September 10-13, 2012. Includes data from sites with high, middle, and low density of septic systems.

\begin{tabular}{lc}
\multicolumn{1}{c}{ Regression statistic } & Value \\
\hline Multiple r & 0.388 \\
r square & 0.150 \\
Adjusted r square & 0.070 \\
Standard error & 0.253 \\
Observations & 94 \\
\hline
\end{tabular}

\begin{tabular}{lcccc}
\multicolumn{1}{c}{ Parameter } & Coefficients & Standard error & t statistic & p-value \\
\hline Intercept & 12.1678 & 13.723 & 0.887 & 0.378 \\
Percent impervious area & 0.006217 & 0.00217 & 2.860 & 0.005 \\
Average elevation, in feet & 0.000635 & 0.00031 & 2.070 & 0.041 \\
Septic density per square mile & -0.000150 & 0.00015 & -0.984 & 0.328 \\
Bedrock depth, in inches & 0.640312 & 0.65589 & 0.976 & 0.332 \\
Water-table depth, in inches & -8.08779 & 8.3102 & -0.973 & 0.333 \\
Soil permeability, in inches per hour & -1.98238 & 2.2595 & -0.877 & 0.383 \\
Slope, in percent & 0.015310 & 0.02406 & 0.636 & 0.526 \\
Population density per square mile & 0.000009 & 0.00003 & 0.340 & 0.735 \\
\hline
\end{tabular}



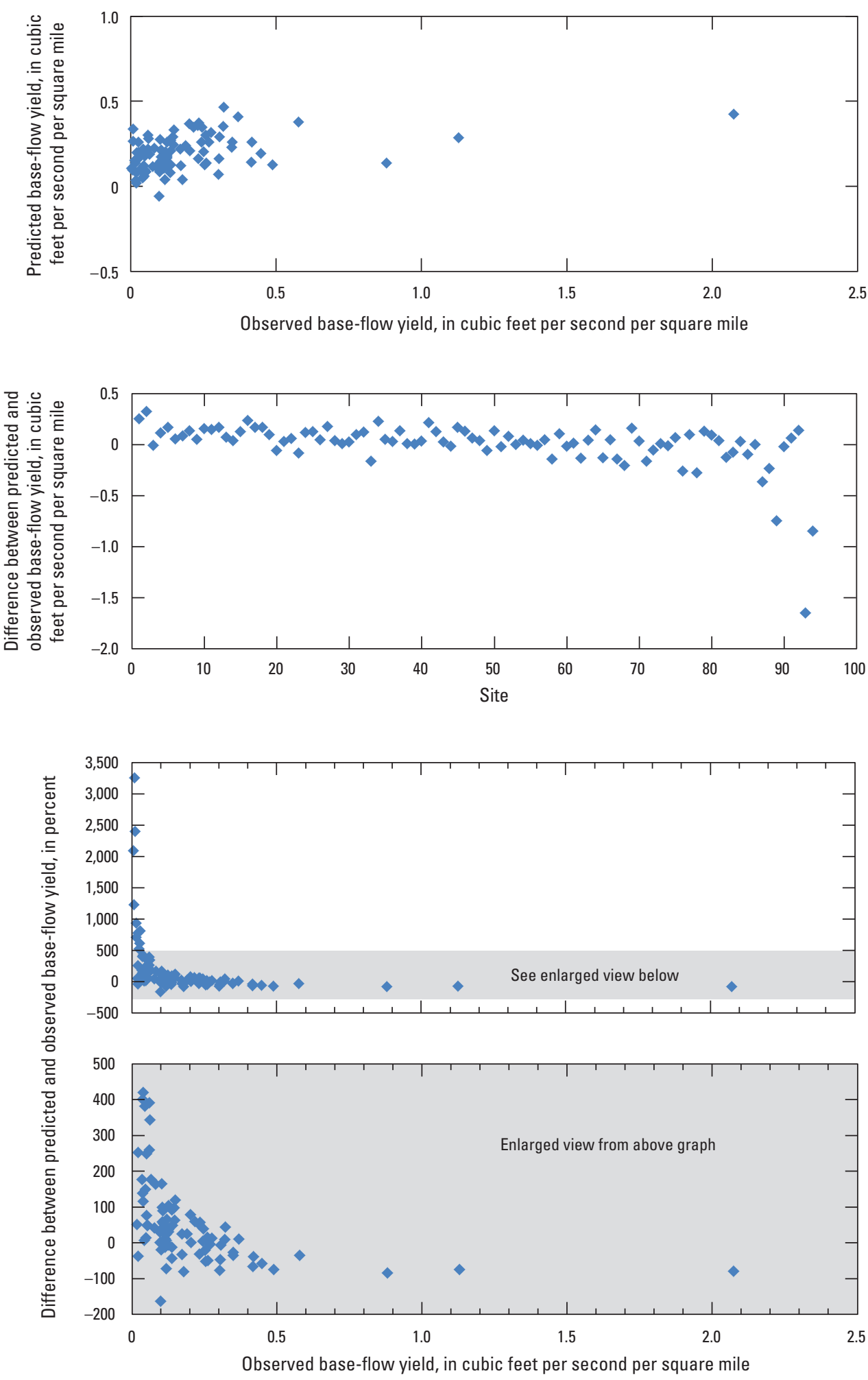

Figure 21. Predicted and observed base-flow yield and residuals for multiple linear regression model. 


\section{Influence of Geologic Area}

Data were subdivided on the basis of geologic area to see if any difference in base-flow yield could be discerned within an area having similar geology and geographic extent (fig. 22). The three geologic areas in the study area are the northern Piedmont, Brevard fault zone, and southern Piedmont. These areas also subdivide the study area on the basis of location relative to the Chattahoochee River: the northern Piedmont is located mostly north of the river and the southern Piedmont is generally south of the river, with the Brevard fault zone generally following the river's course between the northern and southern Piedmont areas (see locations, fig. 6). Basin characteristics within the three geologic areas are summarized in figure 23.
Between the three geologic areas, the following median basin characteristics were similar: elevation, slope, watertable depth, impervious percentage, soil permeability, and population density. Median bedrock depth was lowest in the northern Piedmont and higher and similar in the Brevard fault zone and southern Piedmont. Septic system density was greatest in the northern Piedmont, followed by the Brevard fault zone and southern Piedmont.

Median base-flow yield was statistically the same in the northern Piedmont and Brevard fault zone, and was higher in the southern Piedmont with values of 0.05 and $0.12\left(\mathrm{ft}^{3} / \mathrm{s}\right) / \mathrm{mi}^{2}$, respectively (fig. 24). Within each geologic area, base-flow yield in HDS and LDS basins was plotted and evaluated using a Wilcoxon rank-sum test (fig. 24, table 5). Within each of the three geologic areas, the median base-flow yield and specific conductance was statistically the same for HDS and LDS basins (table 5).

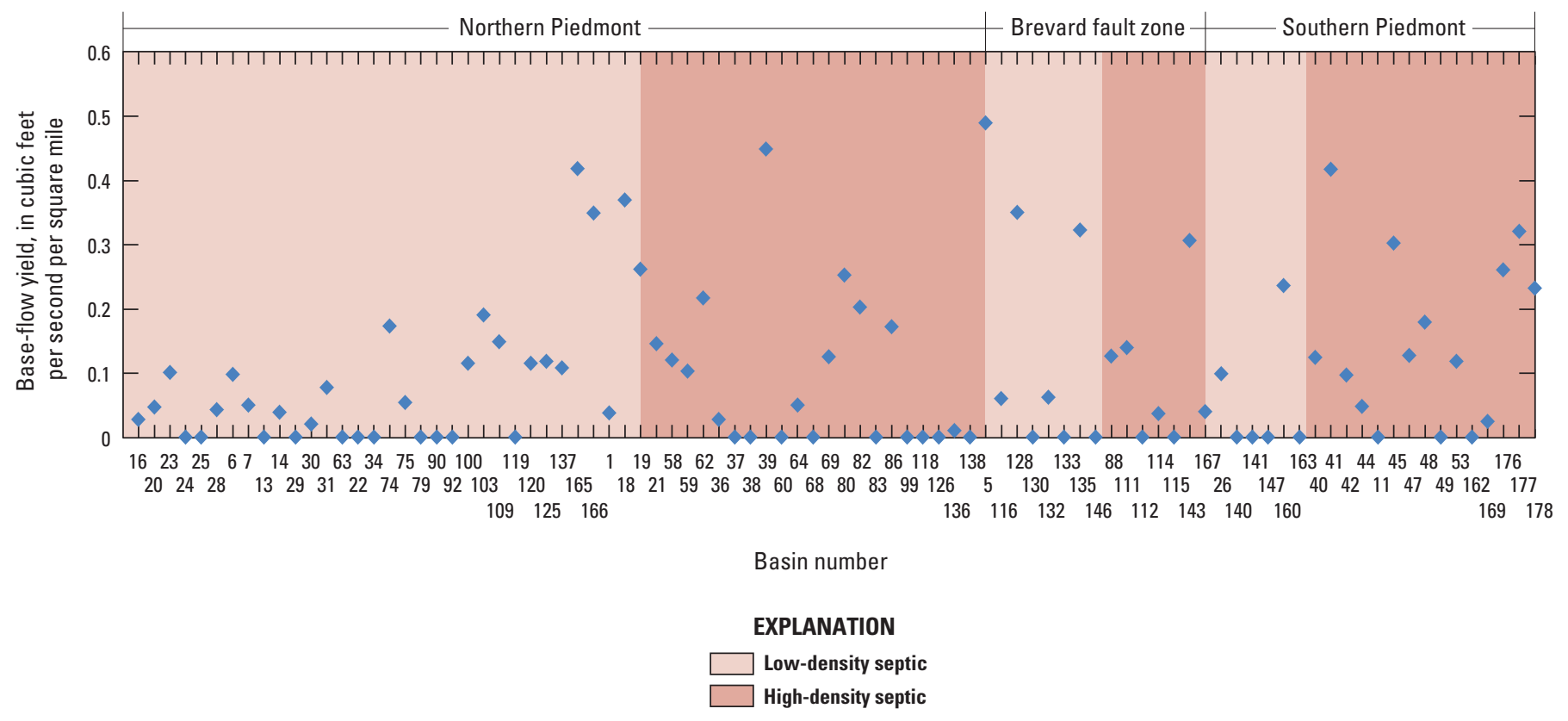

Figure 22. Base-flow yield by geologic area, September 10-13, 2012. 

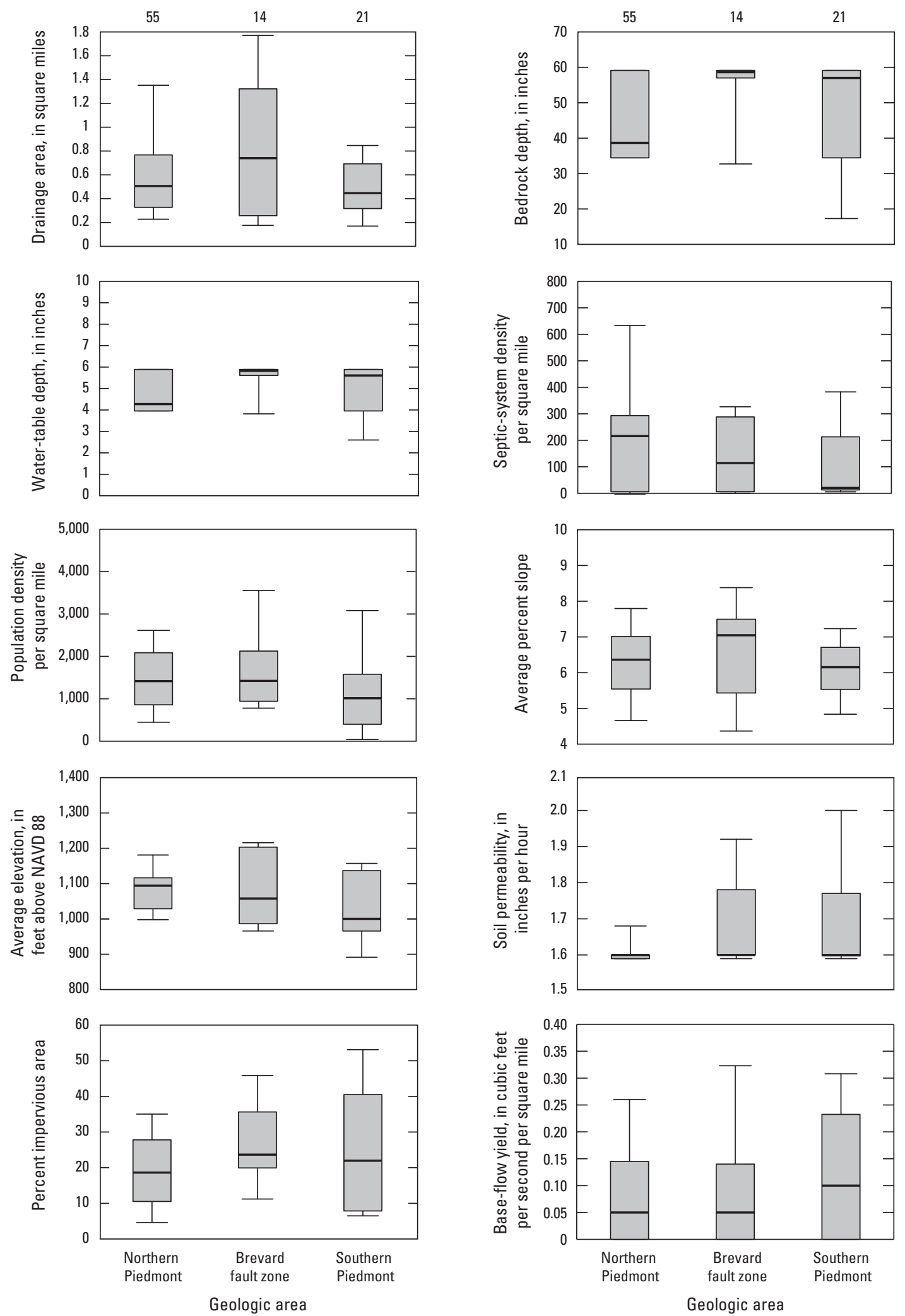

Figure 23. Boxplots showing base-flow yield, drainage area, impervious area, and topographic and soil characteristics of basins by geologic area. 
Table 5. Statistical summary of base-flow yield and specific conductance by geologic area, September 10-13, 2012.

[HDS, high density septic; LDS, low density septic]

\begin{tabular}{|c|c|c|c|c|c|c|c|c|c|c|}
\hline \multirow{3}{*}{ Geologic area } & \multicolumn{8}{|c|}{ Base-flow yield, in cubic feet per second per square mile } & \multicolumn{2}{|c|}{$\begin{array}{l}\text { Wilcoxon rank-sum test to } \\
\text { compare HDS and LDS } \\
\text { median values }\end{array}$} \\
\hline & \multicolumn{4}{|c|}{ HDS } & \multicolumn{4}{|c|}{ LDS } & \multirow{2}{*}{ p-value } & \multirow{2}{*}{ Remarks } \\
\hline & Minimum & Median & Maximum & Count & Minimum & Median & Maximum & Count & & \\
\hline Northern Piedmont & 0.00 & 0.05 & 0.42 & 33 & 0.00 & 0.04 & 0.49 & 22 & 0.888 & Medians same \\
\hline Brevard fault zone & 0.00 & 0.06 & 0.35 & 7 & 0.00 & 0.04 & 0.31 & 7 & 1.000 & Medians same \\
\hline
\end{tabular}

\begin{tabular}{|c|c|c|c|c|c|c|c|c|c|c|}
\hline \multirow{3}{*}{ Geologic area } & \multicolumn{8}{|c|}{ Specific conductance, in microsiemens per centimeter at 25 degrees Celsius } & \multicolumn{2}{|c|}{$\begin{array}{c}\text { Wilcoxon rank-sum test to } \\
\text { compare HDS and LDS } \\
\text { median values }\end{array}$} \\
\hline & \multicolumn{4}{|c|}{ HDS } & \multicolumn{4}{|c|}{ LDS } & \multirow{2}{*}{ p-value } & \multirow{2}{*}{ Remarks } \\
\hline & Minimum & Median & Maximum & Count & Minimum & Median & Maximum & Count & & \\
\hline Northern Piedmont & 13 & 79 & 122 & 22 & 49 & 92 & 174 & 12 & 0.2561 & Medians same \\
\hline Brevard fault zone & 56 & 111.5 & 183 & 4 & 29 & 105 & 189 & 5 & 0.9048 & Medians same \\
\hline
\end{tabular}
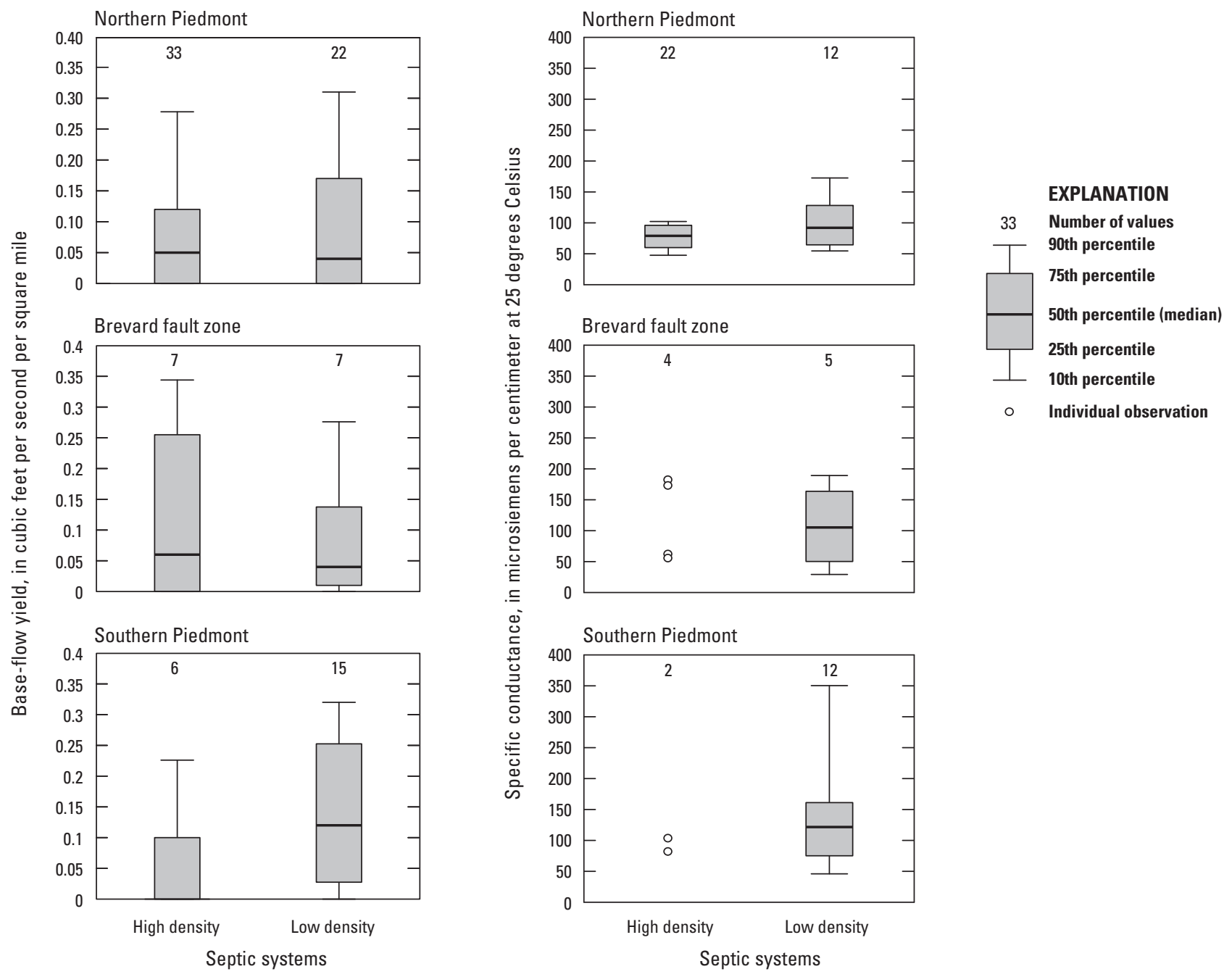

Figure 24. Boxplots showing base-flow yield and specific conductance by geologic area and septic system density. 


\section{Influence of Subareas}

Because base-flow measurements were collected over a large area of differing climatic, geologic, land use, and basin characteristics, data were subdivided into four areas to determine if septic system density may have an influence on base flow within areas of smaller extent (fig. 25). Smaller subareas may demonstrate more uniform basin characteristics, making comparison of HDS and LDS sites more appropriate. From northeast to southwest, the subareas are A, B, C, and D (see locations, fig. 1).

The four subareas had similar median percent slope and water table depth (fig. 26). Median soil permeability was higher in subarea A, with similar values in subareas B, C, and D. Median bedrock depth was similar in subareas A, B and D and was somewhat deeper in subarea $\mathrm{C}$. Elevation was highest in subarea A and similar in subareas B, C, and D. Population density was lowest in subarea D and similar in subareas A, $\mathrm{B}$, and $\mathrm{C}$. The percentage of impervious area was highest in subareas B and C and lowest in subarea D. Median septic system density was greatest in subarea A and about the same in subareas B, C, and D.

Median base-flow yield was highest in subarea D and lowest in subarea A (fig. 26). Within each of the subareas, base-flow yield and specific conductance were compared for HDS and LDS basins (fig. 27). With the exception of subarea B, base-flow yield was highest in basins with LDS; however, the difference was statistically insignificant as indicated by a Wilcoxon rank-sum test (table 6). Although median specific conductance was higher in LDS basins, this difference was also statistically insignificant as indicated by Wilcoxon rank-sum test results (table 6).

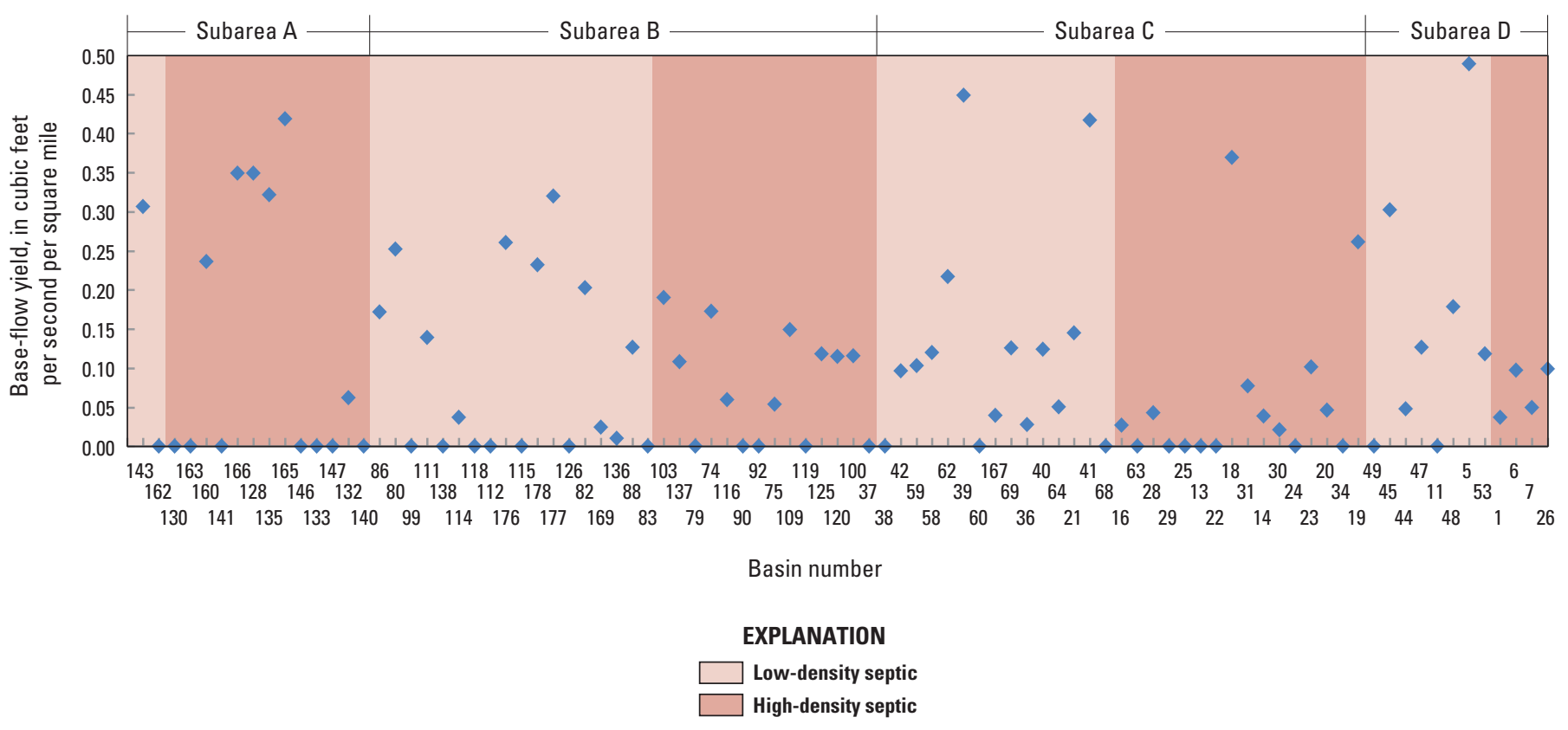

Figure 25. Base-flow yield by subarea, September 10-13, 2012. 

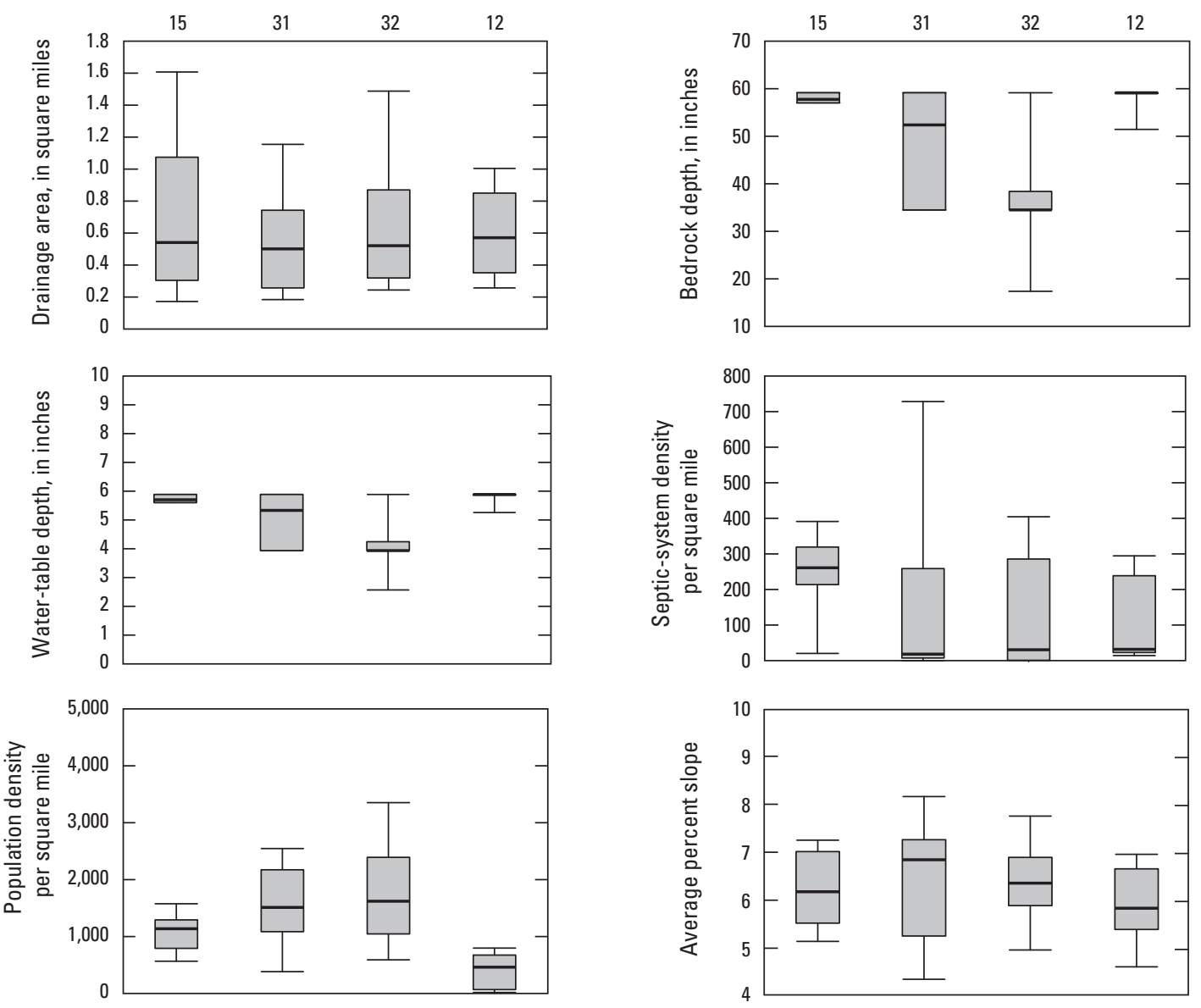

EXPLANATION

Number of values 90th percentile

75th percentile

50th percentile (median)

25th percentile

10th percentile
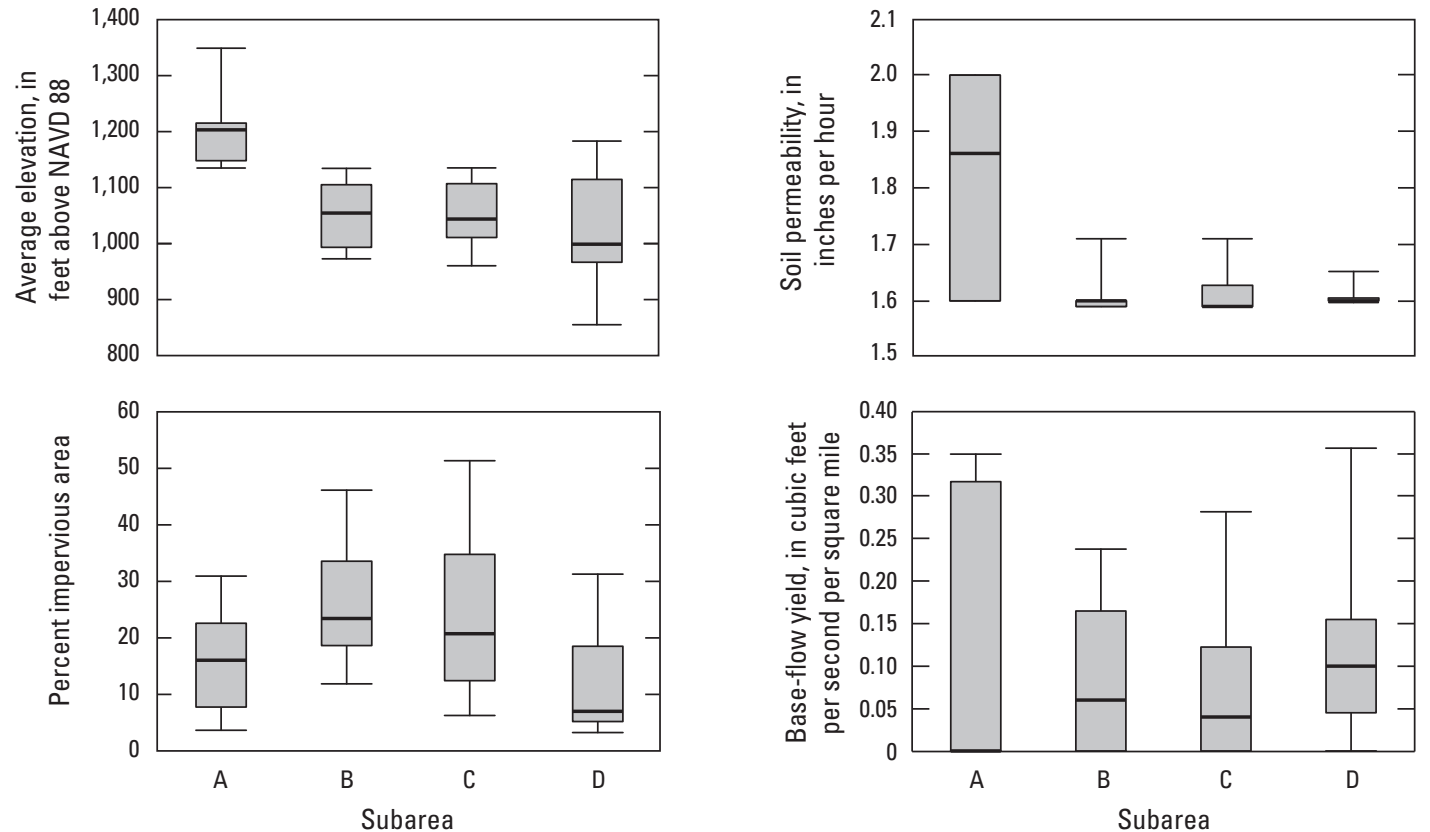

Figure 26. Boxplots showing base-flow yield, drainage area, impervious area, and topographic and soil characteristics of basins by subarea. 

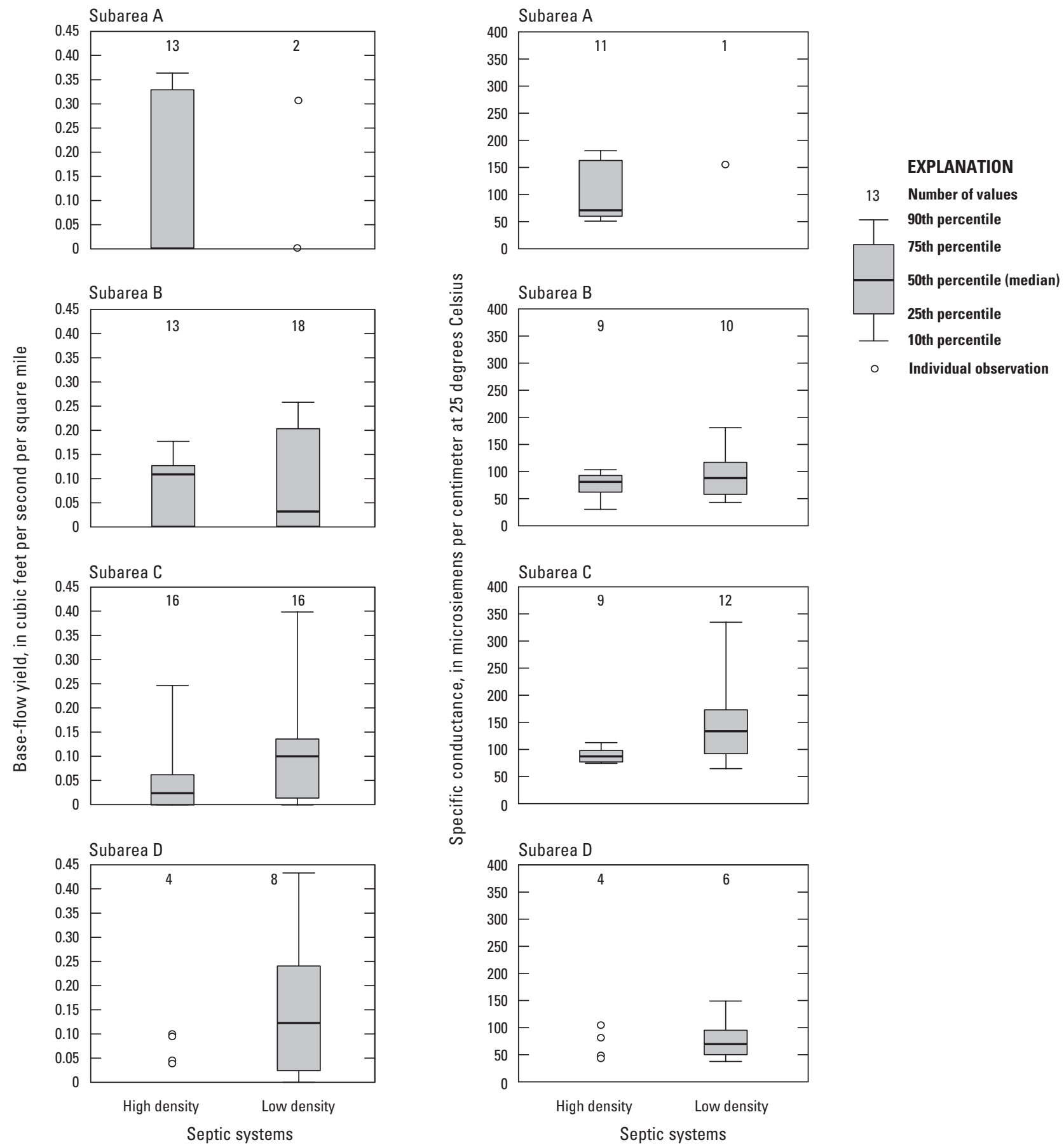

Figure 27. Boxplots showing base-flow yield and specific conductance by subarea and septic system density. 
Table 6. Statistical summary of base-flow yield and specific conductance by subarea, September 10-13, 2012.

[HDS, high density septic; LDS, low density septic]

\begin{tabular}{|c|c|c|c|c|c|c|c|c|c|c|}
\hline \multirow{3}{*}{ Subarea } & \multicolumn{8}{|c|}{ Base-flow yield (cubic feet per second per square mile) } & \multicolumn{2}{|c|}{$\begin{array}{l}\text { Wilcoxon rank-sum test to } \\
\text { compare HDS and LDS } \\
\text { median values }\end{array}$} \\
\hline & \multicolumn{4}{|c|}{ HDS } & \multicolumn{4}{|c|}{ LDS } & \multirow{2}{*}{ p-value } & \multirow{2}{*}{ Remarks } \\
\hline & Minimum & Median & Maximum & Count & Minimum & Median & Maximum & Count & & \\
\hline A & 0.00 & 0.00 & 0.42 & 13 & 0.00 & 0.15 & 0.31 & 2 & 1.000 & Medians same \\
\hline B & 0.00 & 0.11 & 0.19 & 13 & 0.00 & 0.03 & 0.32 & 18 & 0.854 & Medians same \\
\hline $\mathrm{D}$ & 0.04 & 0.07 & 0.10 & 4 & 0.00 & 0.12 & 0.49 & 8 & 0.444 & Medians same \\
\hline
\end{tabular}

\begin{tabular}{|c|c|c|c|c|c|c|c|c|c|c|}
\hline \multirow{2}{*}{ Subarea } & \multicolumn{8}{|c|}{ Specific conductance (microsiemens per centimeter at 25 degrees Celsius) } & \multicolumn{2}{|c|}{$\begin{array}{c}\text { Wilcoxon rank-sum test to } \\
\text { compare HDS and LDS } \\
\text { median values }\end{array}$} \\
\hline & Minimum & Median & Maximum & Count & Minimum & Median & Maximum & Count & p-value & Remarks \\
\hline A & 29 & 71 & 183 & 11 & 155 & 155 & 155 & 1 & 0.176 & Medians same \\
\hline $\mathrm{B}$ & 13 & 81 & 105 & 9 & 29 & 88 & 211 & 10 & 0.414 & Medians same \\
\hline $\mathrm{D}$ & 42 & 56 & 104 & 4 & 36 & 70 & 155 & 6 & 0.931 & Medians same \\
\hline
\end{tabular}




\section{Influence of Septic System Density in the Riparian Zone}

The riparian zone is typically an area of groundwater discharge and may have high rates of evapotranspiration because of the abundance of vegetation and trees near streams (fig. 11). In such areas, septic percolation may have a more direct pathway to provide base flow to streams. To evaluate the influence of septic systems in and near the riparian zone, a 45 -meter (147.6ft) buffer surrounding streams in each watershed was delineated and land use, soil, geologic, and topographic conditions within this area were computed using GIS and compared on the basis of HDS or LDS (fig. 28). Within these buffer zones, there were from 0 to 37 septic systems, with a density ranging from 0 to 560 systems $/ \mathrm{mi}^{2}$. The density of septic systems within the buffer zone were classified using a scheme similar to the that used for the entire study area: septic system density above the 66th percentile was classified as HDS, and septic system density below the 33 rd percentile was classified as LDS. Using this approach, HDS ranged from 34 to 560 systems $/ \mathrm{mi}^{2}$, and LDS was classified as 0 systems $/ \mathrm{mi}^{2}$.
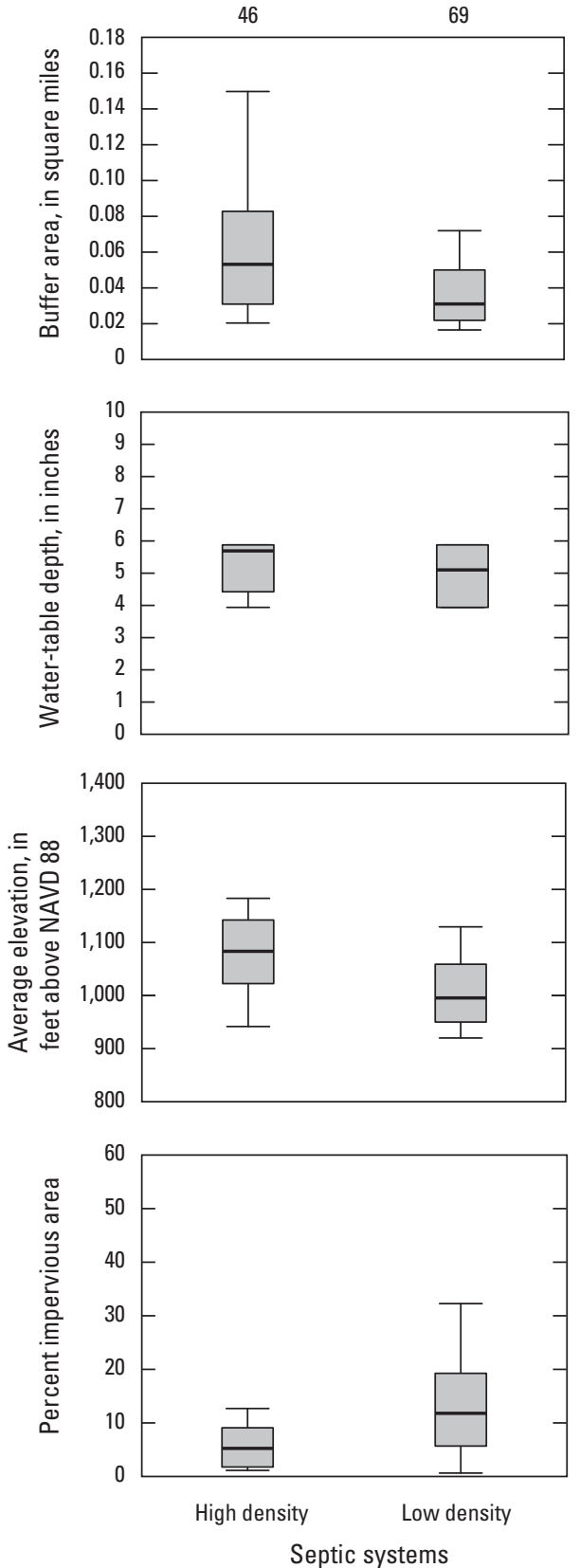
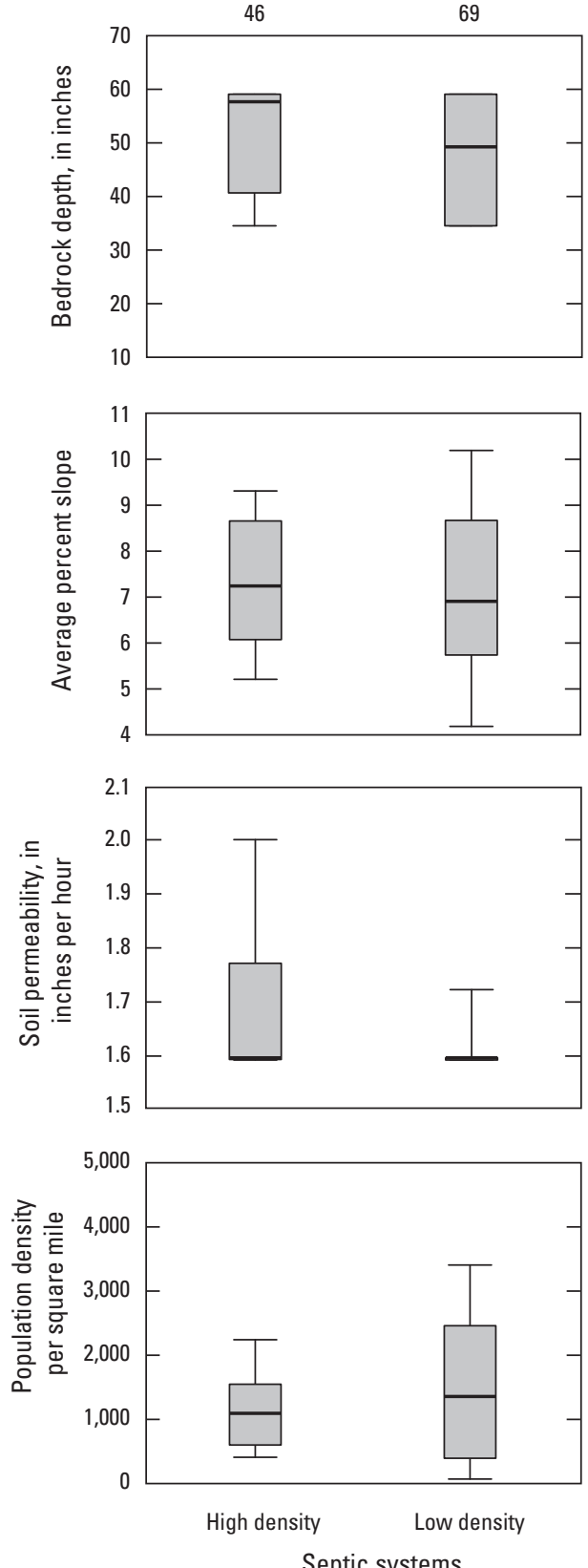

Septic systems
EXPLANATION

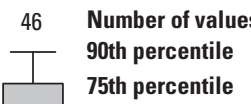

75th percentile

50th percentile (median)

25th percentile

Figure 28. Boxplots showing drainage area, impervious area, and topographic and soil characteristics within the 45 -meter buffer by septic system density. 
Within the 45-meter buffer zone, median population density and the percentage of impervious area was higher in LDS areas (fig. 28), which would be expected in more urban settings. The median of all other characteristics were either the same or greater in HDS buffer zones. Base-flow yield and specific conductance was greater in LDS buffer areas (fig. 29); however, the difference was statistically insignificant, as indicated by results of a Wilcoxon rank-sum test with p-values greater than 0.05 (table 7).

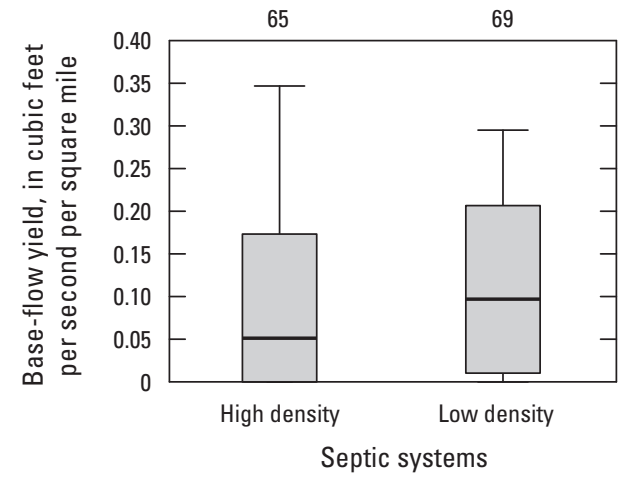

Figure 29. Boxplots showing baseflow yield and specific conductance within the 45-meter buffer zone by septic system density.

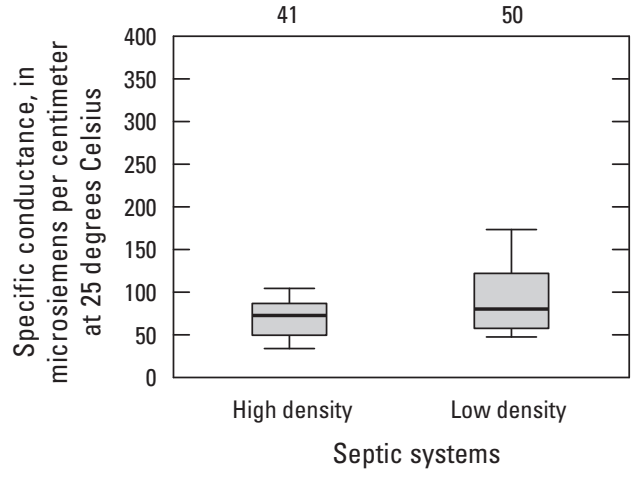

EXPLANATION

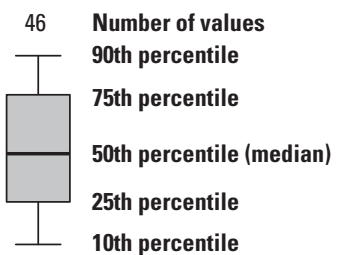

Table 7. Statistical summary of base-flow yield within 45-meter buffer zone for areas with high and low density of septic systems, September 10-13, 2012.

[HDS, high density septic; LDS, low density septic]

\begin{tabular}{|c|c|c|c|c|c|c|c|c|c|c|}
\hline \multirow[t]{2}{*}{$\begin{array}{c}\text { Field } \\
\text { measurement }\end{array}$} & \multicolumn{4}{|c|}{ HDS } & \multicolumn{4}{|c|}{ LDS } & \multicolumn{2}{|c|}{$\begin{array}{c}\text { Wilcoxon rank-sum test } \\
\text { to compare HDS and LDS } \\
\text { median values }\end{array}$} \\
\hline & Minimum & Median & Maximum & Count & Minimum & Median & Maximum & Count & p-value & Remarks \\
\hline $\begin{array}{l}\text { Base-flow yield, in } \\
\text { cubic feet per second } \\
\text { per square mile }\end{array}$ & 0.00 & 0.05 & 1.13 & 65 & 0.00 & 0.10 & 2.07 & 69 & 0.058 & $\begin{array}{l}\text { No difference in } \\
\text { median }\end{array}$ \\
\hline
\end{tabular}




\section{Base-Flow Analysis of Continuous Streamflow Data}

Streamflow was evaluated at the Level Creek (02334578) and Woodall Creek (02336313) streamgages to determine amounts of base flow and runoff during 2011-12. The two sites are small watersheds that illustrate a range of basin characteristics and septic system density, as shown in figure 30 .

The Level Creek Basin (02334578) drains a 5.08- $\mathrm{mi}^{2}$ area (fig. 31) and is located in a more rural area with higher septic system density, average elevation, population density, rock depth, and water-table depth than the Woodall Creek Basin (02336313). The Woodall Creek Basin drains a 2.8- $\mathrm{mi}^{2}$ area (fig. 32) in an urban setting near downtown Atlanta and has a higher percentage of impervious area than Level Creek. Near
Level Creek, land use is primarily residential (61 percent) and forest (24 percent), whereas near Woodall Creek, land use is primarily industrial and commercial (51 percent) and transportation and highways (18 percent; fig. 30).

The two sites are located within different geologic areas. The Level Creek Basin is located in the northern Piedmont, and the Woodall Creek Basin is located within the southern Piedmont. In the septic system classification scheme developed for this study, the Level Creek Basin would be in the middle range, having a septic system density of 101 systems $/ \mathrm{mi}^{2}$ and thus falling between the 33rd and 66th percentile of septic system density (fig. 30). The Woodall Creek Basin is classified as an LDS site, having a septic system density of 18 systems $/ \mathrm{mi}^{2}$. Although Level Creek is considered in the middle range, its septic system density is 5.6 times greater than at Woodall Creek. 

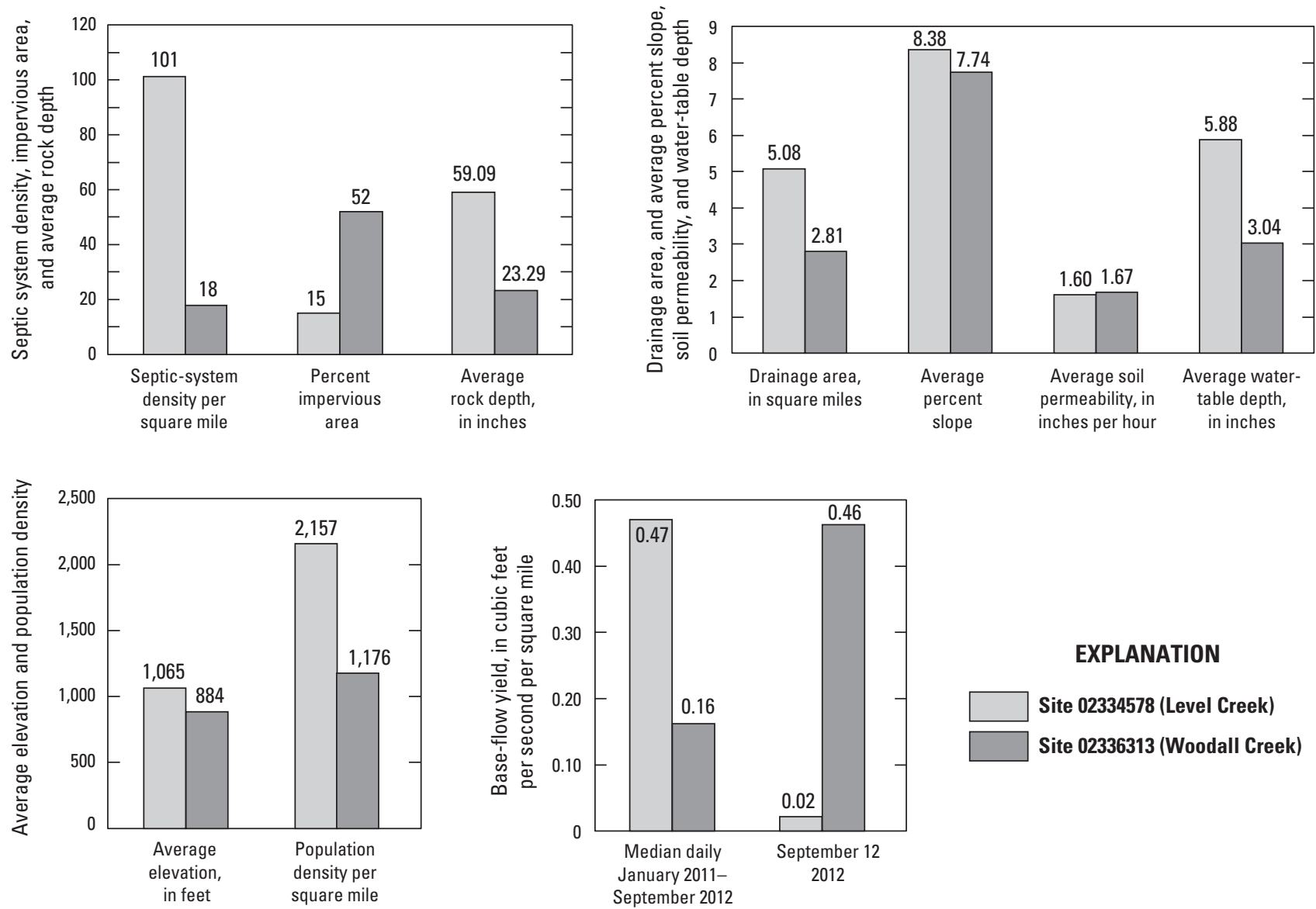

EXPLANATION

Site 02334578 (Level Creek)

Site 02336313 (Woodall Creek)

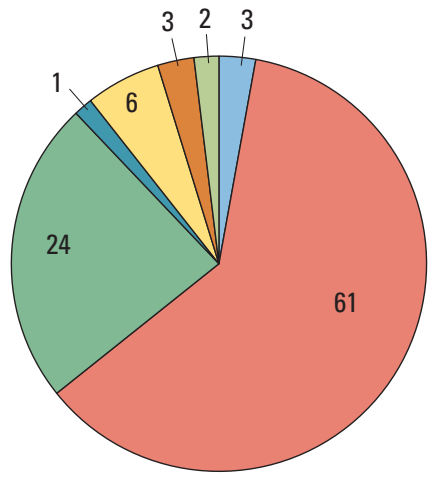

Level Creek Basin (Site 02334578)

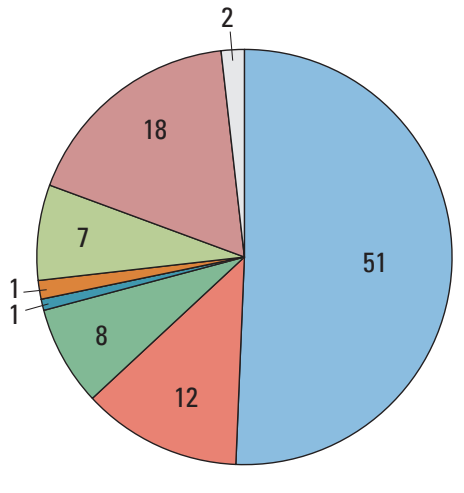

Woodall Creek Basin (Site 02236313)

\section{Land use, in percent}

Industrial and commercial

Residential

Forest

Institutional

Agricultural

Transitional

Golf courses, parks, and cemeteries

Transportation and highways

Other

Figure 30. Base-flow yield and basin characteristics of USGS site 02334578 Level Creek at Suwannee Dam Creek near Suwannee, GA, and USGS site 02336313 Woodall Creek at Defoors Ferry Road, at Atlanta, GA (see table 1 for data sources). 

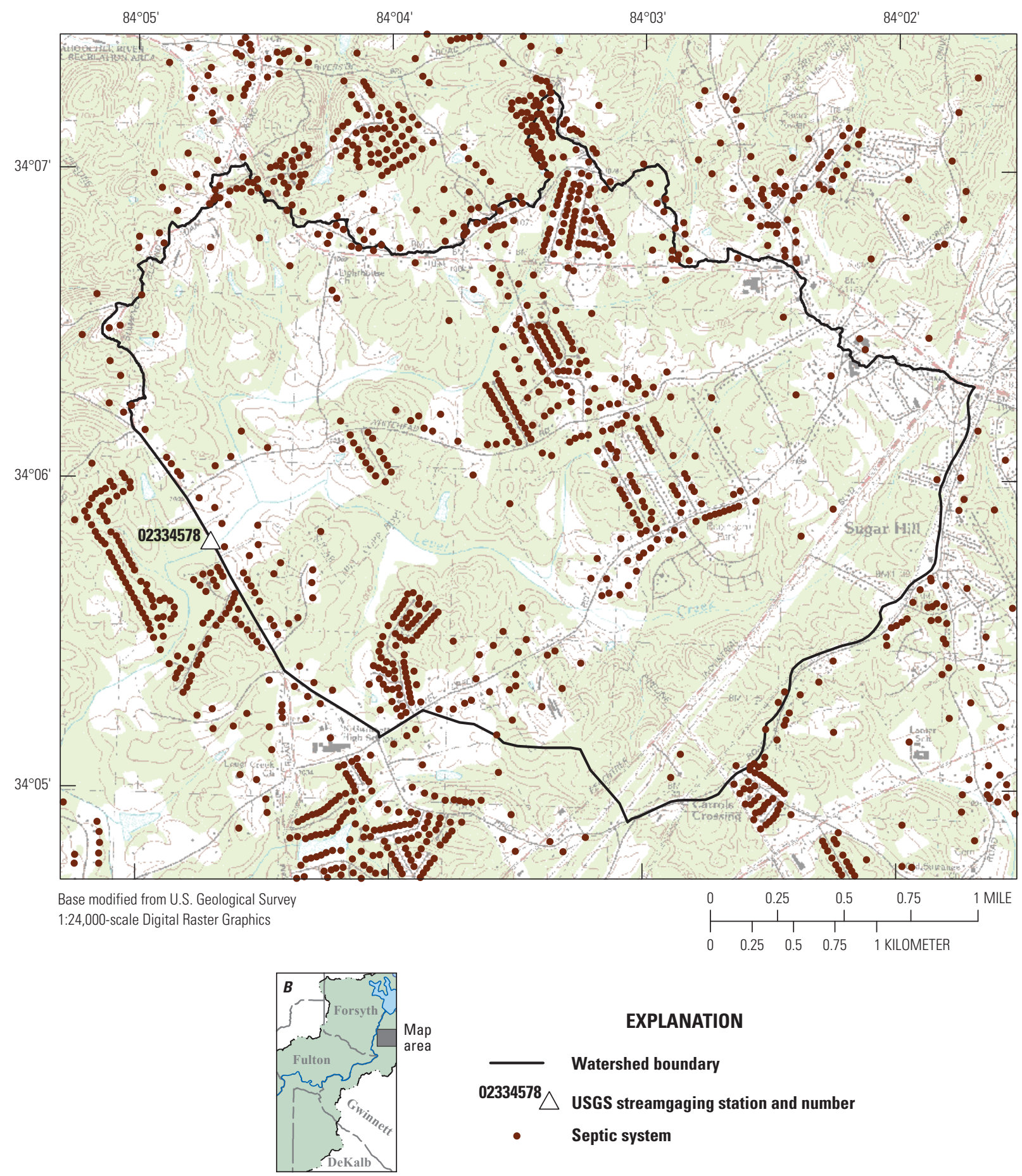

EXPLANATION

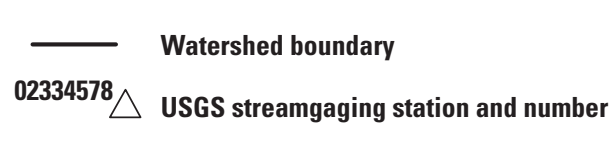

- $\quad$ Septic system

Figure 31. Drainage area and location of USGS site 02334578, Level Creek at Suwanee Dam Road near Suwanee, GA. 


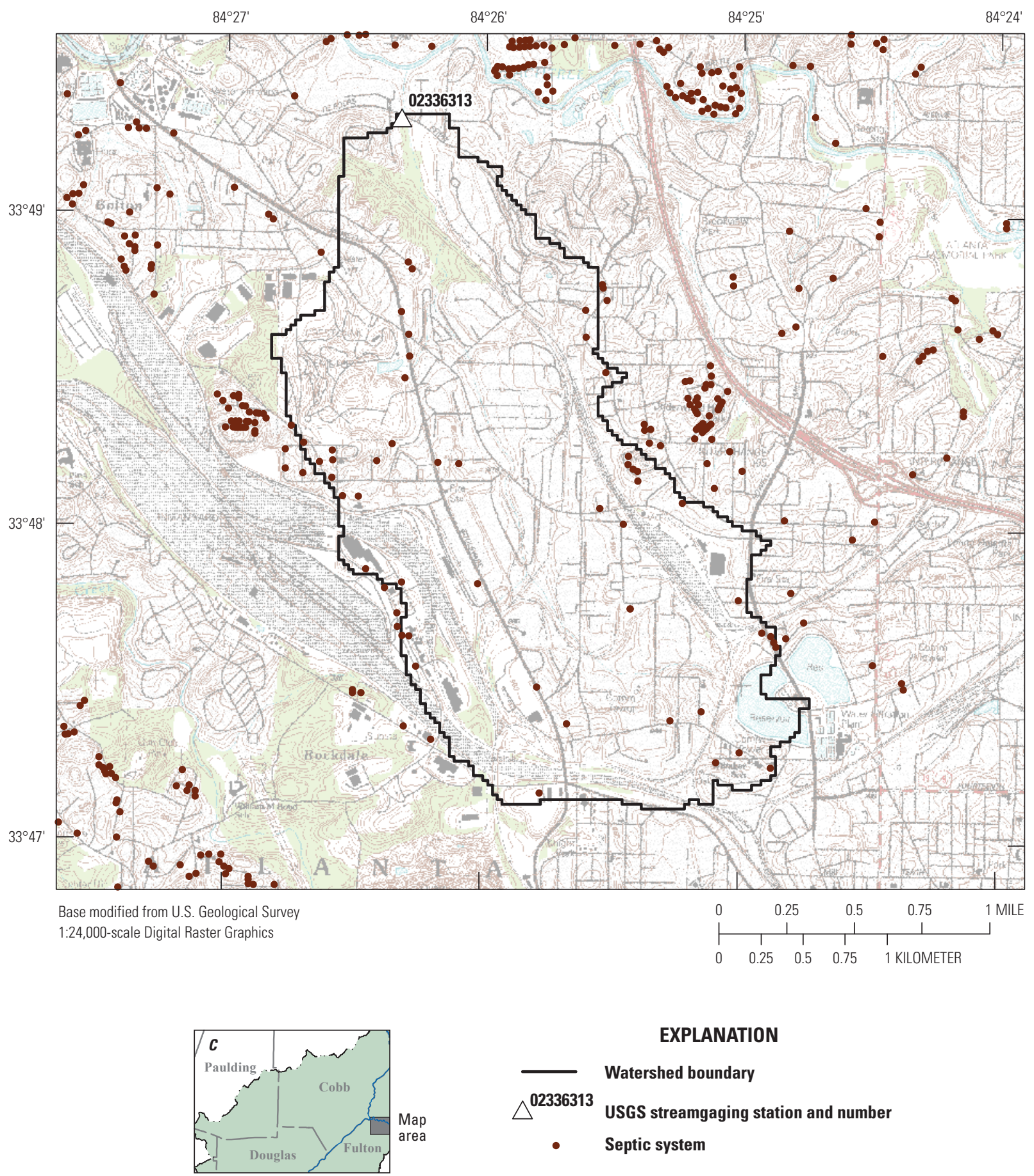

Figure 32. Drainage area and location of USGS site 02336313 , Woodall Creek at Defoors Ferry Road, at Atlanta, GA. 
To provide a more complete estimate of base flow at the two sites, daily streamflow data collected during 2011-12 were analyzed using the USGS computer program HYSEP (Sloto and Crouse, 1996). HYSEP separates streamflow hydrographs into base flow and runoff components, providing an indication of the percentage of total streamflow provided by base flow (fig. 33).

Daily mean base flow in the Level Creek Basin during January 2011-September 2012 ranged from 0.33 to $19 \mathrm{ft}^{3} / \mathrm{s}$, with a median of $2.4 \mathrm{ft}^{3} / \mathrm{s}$ (table 8 ). Normalizing these flows for drainage area, base-flow yield ranged from 0.07 to $3.8\left(\mathrm{ft}^{3} / \mathrm{s}\right) / \mathrm{mi}^{2}$ with a median of $0.48\left(\mathrm{ft}^{3} / \mathrm{s}\right) / \mathrm{mi}^{2}$. Base flow provided over 75 percent of total daily streamflow during most of the period (fig. 34).

Daily mean base flow in the Woodall Creek Basin during the same period ranged from 0.13 to $2.2 \mathrm{ft}^{3} / \mathrm{s}$ with a median of $0.43 \mathrm{ft}^{3} / \mathrm{s}$. Equivalent base-flow yield during 2011-12 ranged from 0.05 to $0.85\left(\mathrm{ft}^{3} / \mathrm{s}\right) / \mathrm{mi}^{2}$ with a median of $0.17\left(\mathrm{ft}^{3} / \mathrm{s}\right) / \mathrm{mi}^{2}$. Base flow provided over 75 percent of total streamflow during most of the year (fig. 34).
During 2011-12, base flow at each of the sites was highest in winter and lowest in the late summer and fall (fig. 33). Baseflow yield was highest in the Level Creek Basin, where flows exceeded $0.19\left(\mathrm{ft}^{3} / \mathrm{s}\right) / \mathrm{mi}^{2}$ over 90 percent of the time, compared to $0.07\left(\mathrm{ft}^{3} / \mathrm{s}\right) / \mathrm{mi}^{2}$ in the Woodall Creek Basin (table 8). Although other site factors may have some influence, the lower base-flow yield at Woodall Creek during 2011-12 may be accounted for, in part, by a 3.5-times greater percentage of impervious area and 5.6-times lower septic system density (fig. 30).

During the synoptic measurement effort on September 11-13, 2012, base-flow yield was over 20 times higher in the Woodall Creek Basin than in the Level Creek Basin, with values of 0.16 and $0.004\left(\mathrm{ft}^{3} / \mathrm{s}\right) / \mathrm{mi}^{2}$, respectively (appendix 2). The higher base-flow yield in the more urban Woodall Creek Basin was not expected, given its greater impervious area cover and lower septic system density (fig. 30). The reason for the higher base flow at Woodall Creek during this period is unknown; however, the more urban setting at Woodall Creek suggests that base flow could be enhanced by outside interferences such as pipe leakage or unreported surface-water discharges.

Site 02334578 (Level Creek)

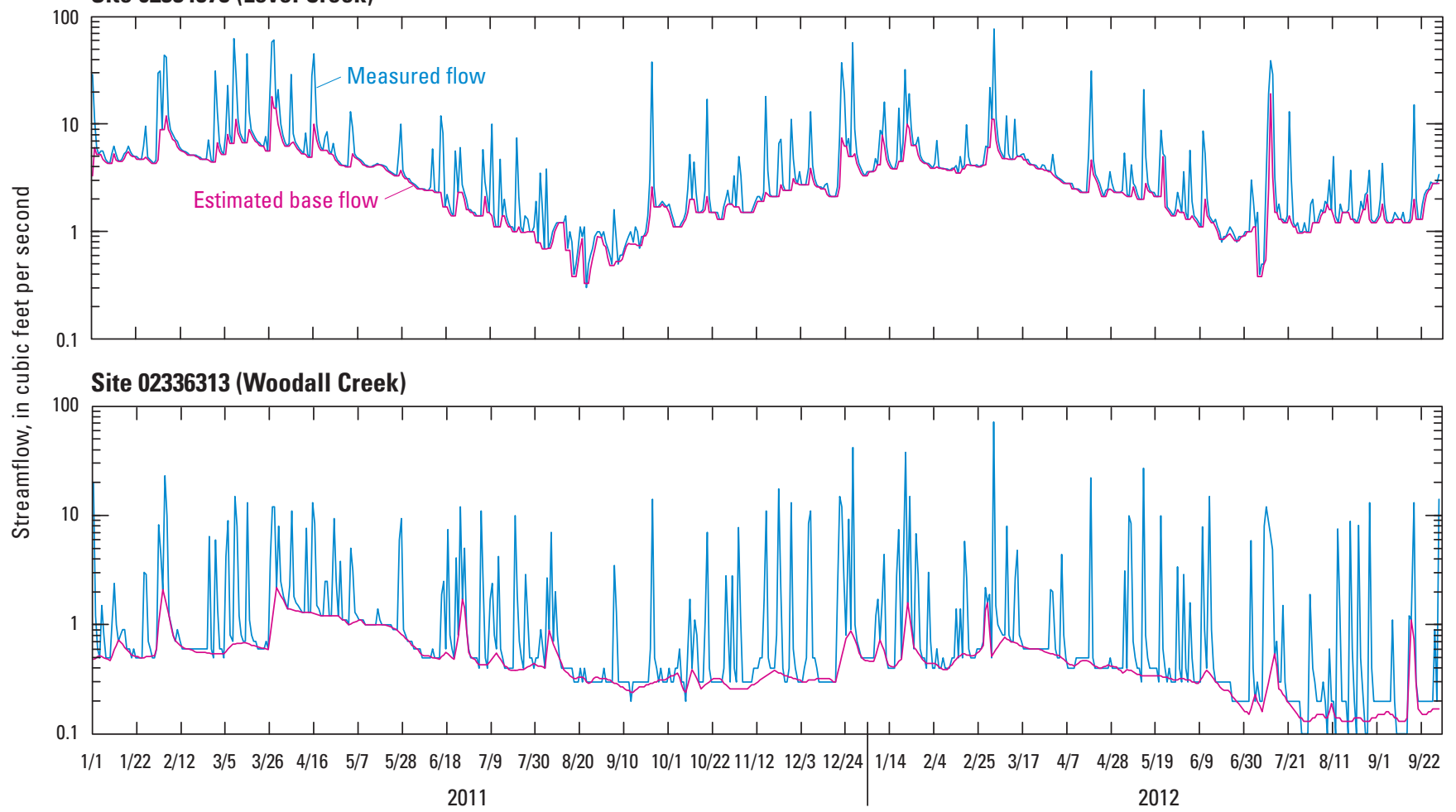

Figure 33. Base-flow separation using the local-minimum method for daily streamflow during January 2011 through September 2012 at USGS site 02334578 Level Creek at Suwannee Dam Creek near Suwannee, GA, and USGS site 02336313 Woodall Creek at Defoors Ferry Road, at Atlanta, GA (see fig. 1 for locations). 
Table 8. Summary of streamflow, estimated base flow, and base-flow yield during January 2011 through September 2012 at sites 02334578 (Level Creek) and 02336313 (Woodall Creek).

[p.10, 10th percentile; $p .25,25$ th percentile; . $.75,75$ th percentile; $p .90,90$ th percentile]

\begin{tabular}{|c|c|c|c|c|c|c|}
\hline \multirow{2}{*}{$\begin{array}{l}\text { Statistical } \\
\text { measure }\end{array}$} & \multicolumn{3}{|c|}{$\begin{array}{c}\text { Station: } 02336313 \text { Woodall Creek at Defoors Ferry Rd } \\
\text { at Atlanta GA }\end{array}$} & \multicolumn{3}{|c|}{$\begin{array}{c}\text { Station: } 02334578 \text { Level Creek at Suwanee Dam Road } \\
\text { near Suwanee GA }\end{array}$} \\
\hline & \multicolumn{2}{|c|}{ Cubic feet per second } & $\begin{array}{l}\text { Base-flow yield, } \\
\text { in cubic feet per } \\
\text { second per } \\
\text { square mile }\end{array}$ & \multicolumn{2}{|c|}{ Cubic feet per second } & $\begin{array}{l}\text { Base-flow yield } \\
\text { in cubic feet peI } \\
\text { second per } \\
\text { square mile }\end{array}$ \\
\hline Minimum & 0.1 & 0.13 & 0.05 & 0.3 & 0.33 & 0.07 \\
\hline p. 25 & 0.3 & 0.30 & 0.12 & 1.5 & 1.3 & 0.26 \\
\hline Median & 0.5 & 0.43 & 0.17 & 2.9 & 2.4 & 0.48 \\
\hline p.75 & 1.1 & 0.60 & 0.23 & 5.1 & 4.3 & 0.86 \\
\hline p. 90 & 4.92 & 1 & 0.38 & 8.72 & 4.3 & 0.86 \\
\hline Maximum & 72 & 2.2 & 0.85 & 77 & 19 & 3.8 \\
\hline
\end{tabular}

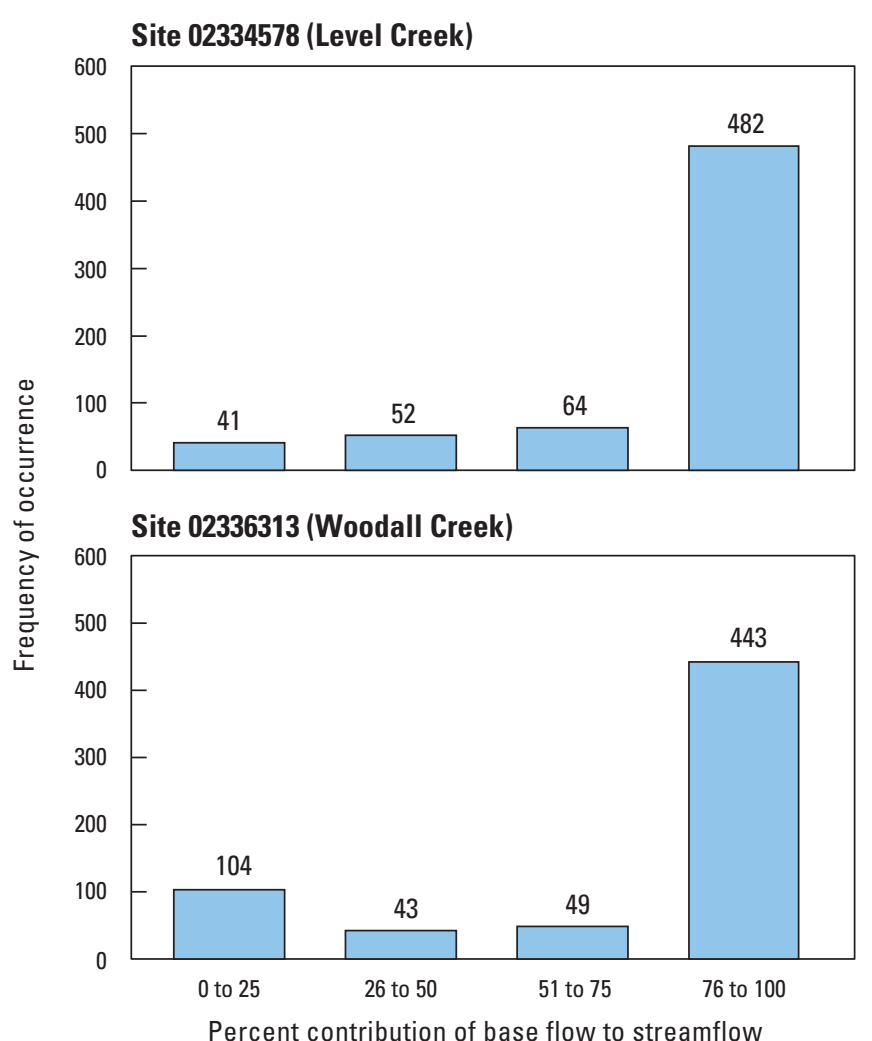

Figure 34. Percentage contribution of base flow to streamflow during January 2011 through September 2012 at USGS sites 02334578 (Level Creek) and 02336313 (Woodall Creek). 


\section{Influence of Septic System Percolation on Base Flow}

The influence of septic system percolation on base flow was assessed during the period leading up to and including the synoptic base-flow sampling (September 2-13, 2012) and for the January 2011-September 2012 period (figs. 35, 36). The graphs in figures 35 and 36 show base flow determined using hydrograph separation, and the estimated maximum septic system percolation rate.

Septic system percolation rates were estimated based on records of septic systems and household water use in each basin. These septic percolation estimates are the maximum possible contribution as it is likely that some portion of household water use is lost to evapotranspiration because of irrigation at the homesite or consumed as part of domestic household practices. As water flows from the septic absorption field through the riparian zone and into a stream, some of the water is probably lost to evapotranspiration during the growing season (fig. 11). Evapotranspiration is seasonally dependent and can be a large component of the water budget during the summer growing season. Because plants are still active during the month of September, it is likely that evapotranspiration diminished base flow in both basins during the September 2012 synoptic measurement period, as plants uptake groundwater within the basin that otherwise would have discharged into the stream.

During base-flow periods, streamflow consists primarily of groundwater inflow as it drains from the regolith and fractures in the bedrock. Groundwater inflow may be augmented by external components such as water main and sewer line leakage, irrigation, and septic system inflows, and diminished by pumping and PET. In addition to groundwater inflow, base flow may be influenced by unreported surfacewater discharges and unreported pumpage from groundwater and streams. Unreported surface-water discharges may include illicit discharges, swimming pool backwash, and car washing. Groundwater and surface-water pumping in the two study basins is considered negligible. Lawn irrigation may also contribute to base flow; however, this amount is also unknown.

Leakage from water and sewer mains can be a major contributor to streamflow, especially in urban areas where infrastructure is old; however, this is difficult to quantify. Landers and Ankcorn (2008) reported that water main leakage in Gwinnett County, Ga., was 3.5 percent of total finished water in 2007 according to George Kaffezakis (Gwinnett Department of Water Resources, written commun., January 2008). Lerner (2002) reported leakage rates of 20 to 25 percent are common for water mains.

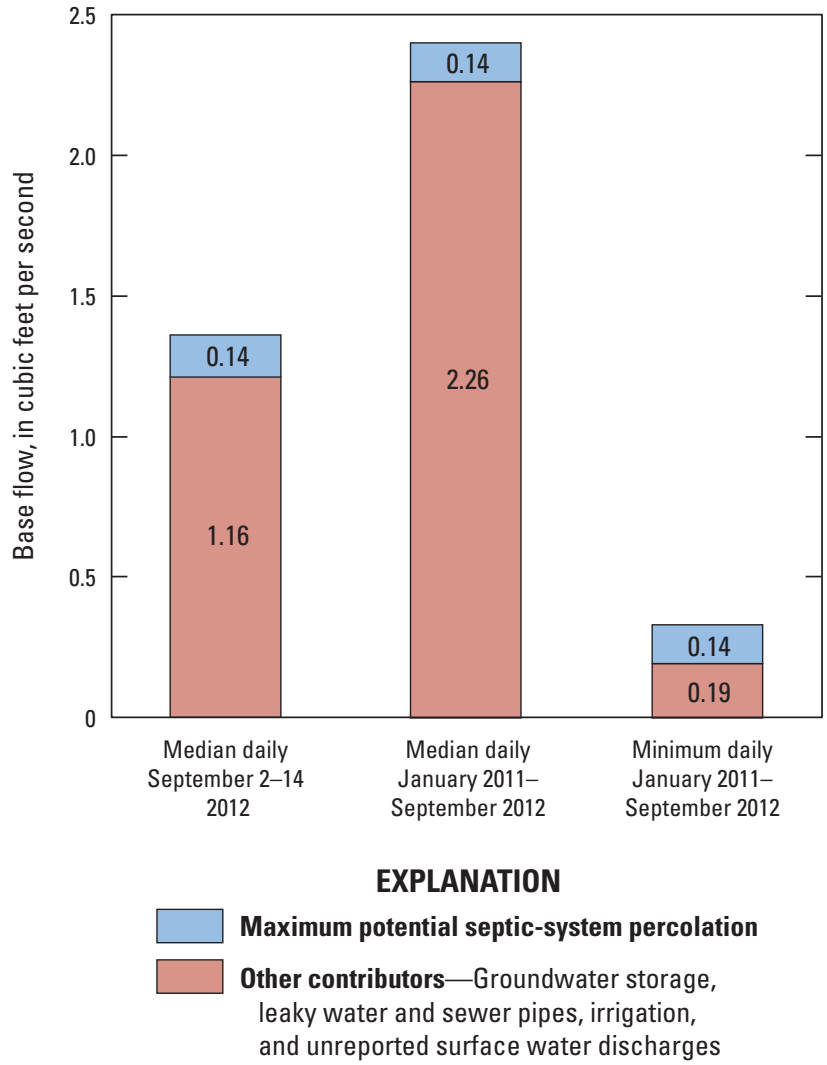

Figure 35. Base flow contributed by maximum potential septic system percolation and other contributors, USGS site 02334578 Level Creek at Suwannee Dam Creek near Suwannee, GA, January 2011-September 2012.

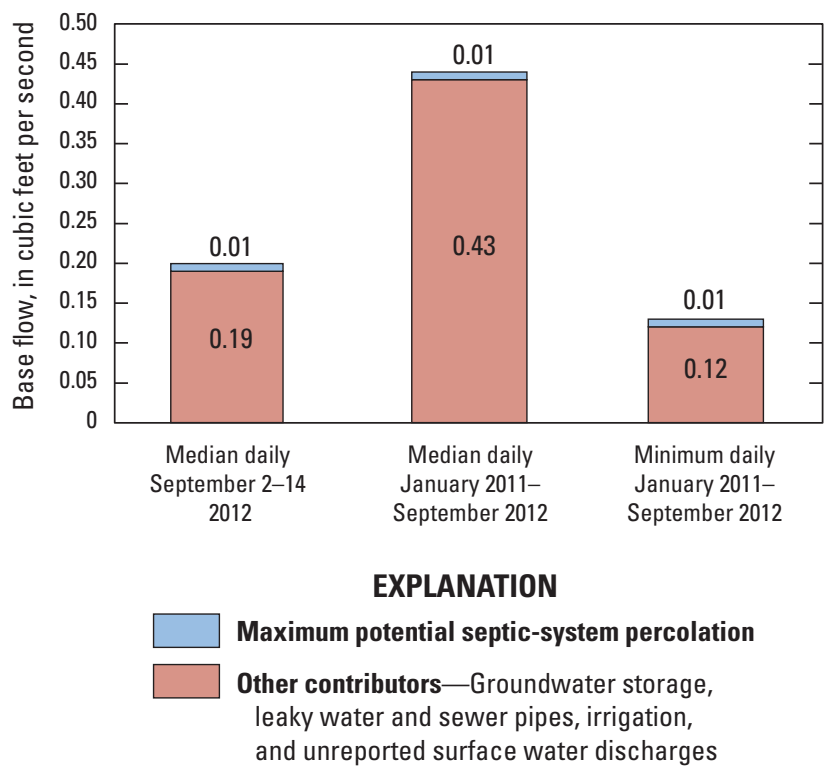

Figure 36. Base flow contributed by maximum potential septic system percolation and other contributors, USGS site 02336313 Woodall Creek at Defoors Ferry Road, at Atlanta, GA, January 2011-September 2012. 


\section{Level Creek Basin}

At Level Creek in Gwinnett County (02334578), there are 515 septic systems in the $5.08-\mathrm{mi}^{2}$ drainage area, for a septic system density of 101 systems/mi (figs. 30 and 31). Multiplying the number of sites by the average single family household use for 2009 for Gwinnett County of 173.5 gallons per day (gal/d; Metropolitan North Georgia Water Planning District, 2011) yields an average potential influx of septic system water of $89,368 \mathrm{gal} / \mathrm{d}$ or $0.14 \mathrm{ft}^{3} / \mathrm{s}$.

Figure 35 shows the amount of base flow at Level Creek potentially contributed by septic system percolation for (1) median daily base flow during September 2-14, 2012, and (2) for median and minimum daily base flow during January 2011-September 2012. The maximum amount of estimated septic system percolation that might contribute to base flow is $0.14 \mathrm{ft}^{3} / \mathrm{s}$, which is about 6 percent of median daily base flow during 2011-12. Maximum septic system percolation would contribute a considerably higher percentage during low-flow periods, providing about 11 percent of the base flow in September 2012, and 42 percent of minimum daily base flow measured during 2011-12. The balance of base flow is contributed by unknown sources. These percentages illustrate that detection of septic system contributions is more feasible during extreme low-flow periods; however, the low-flow volume results in less accurate flow measurements and may obscure the contribution. Since these numbers are maximum possible septic percolation, the actual contribution to flow is likely considerably smaller resulting in even greater difficulty in quantifying septic contribution to base flow.

\section{Woodall Creek Basin}

At Woodall Creek in the city of Atlanta, Fulton County (02336313), there are 50 septic systems in the $2.8-\mathrm{mi}^{2}$ drainage area, for a septic system density of 17.8 systems $/ \mathrm{mi}^{2}$ (figs. 30 and 32). Multiplying the number of sites by $125 \mathrm{gal} / \mathrm{d}$, the average single-family household use for 2009 in the Atlanta service area (Metropolitan North Georgia Water Planning District, 2011), yields a maximum potential influx of septic system water of $6,250 \mathrm{gal} / \mathrm{d}$ or $0.01 \mathrm{ft}^{3} / \mathrm{s}$.

The maximum potential septic system percolation rate for the LDS Woodall Creek Basin is $0.01 \mathrm{ft}^{3} / \mathrm{s}$, which is 14 times lower than in the HDS Level Creek Basin, accounting for only 2 percent of median daily base flow during 2011-12, 5 percent of the daily base flow during September 2-14, 2012, and 8 percent of the minimum daily base flow during 2011-12 (fig. 36). Since these numbers are maximum possible septic percolation, the actual contribution to flow is likely considerably smaller resulting in even greater difficulty in quantifying septic contribution to base flow.

\section{Maximum Potential Septic System Percolation Rate}

An estimate of the maximum potential contribution from septic systems in the study area was computed by determining the number of septic systems in a given county and multiplying this by the average single family household use for that county in 2009 as listed in table 9 (Metropolitan North Georgia Water Planning District, 2011). A map showing the estimated maximum percolation from septic systems is shown in figure 37. Potential septic system contribution was highest in areas of greatest density: Forsyth, southeastern Paulding, central Douglas, and south-central Hall Counties. Estimated maximum percolation from the 241,733 septic systems in the study area is $62 \mathrm{ft}^{3} / \mathrm{s}$ or $40 \mathrm{Mgal} / \mathrm{d}$, of which $52 \mathrm{ft}^{3} / \mathrm{s}$ (33.4 Mgal/d) is in the Chattahoochee River Basin and $10 \mathrm{ft}^{3} / \mathrm{s}$ $(6.5 \mathrm{Mgal} / \mathrm{d})$ is in the Flint River Basin.

Much of the residential water used in homes served by septic systems is unlikely to discharge to streams because some is lost to outdoor household use, evapotranspiration, and recharge to deep groundwater systems. An estimate of the potential contribution of septic system percolation to daily mean streamflow during January 2011 through September 2012 was made at the two farthest downstream streamgages in the study area - site 02338000 , Chattahoochee River near Whitesburg (drainage area 2,430 $\mathrm{mi}^{2}$ ), and site 02344350 , Flint River near Lovejoy (drainage area $130 \mathrm{mi}^{2}$, fig. 38). Daily mean streamflow at the two sites during water year 2012 was rated fair, with an associated accuracy of 15 percent.

At the Chattahoochee River site, daily mean streamflow ranged from 909 to $14,100 \mathrm{ft}^{3} / \mathrm{s}$ during this period, with a maximum potential septic system percolation throughout the basin of about 0.4 to 5.7 percent of daily median flow (fig. 38). Maximum potential septic system percolation represents such a small percentage of streamflow that it is unlikely it would be detected, given the approximately 15-percent uncertainty associated with daily streamflow measurements.

At the Flint River site, daily mean streamflow ranged from 5.6 to $1,900 \mathrm{ft}^{3} / \mathrm{s}$, with maximum potential septic system percolation throughout the basin ranging from 0.5 to 179 percent of the flow. The maximum potential septic percolation rate at the Flint River site exceeded 50 percent of daily mean streamflow several times during dry periods in August-November 2011, and May-September 2012 (fig. 38). Potential septic system percolation represents a large percentage of flow at the Flint River site, in part, because the drainage area and associated streamflow is lower than at the Chattahoochee River site. 


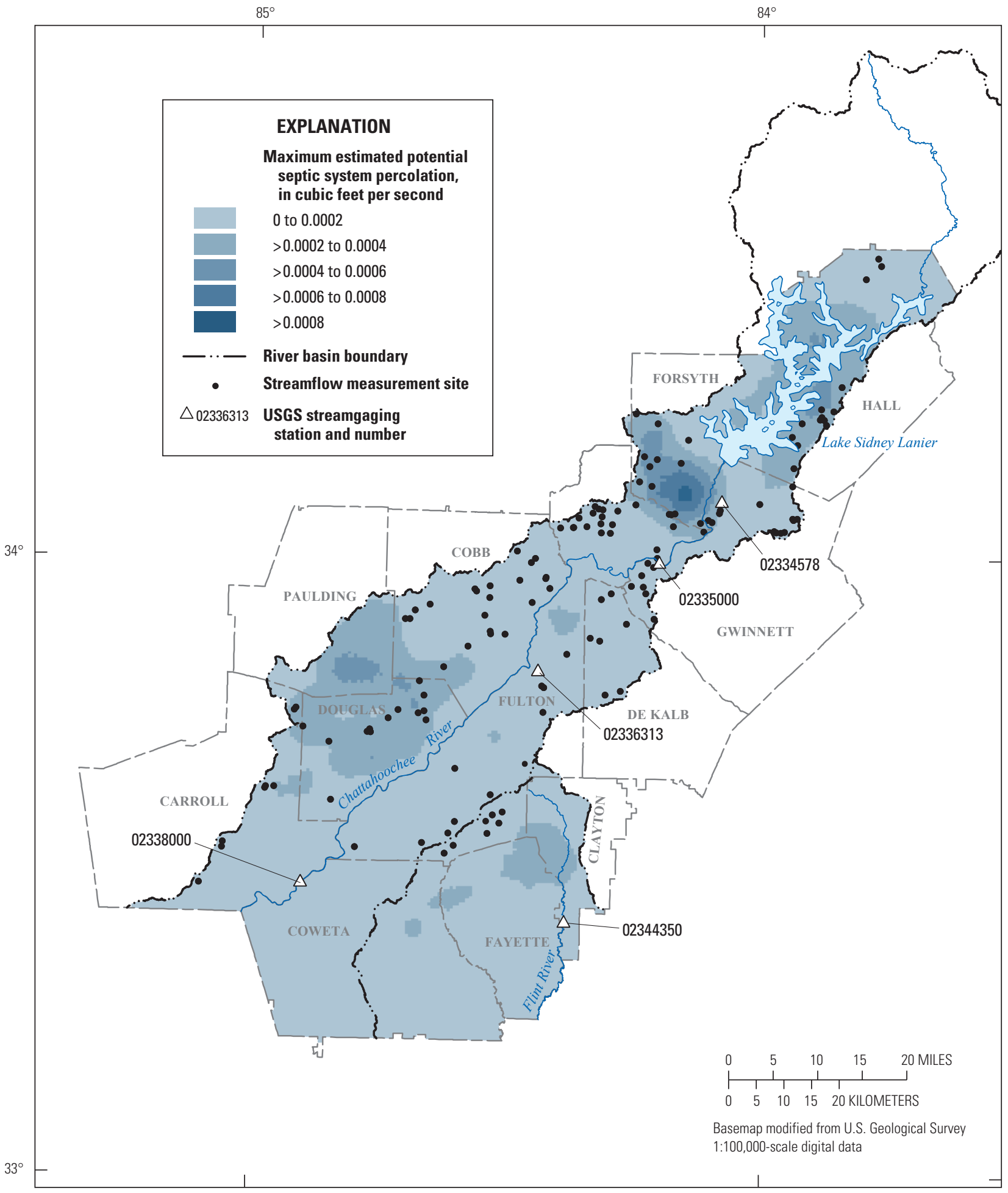

Figure 37. Maximum estimated potential septic system percolation rate in the study area. 
Site 02338000 (Chattahoochee River near Whitesburg)

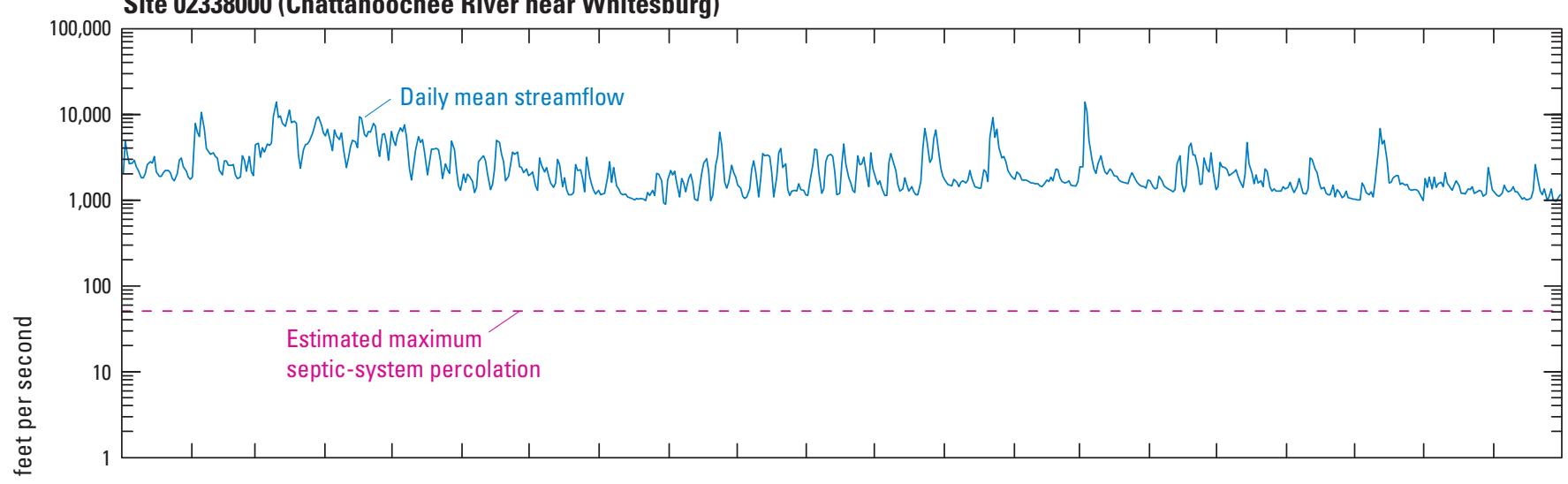

Site 02344350 (Flint River near Lovejoy)

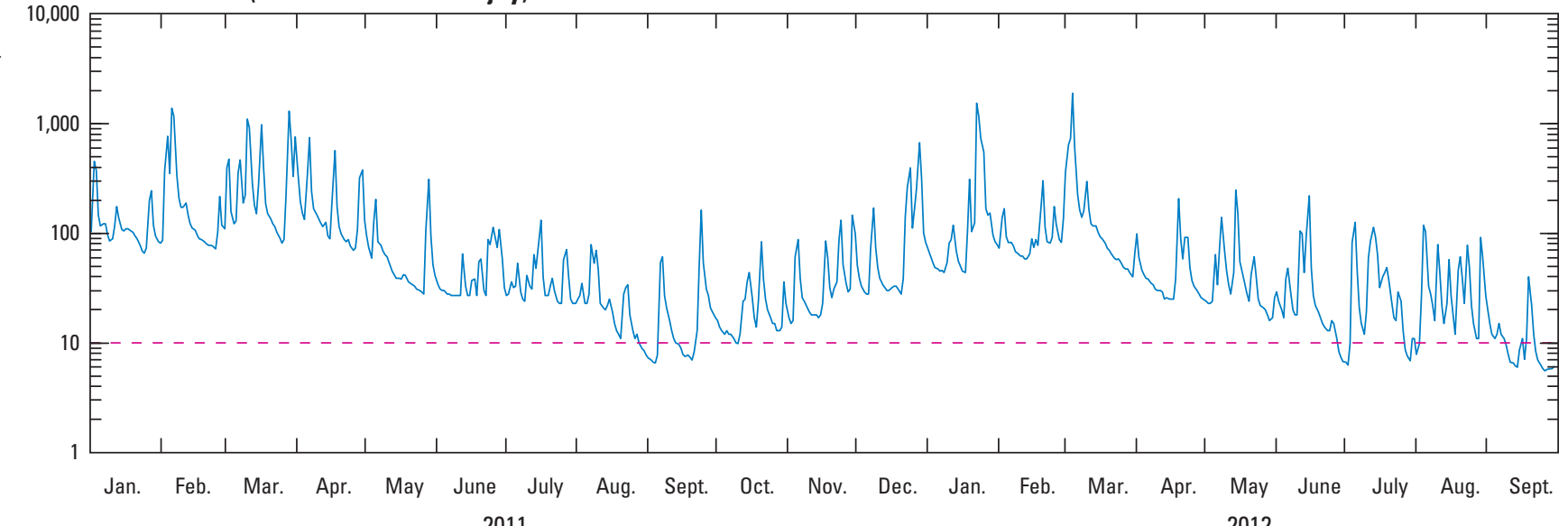

2011

2012

Figure 38. Daily mean streamflow at USGS site 02338000 Chattahoochee River near Whitesburg, GA, and USGS site 02344350 Flint River near Lovejoy, GA, and maximum potential contribution from septic system percolation, January 2011-September 2012 (see fig. 1 for locations).

Table 9. Average daily single family residential water use, 2009 (data from Metropolitan north Georgia Water Planning District, 2011). [-, not applicable]

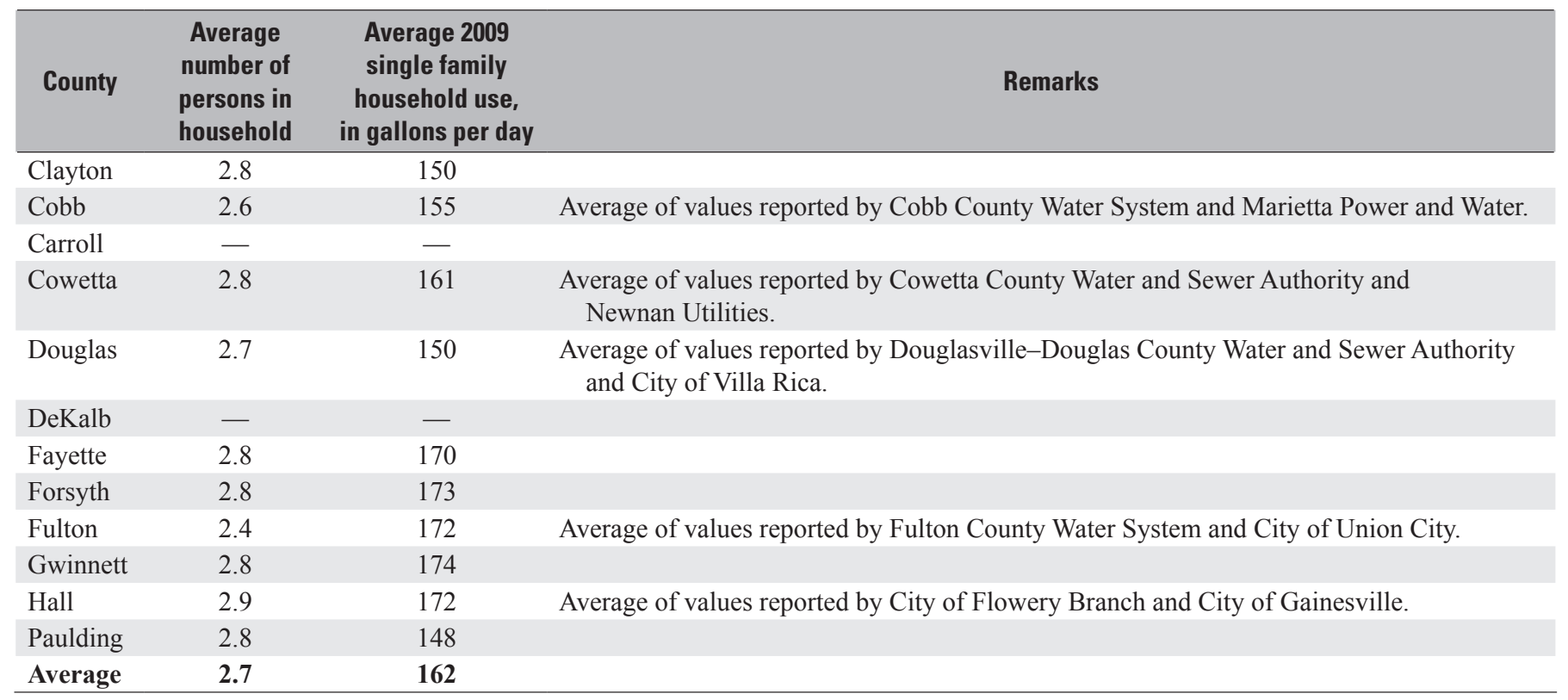




\section{Limitations of Analysis}

The assessment of the influence of septic system percolation on streamflow is limited by the accuracy of datasets and field measurements relative to the percent contribution to base flow by septic systems. Variations in rainfall patterns across the study area immediately prior to the synoptic measurement effort in September 2012 may have resulted in elevated base flow in parts of the area.

Elevation and slope are based on a 30-meter-resolution digital elevation model, so variations within smaller areas are not depicted. Soils data, including permeability, water table, bedrock depth, were derived from the Natural Resources Conservation Service State Soil Geographic (STATSGO) dataset (http://water.usgs.gov/GIS/metadata/usgswrd/XML/ ussoils.xml), a broad-based inventory of soils and non-soil areas shown at a scale of 1:250,000, designed for broad planning and management uses covering State, regional, and multistate areas. Variations at smaller scales may not be captured by this analysis.

The geology of the Piedmont physiographic province is considerably more complex than the delineation of geologic areas used in this report. Local variations in rock type and geologic structure that may affect groundwater flow and stream base flow are not captured by the coarse resolution data used in this study.

The method to delineate locations of septic systems was based largely on an analysis of billing records and locating septic systems at the center of land parcels by geocoding addresses. On large land parcels, the location of septic systems at the center of the property may put a septic system into the wrong basin and result in differences in the analysis.

Because many of the streamflow measurements were made in extremely low-flow conditions, the margin of error is wide, within many measurements having errors greater than 10 percent (appendix 1). These errors may obscure detection of differences in base flow between basins attributed to septic system recharge, as illustrated in the Level Creek and Woodall Creek Basins. Using the 10-percent measurement accuracy reported for daily mean discharge at Level Creek (02334578, appendix 1), the margin of error for (1) the 2011-12 median discharge would be $0.24 \mathrm{ft}^{3} / \mathrm{s}$; (2) the 2011-12 minimum discharge would be $0.04 \mathrm{ft}^{3} / \mathrm{s}$, and; (3) the discharge measured during the measurement period in September 2012 would be $0.12 \mathrm{ft}^{3} / \mathrm{s}$. The maximum potential septic system percolation rate for the Level Creek Basin is $0.14 \mathrm{ft}^{3} / \mathrm{s}$. Thus, detection of differences in base flow attributed to septic system percolation could be obscured by measurement errors for median conditions during $2011-12$ because its magnitude $\left(0.14 \mathrm{ft}^{3} / \mathrm{s}\right)$ is lower than the measurement error $\left(0.24 \mathrm{ft}^{3} / \mathrm{s}\right)$. During the September 2012 measurement period, the contribution of septic systems to base flow would be unlikely to be detected, as the maximum potential septic system percolation rate of
$0.14 \mathrm{ft}^{3} / \mathrm{s}$ is only slightly larger than the error in base-flow measurements of $0.12 \mathrm{ft}^{3} / \mathrm{s}$.

Assuming a measurement accuracy of 10 percent at Woodall Creek, the margin of error for (1) the 2011-12 median would be $0.04 \mathrm{ft}^{3} / \mathrm{s}$; (2) the 2011-12 minimum would be $0.01 \mathrm{ft}^{3} / \mathrm{s}$, and; (3) the September 2012 would be $0.02 \mathrm{ft}^{3} / \mathrm{s}$. The maximum potential septic system percolation rate for the Woodall Creek Basin is $0.01 \mathrm{ft}^{3} / \mathrm{s}$. Thus, detection of differences in base flow attributed to septic system percolation could be obscured by measurement errors for all three conditions because its magnitude $\left(0.01 \mathrm{ft}^{3} / \mathrm{s}\right)$ is lower than the measurement error ( 0.01 to $\left.0.04 \mathrm{ft}^{3} / \mathrm{s}\right)$.

Comparison of base flow between HDS and LDS basins was complicated by a variety of other factors that may obscure any gains in base flow attributed to septic system percolation. This includes increased groundwater recharge caused by leaky water or sewer mains and high rates of evapotranspiration during the synoptic period in September 2012. Completing a synoptic measurement effort during a dry period later in the year during the dormant season, when evapotranspiration effects are diminished, may produce a more pronounced difference in base flow between HDS and LDS basins. Collection of water samples for analysis of nitrates and bacteria would also provide some confirmation of the contribution of base flow from septic system percolation.

\section{Summary and Conclusions}

Septic system percolation may locally be an important component of streamflow in small drainage basins where it augments natural groundwater recharge, especially during extreme low-flow conditions. The amount of groundwater reaching streams depends on how much is intercepted by plants or infiltrates to deeper parts of the groundwater system that flows beyond a basin divide and does not discharge into streams within a basin. Evapotranspiration varies seasonally and is greatest during the growing season. In addition to septic systems, leaking water mains and sanitary sewers, stormwater drains, and runoff diversion and storage structures can contribute to enhanced groundwater recharge and base flow.

Septic systems were identified at 241,733 sites in a 2,539-square-mile $\left(\mathrm{mi}^{2}\right)$ study area that includes all or parts of 12 counties in the Metropolitan Atlanta area. The highest density of septic systems was in the southern part of Forsyth County, where the density exceeds 350 systems per square mile (systems $/ \mathrm{mi}^{2}$ ). Other counties having high density of systems (HDS) include southeastern Paulding, central Douglas, and south-central Hall Counties, where density exceeds 250 systems $/ \mathrm{mi}^{2}$.

The potential maximum percolation from septic systems in the study area is 62 cubic feet per second $\left(\mathrm{ft}^{3} / \mathrm{s}\right)$ 
or 40 million gallons per day (Mgal/d), of which $52 \mathrm{ft}^{3} / \mathrm{s}$ (33.4 Mgal/d) is in the Chattahoochee River Basin and $10 \mathrm{ft}^{3} / \mathrm{s}$ (6.5 Mgal/d) is in the Flint River Basin. These maximum percolation rates represent 0.4 to 5.7 percent of daily mean streamflow during the 2011-12 period at the farthest downstream gaging site (02338000) on the Chattahoochee River, and 0.5 to 179 percent of daily mean streamflow at farthest downstream gaging site on the Flint River (02344350).

Maximum septic system percolation represents such a small percentage of streamflow at the Chattahoochee River site that it is unlikely it would be detected, given that the uncertainty of most of the discharge measurements is greater than 10 percent. Maximum septic system percolation represents a larger percentage of streamflow at the Flint River site because this site has a nearly 19-times smaller drainage area than at the Chattahoochee River site. Septic system contribution is, therefore, more likely to be detected within the measurement accuracy of streamflow.

To determine the difference in base flow between basins having different septic system densities, hydrograph separation analysis was completed using daily mean streamflow data at Level Creek (station number 02334578), with a relatively high septic system density of $101 \mathrm{systems} / \mathrm{mi}^{2}$, and Woodall Creek (station number 02336313), with a relatively low septic system density of 18 systems $/ \mathrm{mi}^{2}$. Results indicated that base-flow yield during 2011-12 was higher at Level Creek, with a median of 0.47 cubic feet per second per square mile $\left(\left[\mathrm{ft}^{3} / \mathrm{s}\right] / \mathrm{mi}^{2}\right)$, compared to a median of $0.16\left(\mathrm{ft}^{3} / \mathrm{s}\right) / \mathrm{mi}^{2}$ at Woodall Creek. Septic system percolation contributed only a minor portion of total base flow, with the balance contributed by unknown contributions from external components such as water main and sewer line leakage, irrigation, and unreported surface-water discharges. At the less urbanized Level Creek site, there are 515 septic systems with a daily maximum percolation rate of $0.14 \mathrm{ft}^{3} / \mathrm{s}$, accounting for 11 percent of the base flow in September 2012. At the more urban Woodall Creek site, there are 50 septic systems with an average daily maximum percolation rate of $0.0097 \mathrm{ft}^{3} / \mathrm{s}$, accounting for 5 percent of base flow in September 2012.

Streamflow measurements at 133 small drainage basins (less than $5 \mathrm{mi}^{2}$ in area) during September 2012, indicated no statistically significant difference in flow or specific conductance between basins having high and low density of septic systems (HDS and LDS). The median base-flow yield for HDS sites was $0.04\left(\mathrm{ft}^{3} / \mathrm{s}\right) / \mathrm{mi}^{2}$ of drainage area ranging from 0 to $0.52\left(\mathrm{ft}^{3} / \mathrm{s}\right) / \mathrm{mi}^{2}$ and for LDS sites was $0.10\left(\mathrm{ft}^{3} / \mathrm{s}\right) / \mathrm{mi}^{2}$ ranging from 0 to $0.49\left(\mathrm{ft}^{3} / \mathrm{s}\right) / \mathrm{mi}^{2}$. A Wilcoxon rank-sum test indicated the median base-flow yields for HDS and LDS sites were not statistically different, with a p-value of 0.345 . The mean specific conductance for HDS sites was 83.39 microsiemens per centimeter at 25 degrees Celsius $(\mu \mathrm{S} / \mathrm{cm})$ ranging from 13 to $183 \mu \mathrm{S} / \mathrm{cm}$, and for LDS sites the mean value was $126.46 \mu \mathrm{S} / \mathrm{cm}$, ranging from 29 to $675 \mu \mathrm{S} / \mathrm{cm}$. A Wilcoxon rank-sum test run on median values of specific conductance from HDS and LDS sites indicated that differences in median values were insignificant ( $p$-value 0.082 ).

Because of the large size of the study area and associated variations in basin characteristics, data collected in September 2012 were also evaluated using a number of groupings in an attempt to reduce or eliminate other basin characteristics that might affect base flow. Within each grouping, data were subdivided into HDS and LDS basins; the three groupings used are geologic area, four geographic subareas, and 45-meter buffer zone. Regardless of grouping, there was no statistically significant difference between median base-flow yield for HDS and LDS basins. Detection of the septic percolation component of base flow was likely obscured by the uncertainty of streamflow measurements, which may exceed the amount of flow contributed by septic system percolation. In addition, because the measurement effort was completed during a period of active evapotranspiration, much of the septic percolation may have been intercepted prior to discharging into a stream. Detection of septic system percolation in HDS basins may also have been complicated by leaky water and sewer mains, which may have resulted in higher streamflows in LDS basins relative to HDS basins.

The lack of a statistically significant difference in mean base-flow yield or specific conductance for HDS and LDS sites differs from a previous study, which reported base-flow yield was 90 percent greater in HDS than in LDS watersheds and that specific conductance of base flow was generally higher in the HDS watersheds than in the LDS basins in Gwinnett County, Ga. Compared to the present study, the previous Gwinnett County study was completed in a considerably smaller study area during a period of extreme drought; thus, site conditions were more uniform over the study area and variations attributed to septic system percolation were more readily detected. In addition, the LDS sites in the previous study were more rural and not on sewer systems, thus minimizing the possibility that contributions from leaking sanitary sewers or water mains interfere with detecting septic system percolation.

It is likely that the contribution from septic system percolation at many of the sites visited in September 2012 was obscured by a combination of measurement error and evapotranspiration. Future synoptic measurement efforts would have a better chance of identifying variations attributed to septic system percolation if they were conducted later in the year when evapotranspiration effects are diminished. Stream-water samples analyzed for nitrate, bacteria, or other sewage tracers would provide an independent indicator of septic system percolation. Additional streamgages in small drainage basins in HDS and LDS areas would enable further analysis using hydrograph separation techniques to provide a more complete seasonal evaluation of the relative contributions attributed to septic system percolation. 


\section{Selected References}

Atlanta Regional Commission, 2009, LandPro land use dataset: Accessed on April 22, 2014, at http://www. atlantaregional.com/info-center/gis-data-maps.

Bartolino, J.R., 2009, Ground-water budgets for the Wood River Valley aquifer system, south-central Idaho, 1995-2004: U.S. Geological Survey Scientific Investigations Report 2009-5016, 36 p. (Also available at http://pubs.usgs.gov/sir/2009/5016/sir20095016.pdf.)

Clark, W.Z., Jr., and Zisa, A.C., 1976, Physiographic map of Georgia: Georgia Geologic Survey, scale 1:2,000,000.

Copeland, C.W., 1968, Geology of the Alabama Coastal Plain: Geological Survey of Alabama Circular 47, 97 p.

Draper, S.L., 2005, Sharing water through interbasin transfer and basin of origin protection in Georgia-Issues for evaluation in comprehensive state water planning for Georgia's surface water rivers and groundwater aquifers: Georgia State University Law Review, v. 21, no. 2, p. 339-372.

Drought Mitigation Center, 2013, Drought monitor archives: Accessed September 26, 2013, at http://droughtmonitor.unl. edu/MapsAndData/MapArchive.aspx.

Fanning, J.L., 2007, Consumptive water use-A critical component of Georgia's comprehensive statewide watermanagement plan, in Proceedings of the 2007 Georgia Water Resources Conference, March 27-29, 2007: Athens, Georgia, The University of Georgia. (Also available at http://www.gwri.gatech.edu/sites/default/files/files/ docs $/ 2007 / 8.23 . p d f$.)

Georgia Automated Environmental Monitoring Network, 2013, Georgia Automated Environmental Monitoring Network homepage: Accessed June 24, 2013 at http://www.griffin.uga.edu/aemn/.

Georgia Division of Public Health, 2007, Manual for on-site sewage management systems: Georgia Department of Human Resources, 277 p. (Also available at http://dph.georgia.gov/sites/dph.georgia.gov/files/ related_files/site_page/EnvHealthOnsiteManual.pdf.)

Hutson, S.S., Barber, N.L., Kenny, J.F., Linsey, K.S., Lumia, D.S., and Maupin, M.A., 2004, Estimated use of water in the United States in 2000: U.S. Geological Survey Circular 1268, 46 p.
Hsieh, P.A., Barber, M.E., Contor, B.A., Hossain, M.A., Johnson, G.S., Jones, J.L., and Wylie, A.H., 2007, Groundwater flow model for the Spokane Valley-Rathdrum Prairie aquifer, Spokane County, Washington, and Bonner and Kootenai Counties, Idaho: U.S. Geological Survey Scientific Investigations Report 2007-5044, 79 p. (Also available at http://pubs.usgs.gov/sir/2007/5044/.)

LaFontaine, Jacob, 2009, Hydrologic characteristics of watersheds in Metropolitan Atlanta, Georgia, 2003-2006: in Proceedings of the 2009 Georgia Water Resources Conferences, April 27-29, 2009: Athens, Georgia: The University of Georgia, p. 235.

Landers, M.N., and Ankcorn, P.D., 2008, Methods to evaluate influence of onsite septic wastewater-treatment systems on base flow in selected watersheds in Gwinnett County, Georgia, October 2007: U.S. Geological Survey Scientific Investigations Report 2008-5220, 12 p. (Also available at http://pubs.usgs.gov/sir/2008/5220/.)

Landers, M.N., and Painter, J.A., How much water is in the Apalachicola, Chattahoochee, and Flint Rivers, and how much is used?: U.S. Geological Survey Fact Sheet 2007-3034, 4 p.

Leitman, H.M., Sohm, I.E., and Franklin, M.A., 1983, Wetland hydrology and tree distribution of the Apalachicola River flood plain, Florida: U.S. Geological Survey Water-Supply Paper 2196, $52 \mathrm{p}$.

Lerner, D.N., 2002, Identifying and quantifying urban recharge-A review: Hydrogeology Journal, v. 10, p. $143-152$.

Marella, R.J., Fanning, J.L., and Mooty, W.S., 1993, Estimated use of water in the Apalachicola-Chattahoochee-Flint River Basin during 1990 with State summaries from 1970 to 1990: U.S. Geological Survey Water Resources Investigations Report 93-4084, 45 p.

Metropolitan North Georgia Water Planning District, 2006, Septic systems status and issues working paper: Atlanta, Georgia, 37 p., accessed December 11, 2013, at http://documents.northgeorgiawater.org/District_Septic_ Report_Mar2006.pdf.

Metropolitan North Georgia Water Planning District, 2011, Water metrics report, February 2011: Prepared by the Atlanta Regional Commission, 55 p., accessed April 22, 2014, at http://documents.northgeorgiawater. org/2010_Water_Metrics_Report_FINAL\%281\%29.pdf. 
Metropolitan North Georgia Water Planning District, 2013, Metropolitan North Georgia Water Planning District homepage: Accessed June 10, 2013, at http://www.northgeorgiawater.com/.

McConnell, K.I., and Abrams, C.F., 1984, Geology of the greater Atlanta region: Georgia Geologic Survey Bulletin 96: $127 \mathrm{p}$.

Multi-Resolution Land Characteristics Consortium, 2006, National Land Cover Dataset, accessed April 22, 2014, at http://www.mrlc.gov/nlcd06_data.php.

Paul, W.T., 2007, Water budget of mountain residence, Jefferson County, Colorado: Colorado School of Mines, M.S. thesis, $68 \mathrm{p}$.

Priest, Sherlyn, 2004, Stream-aquifer relations in the coastal area of Georgia and adjacent parts of Florida and South Carolina: Georgia Geologic Survey Information Circular 108, $40 \mathrm{p}$.

Rantz, S.E., 1982, Measurement and computation of streamflow-Measurement of stage and discharge: U.S. Geological Survey Water-Supply Paper 1.0.

Sloto, R.A., and Crouse, M.Y., 1996, HYSEP: A computer program for streamflow hydrograph separation and analysis: U.S. Geological Survey Water-Resources Investigations Report 96-4040, 67 p.

Stewart, W.B, and Rouse, W.R., 1976, A simple method for determining the evaporation from shallow lakes and ponds: Water Resources Research, v. 12, no. 4, p. 623-628.
U.S. Geological Survey, 1999, The National Hydrography Dataset: U.S. Geological Survey Fact Sheet 106-99, 2 p., accessed June 24, 2014, at http://pubs.er.usgs.gov/ publication/fs 10699 .

U.S. Geological Survey, 2009, The National Map-Elevation: U.S. Geological Survey Fact Sheet 2009-3053, 4 p., accessed July 24, 2012, at http://pubs.usgs.gov/fs/2009/3053/.

U.S. Department of Housing and Urban Development and U.S. Census Bureau, 2005, American housing survey for the Atlanta metropolitan area: 2004-Current housing reports: Series H170/04-21, 356 p., accessed January 2008, at http:www.census.gov/prod/2005pubs/h170-04-21.pdf.

U.S. Environmental Protection Agency, 2002, Onsite wastewater-treatment systems manual: National Risk Management Research Laboratory Report EPA/625/R-00/008, 215 p.

U.S. Army Corps of Engineers, 2004, Extended unimpaired flow report, January 1994-December 2001, for the ACT/ ACF River Basins: $34 \mathrm{p}$.

Wahl, K.L., and Wahl, T.L., 1995, Determining the flow of Comal Springs at New Braunfels, Texas, in Proceedings of Texas Water '95, August 16-17, 1995, San Antonio, Texas: American Society of Civil Engineers, p. 77-86.

Yang, Y., Learner, D.N., Barrett, M.H., and Tellam, J.H., 1999, Quantification of groundwater recharge in the city of Nottingham, UK: Environmental Geology, v. 38, p. 183-198. 

Appendixes 


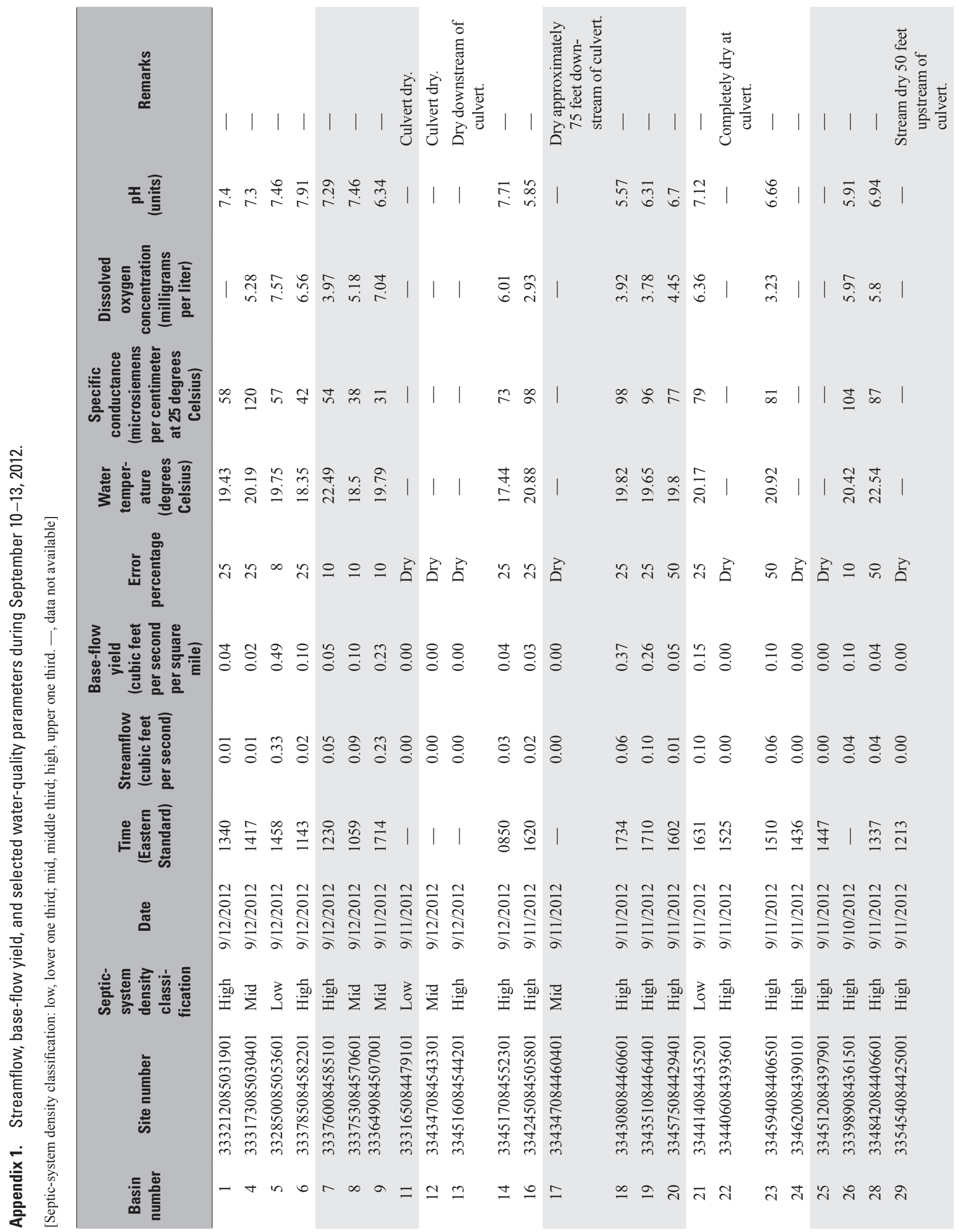




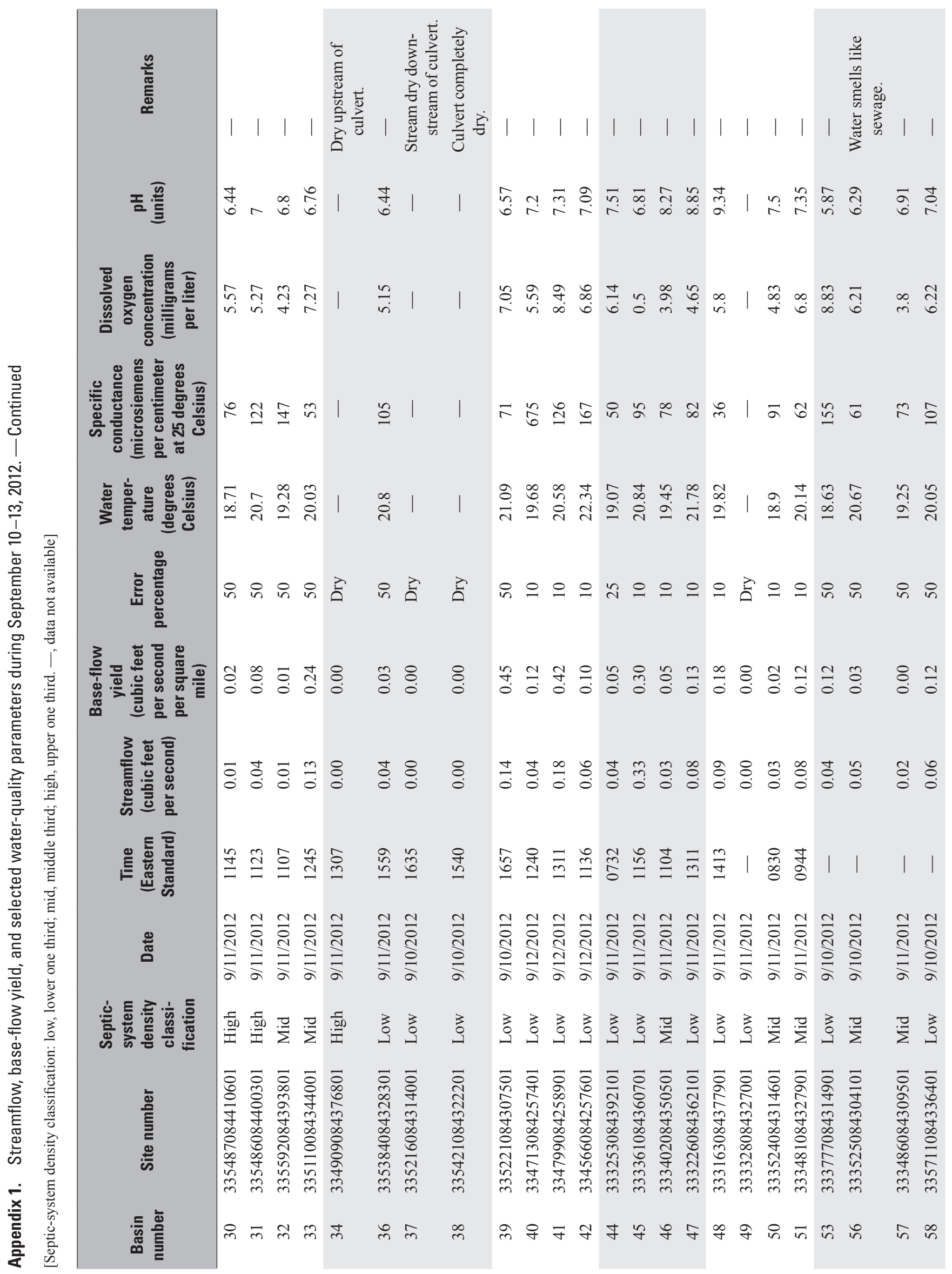




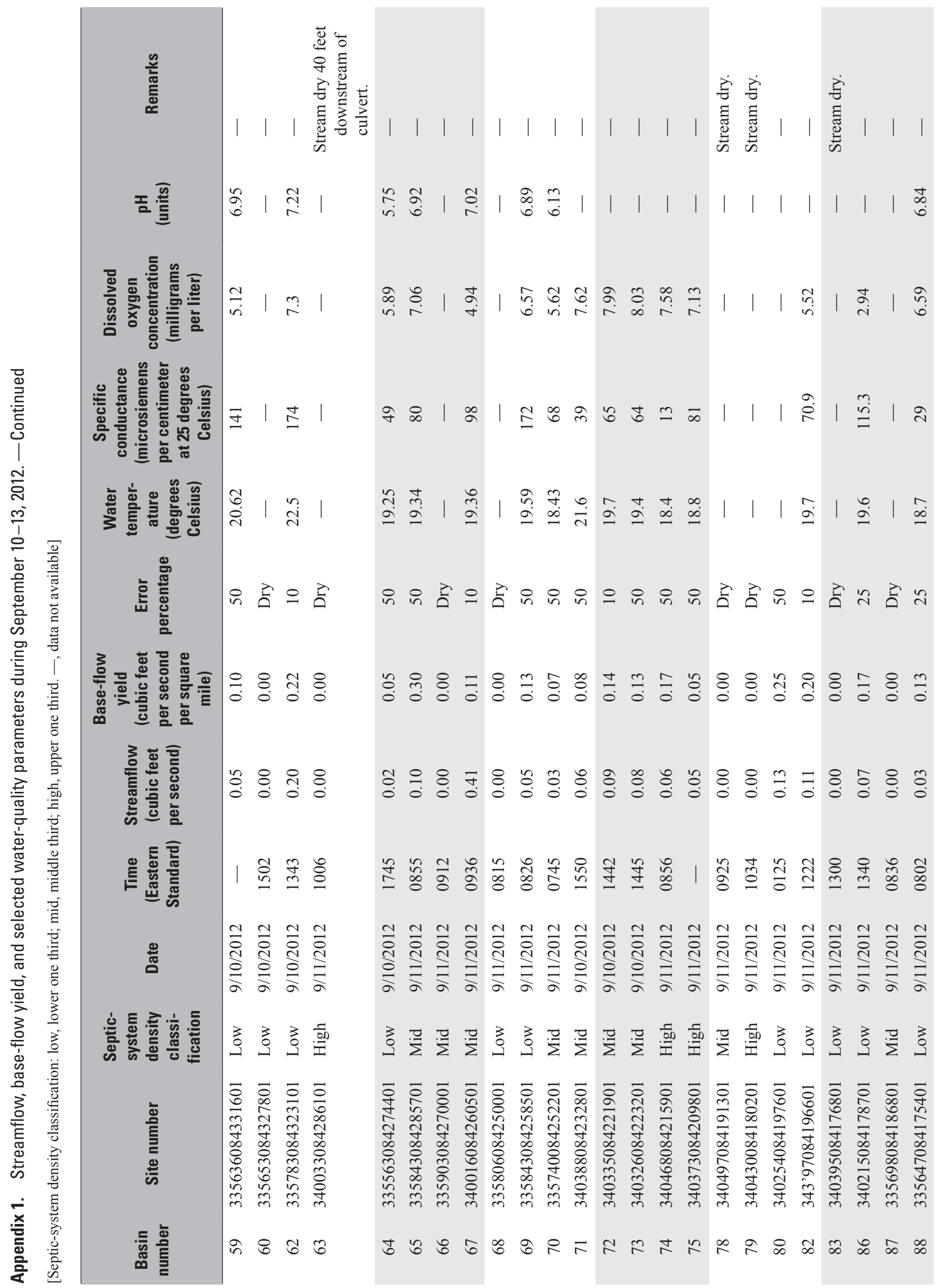




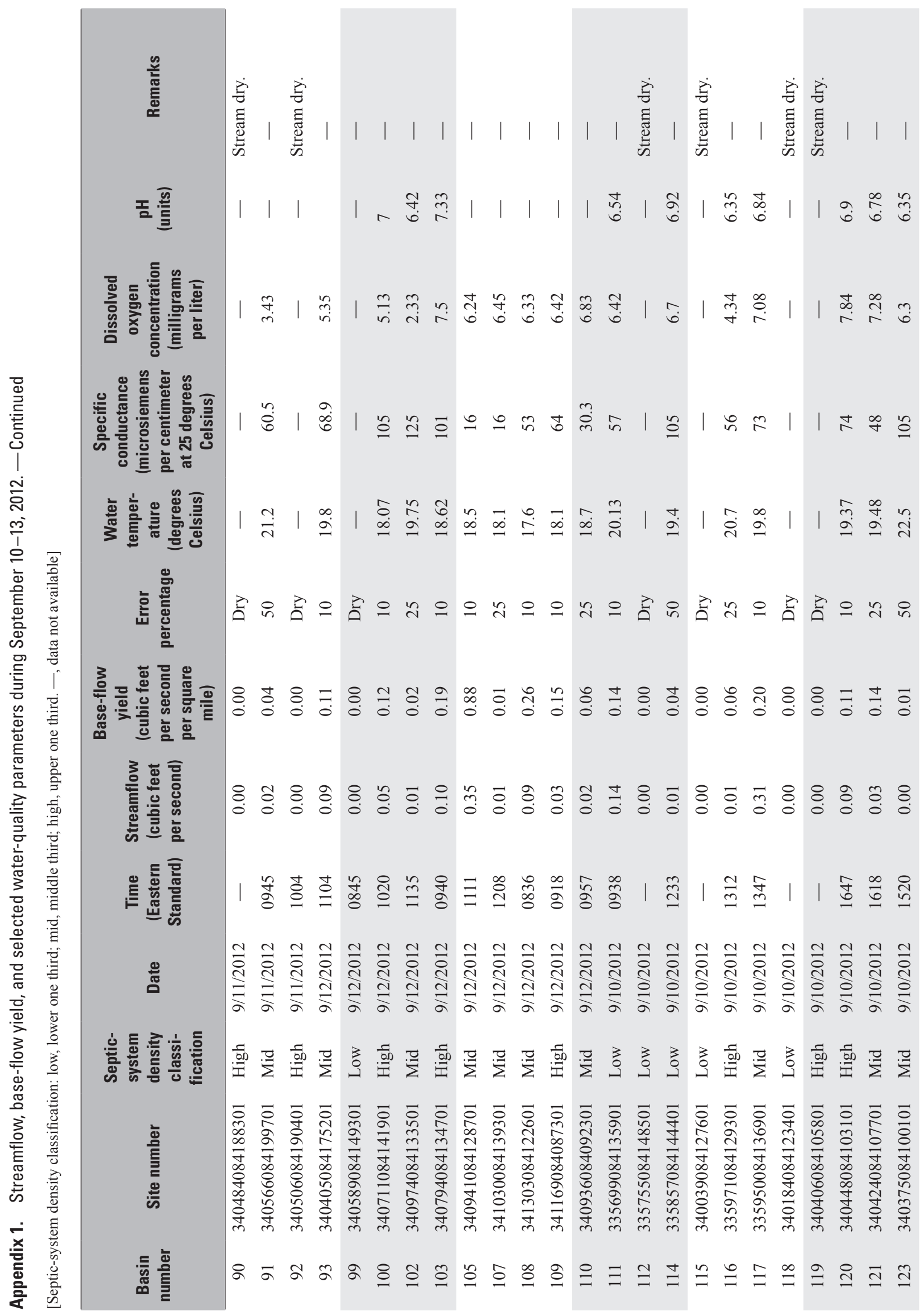




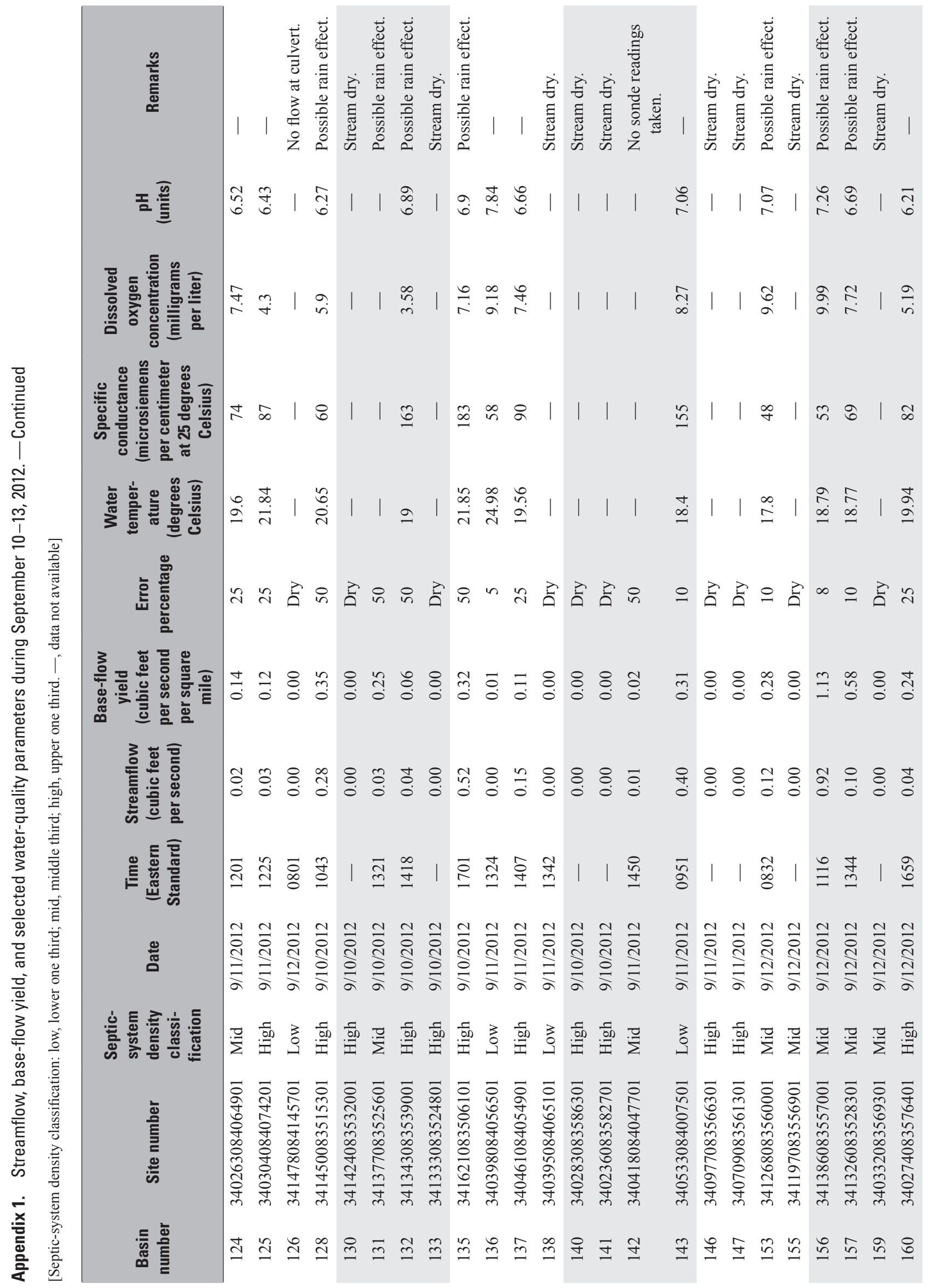




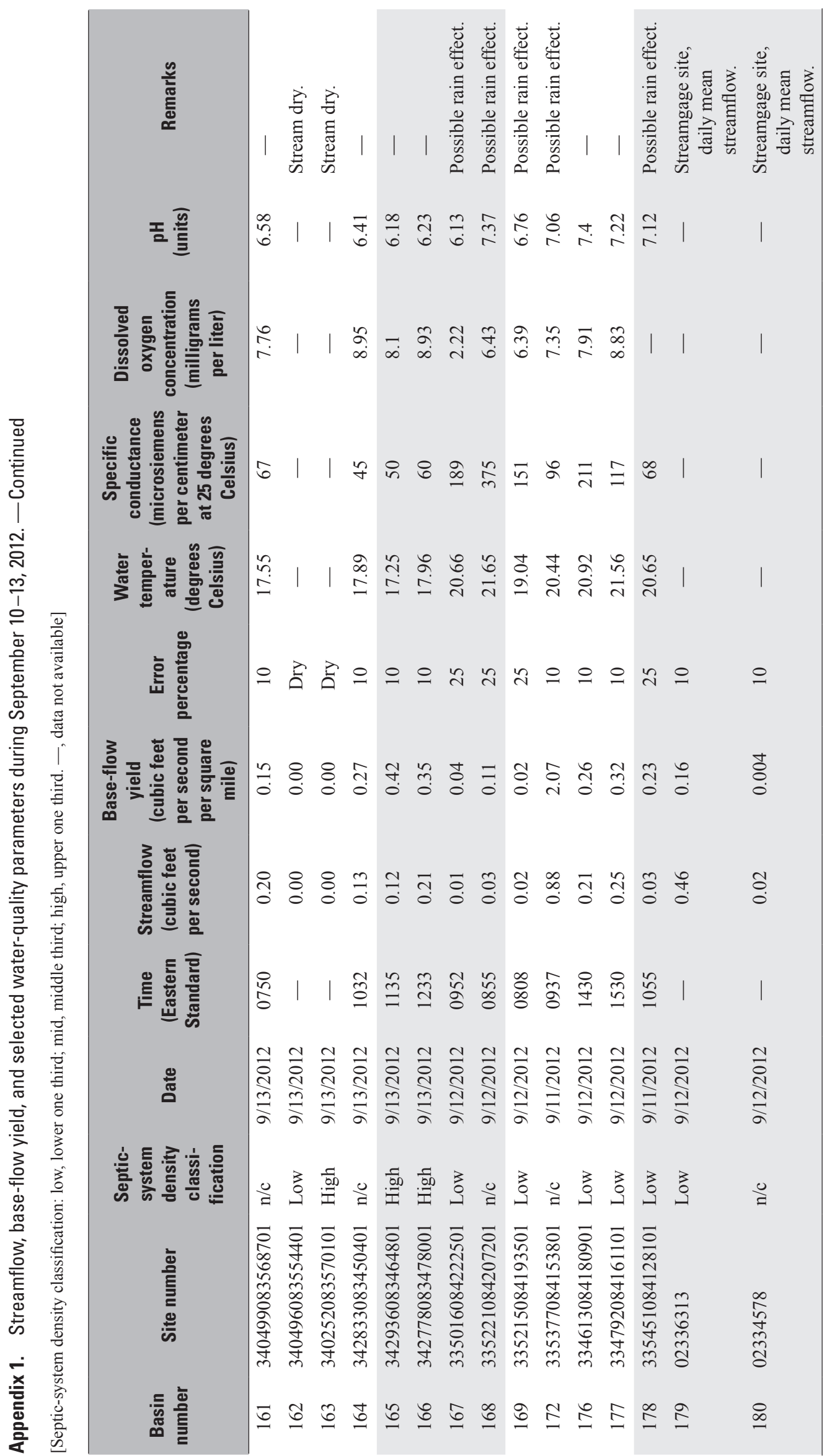




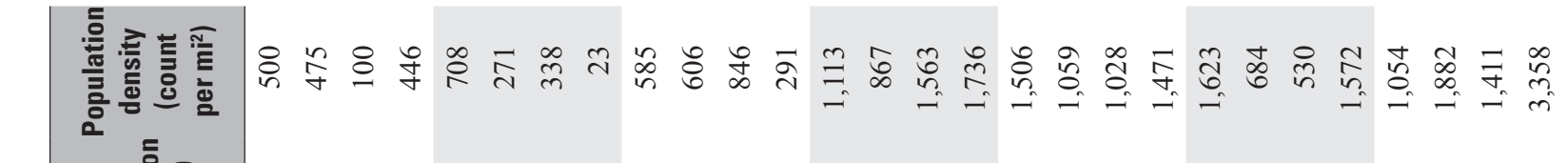
茪

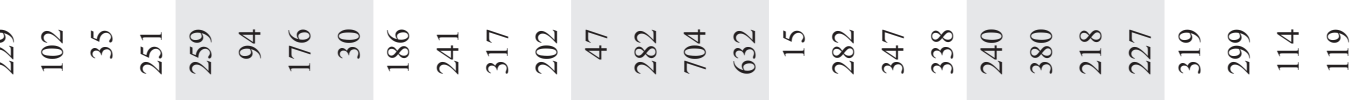

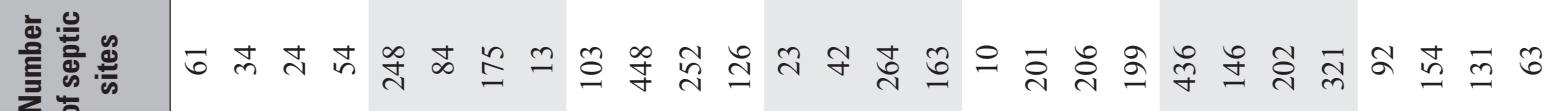
里 


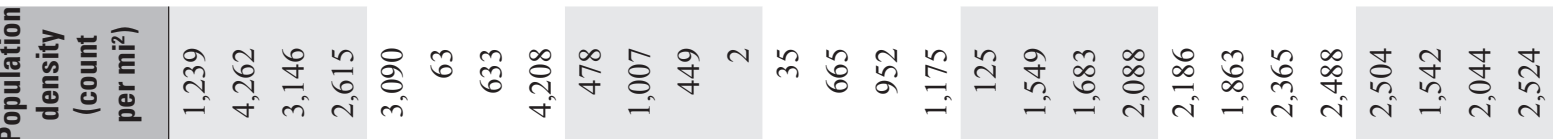

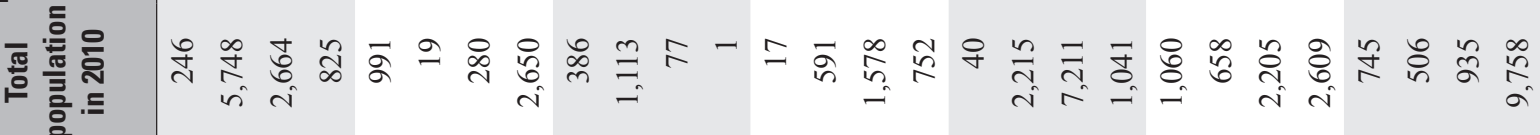

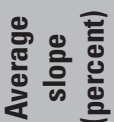

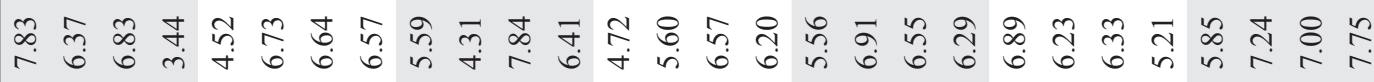

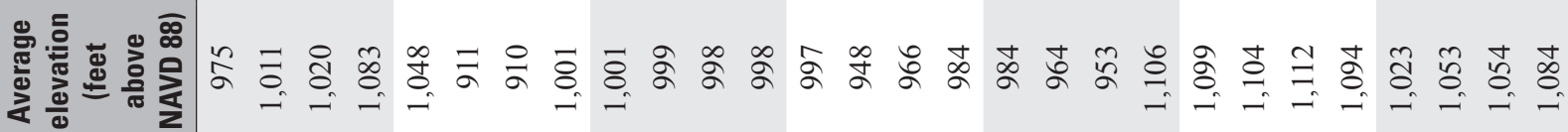

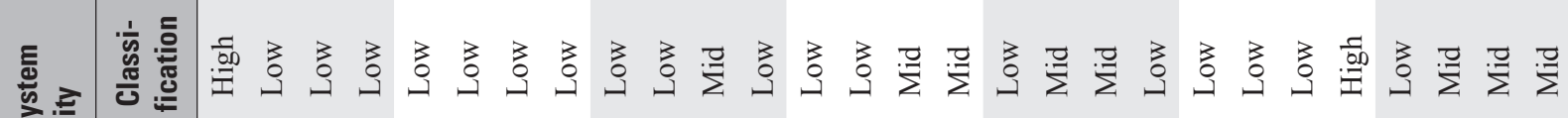

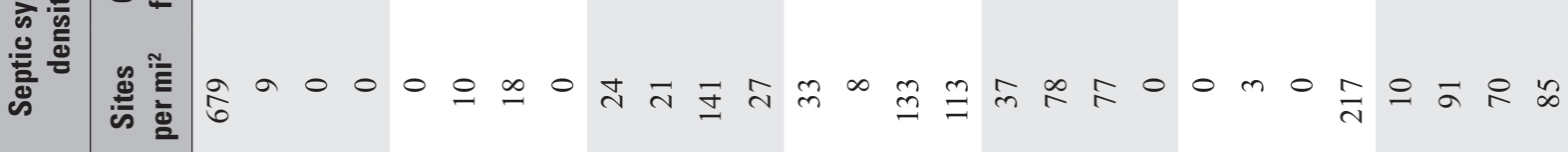

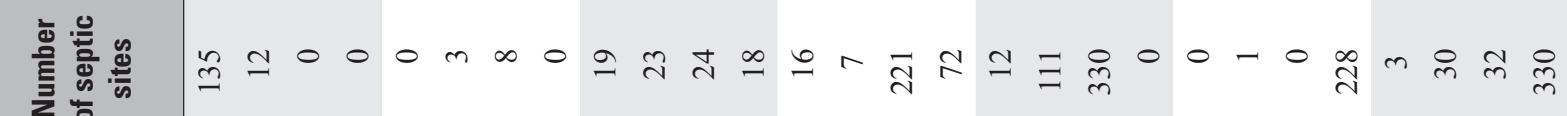
宣

营尊

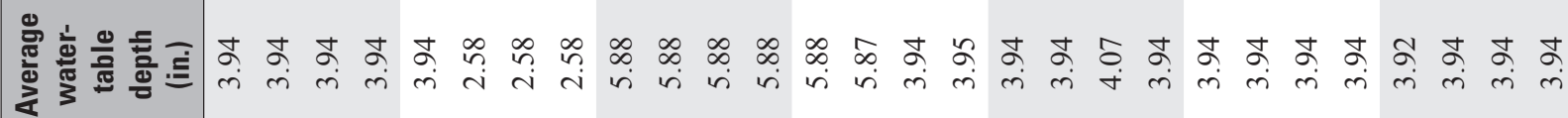

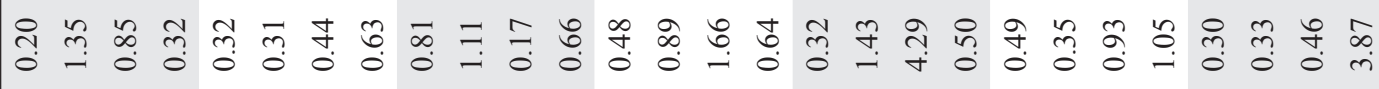




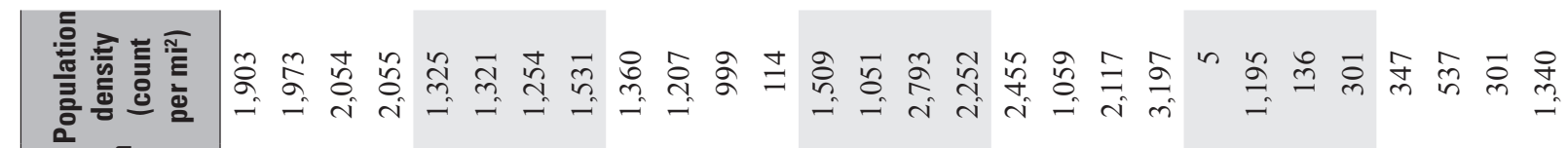

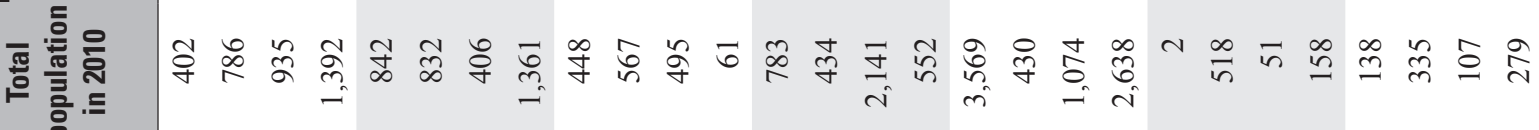
冚 을 훈을 을

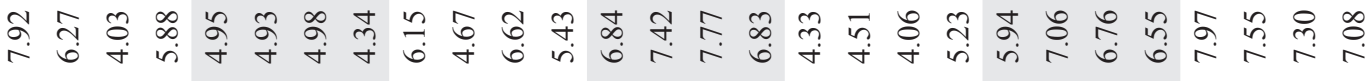

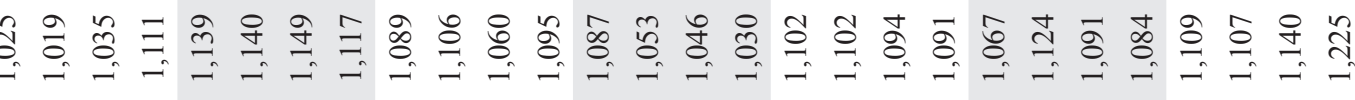

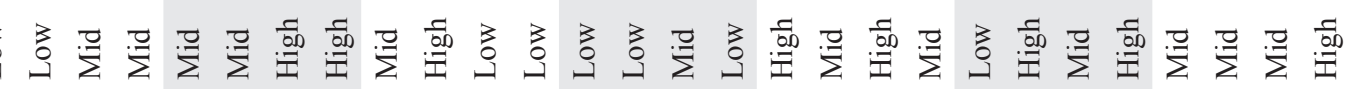

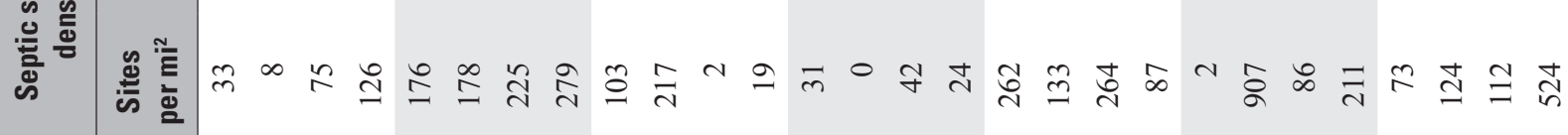

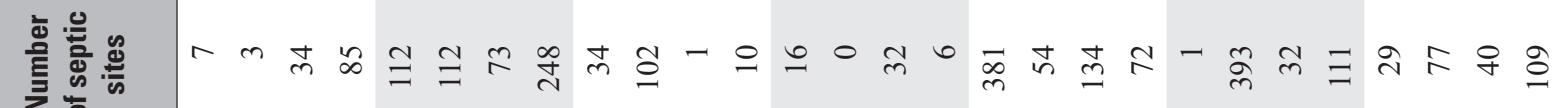
产

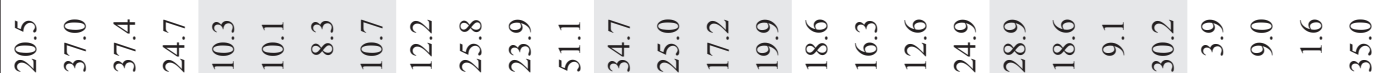
范落

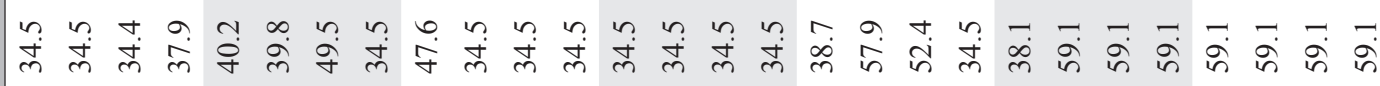

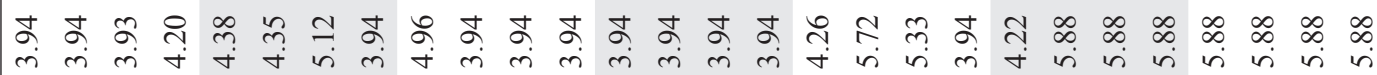

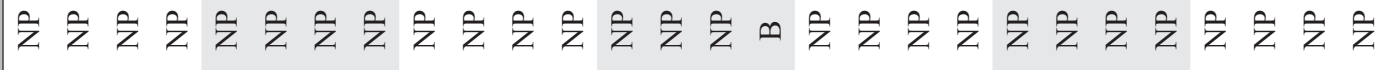




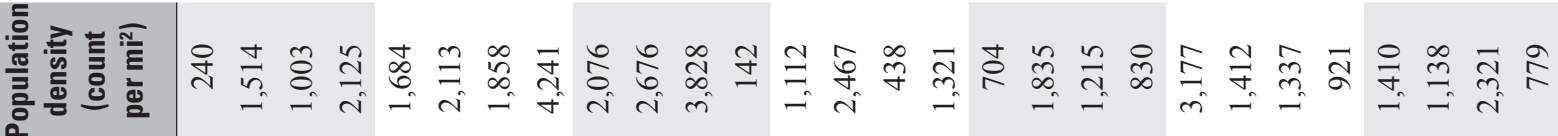

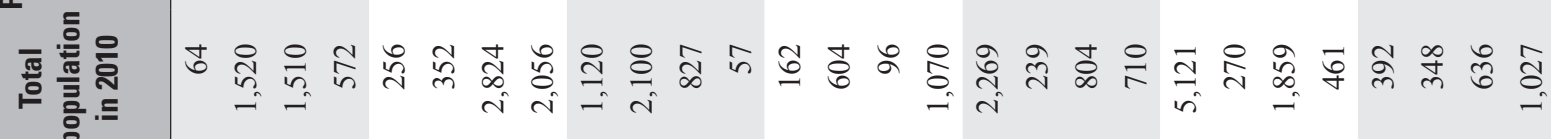

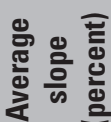

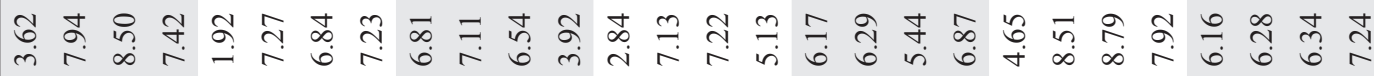

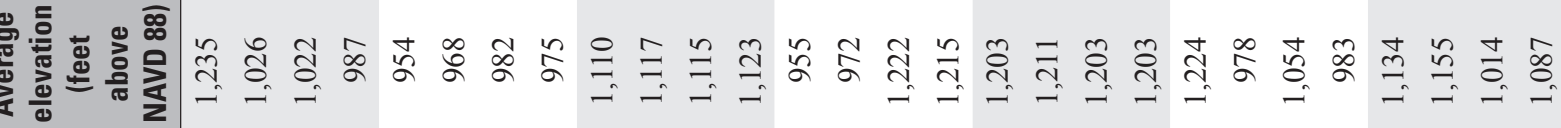

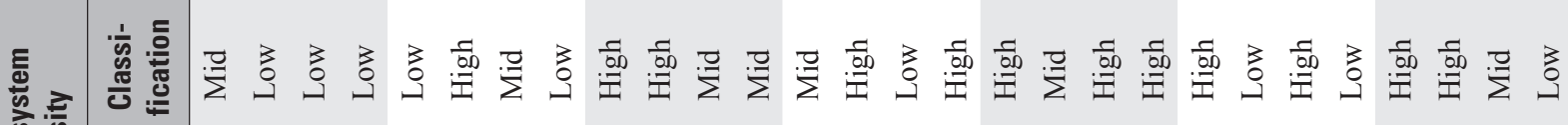

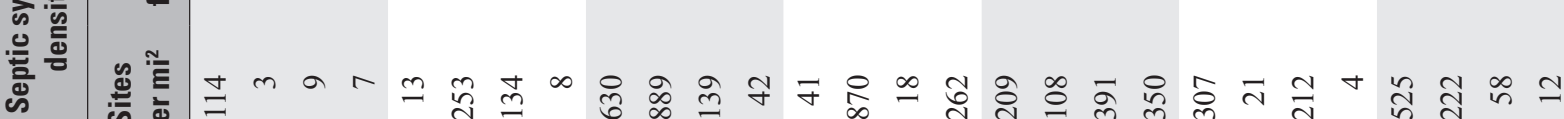
范

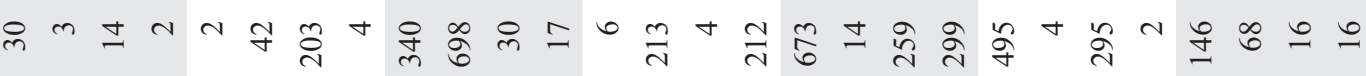

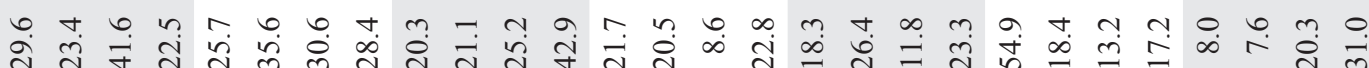

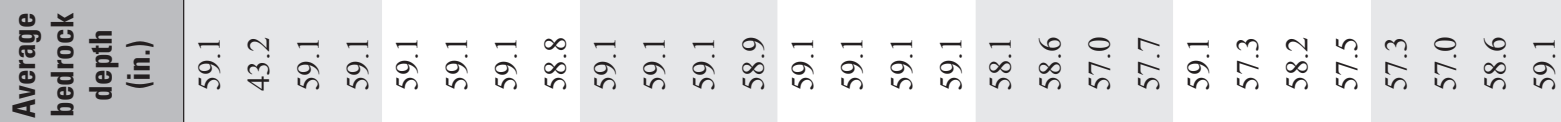

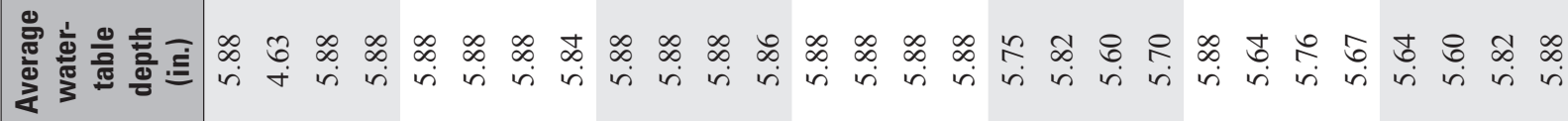

ֻุ 


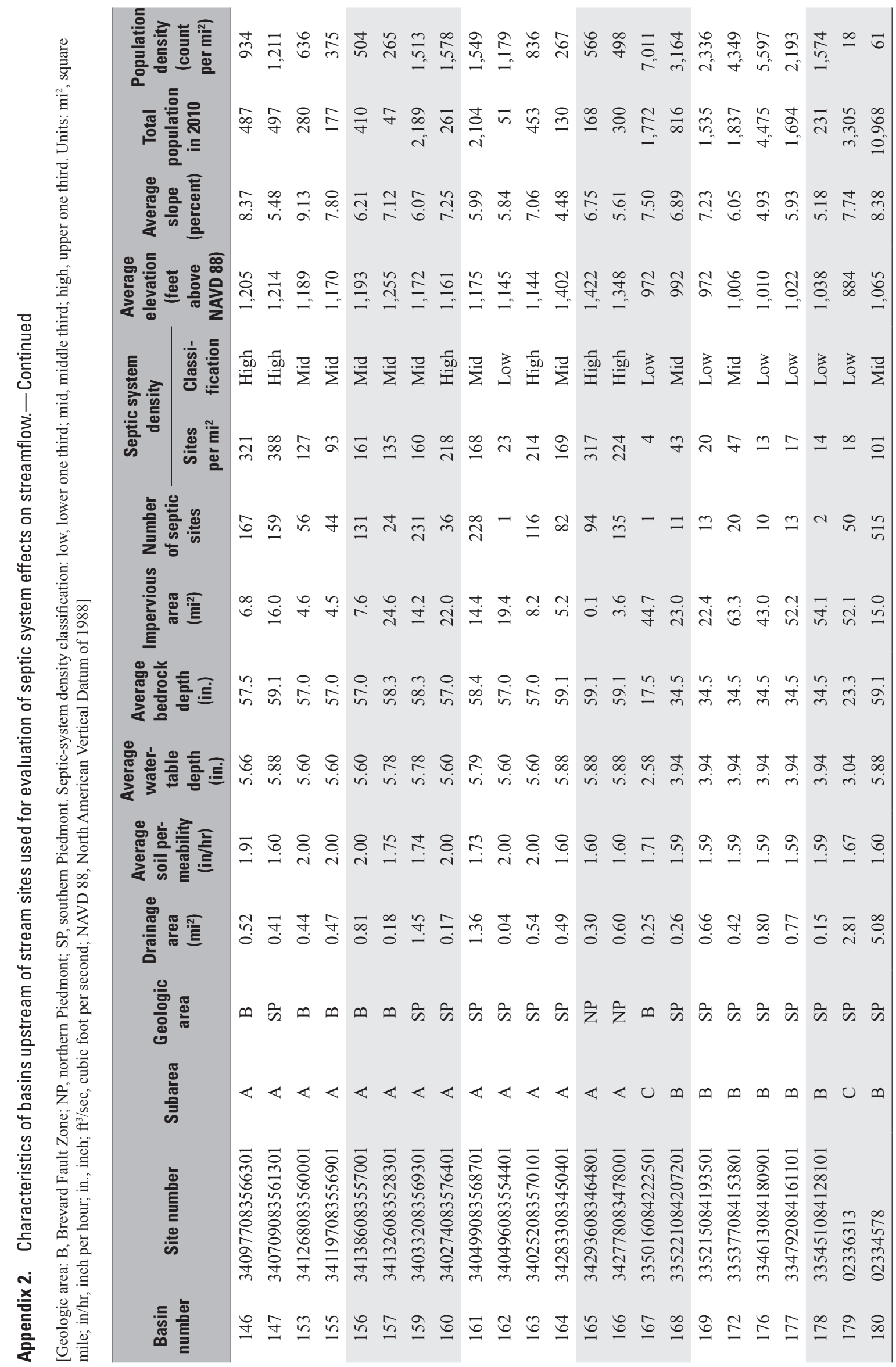


Manuscript approved July 29, 2014

Prepared by the USGS Science Publishing Network Raleigh Publishing Service Center Edited by Michael Deacon Illustrations and layout by Caryl J. Wipperfurth

For more information concerning this report, contact: Director, Georgia Water Science Center 1770 Corporate Drive, Suite 500

Norcross, GA 30093

(678) 924-6700

http://ga.water.usgs.gov/ 
